\author{
Universidade de São Paulo \\ Instituto de Física
}

\title{
Controle de Propriedades de Filmes Finos de Óxido de Alumínio Através da Assistência de Feixe Iônico
}

\author{
Thales Borrely dos Santos
}

Orientador: Prof. Dr. José Fernando Diniz Chubaci

Dissertação de mestrado apresentada ao Instituto de Física para a obtenção do título de Mestre em Ciências

Banca Examinadora:

Prof. Dr. José Fernando Diniz Chubaci (Instituto de Física - Universidade de São Paulo) Prof. Dr. Márcia de Almeida Rizzuto (Instituto de Física - Universidade de São Paulo)

Prof. Dr. Ronaldo Domingues Mansano (Escola Politécnica - Universidade de São Paulo)

São Paulo 
FICHA CATALOGRÁFICA

Preparada pelo Serviço de Biblioteca e Informação do Instituto de Física da Universidade de São Paulo

Santos, Thales Borrely dos

Controle de propriedades de filmes finos no óxido de alumínio através da assistência de feixe iônico. São Paulo, 2017.

Dissertação (Mestrado) - Universidade de São Paulo. Instituto de Física. Depto. de Física Nuclear

Orientador: Prof. Dr. José Fernando Diniz Chubaci

Área de Concentração: Física

Unitermos: 1. Filmes finos; 2. Alumina; 3. Feixe iônico; 4. Caracterização de materiais; 5 . Raios-X.

USP/IF/SBI-037/2017 
A minha Tia Ju,

por ter dado ao mundo mais do que recebeu. 



\section{Agradecimentos}

Um par de páginas não faz jus a todos aqueles que estiveram comigo até aqui. De qualquer modo, tentarei fazer meu melhor para agradecer devidamente a todos.

Agradeço ao CNPq pela bolsa de estudos.

Agradeço aos faxineiros, seguranças, técnicos e todos os demais funcionários do IFUSP que mantêm a estrutura para que eu e muitos outros possam desenvolver suas pesquisas.

Agradeço a todos os amigos do IFUSP que ajudam, de um modo ou de outro, a amenizar a labuta que é a vida acadêmica. Em particular, agradeço a Bianca Jardim Mendonça por tudo que compartilhamos, incluindo as frustações e os regozijos da pósgraduação.

Agradeço à professora e amiga Eliane Chinaglia e a seu aluno Janderson Lopes por me receberem tão bem na FEI e por me ajudarem com o AFM.

Agradeço à professora Márcia Fantini, a Antonio Carlos Silveira e a Társis Germano do laboratório de cristalografia do IFUSP por terem me disponibilizado seus equipamentos, sua atenção e seu trabalho.

Agradeço a todos os funcionários do LAMFI e ao professor Manfredo Tabacniks pelas análises de feixe iônico. Em especial, agradeço a Cleber Rodrigues por toda a atenção e por ter me ensinado muito a respeito do tratamento de dados da IBA.

Agradeço a Marina Monteiro Mendonça pela providencial ajuda com a formatação do trabalho e pela amizade.

Agradeço a Diana Taschetto por toda ajuda, atenção, incentivos e cuidados comigo e com meu trabalho. Sua ajuda foi não menos do que essencial para a confecção desta dissertação. Sua tenacidade é um exemplo que aprendi a almejar.

Agradeço ao professor Masao Matsuoka por todos os ensinamentos que dele recebi desde que cheguei ao LACIFID e por todas as vezes que me despendeu sua atenção. Este trabalho não seria possível sem sua ajuda.

Agradeço ao orientador e, principalmente, ao amigo José F. D. Chubaci. Muito obrigado por ter me recebido em seu laboratório quando eu ainda era um calouro na graduação e por ter me dado apoio contínuo desde então.

Agradeço à minha tia e madrinha Jussara Borrely Ataide, que continuou a me presentear na páscoa, no natal e no meu aniversário mesmo depois de a barba já ter me tomado o rosto e ainda que sua situação financeira fosse crítica. Tia Ju foi prova de que, 
às vezes, a vida simplesmente não é justa.

Agradeço à minha mãe, Sueli Ivone Borrely, por ter feito das tripas coração para que eu chegasse até aqui, por ter lutado como uma amazona para que eu tivesse acesso à melhor educação. Espero sempre honrar seus esforços.

Agradeço ao meu pai, Arnaldo Natal dos Santos, por priorizar meu bem-estar em detrimento de seu próprio desde que nasci. Nunca poderei retribuir suficientemente seus incontáveis gestos de amor. 
"If I have seen further, it is by standing on the shoulders of giants."

(Isaac Newton) 



\section{Resumo}

Este trabalho tem por objetivo a caracterização de filmes finos de óxido de alumínio produzidos por deposição assistida por feixe de íons $\mathrm{Ar}^{+}$. Tal caracterização consiste em estabelecer a relação entre os parâmetros de produção (energia do feixe e fluxo relativo de Ar), a composição e a estrutura dos filmes. Para tanto, utiliza-se técnicas de microscopia de força atômica, difração de raios-x, refletividade de raios-x e análise por feixe iônico. Resultados mostram que amostras produzidas à temperatura ambiente e à $450{ }^{\circ} \mathrm{C}$ são amorfas independentemente da energia do feixe iônico. Filmes formados com assistência de feixe possuem qualidade superior àqueles formados por deposição física de vapor. $\mathrm{O}$ bombardeamento de íons $\mathrm{Ar}^{+}$mostra-se capaz de controlar a concentração de hidrogênio, a estequiometria, a rugosidade, o tamanho dos grãos e a densidade dos filmes finos. Amostras com excelente qualidade - baixa rugosidade, estequiometria próxima da ideal e boa densidade - foram produzidas utilizando íons com energia dentre $300 \mathrm{eV}$ e $600 \mathrm{eV}$.

Palavras-chaves: IBAD. alumina. $\mathrm{Al}_{2} \mathrm{O}_{3}$. óxido de alumínio. filmes finos. caracterização de filmes finos. análise por feixe iônico. IAB. 



\section{Abstract}

The scope of this work is the characterization of aluminum oxide thin films produced by $\mathrm{Ar}^{+}$ion beam assisted deposition. This characterization consists in establishing the relationship between production parameters (ion beam energy and argon relative flux), structure and composition of these films. In order to undertake this task, the following techniques were used: atomic force microscopy, x-ray diffraction, x-ray reflectivity and ion beam analysis. Results show that samples produced at room temperature and at $450{ }^{\circ} \mathrm{C}$ are amorphous regardless the ion beam energy. Films grown under ion assistance have better characteristics than the ones deposited by physical vapor deposition. The ion beam bombardment is capable of controlling hydrogen concentration, stoichiometry, roughness, grain size and density of alumina samples. High quality films - flat surface and increased density films with near ideal stoichiometry - were produced with $300 \mathrm{eV}$ and $600 \mathrm{eV}$ ion beam energy.

Keywords: IBAD. ion assisted deposition. alumina. $\mathrm{Al}_{2} \mathrm{O}_{3}$. aluminum oxide. thin films. thin film characterization. ion beam analysis. IAB. 



\section{Lista de ilustrações}

Figura 1 - Processos físicos que regem a PVD [adaptado de (VENABLES; SPILLER; HANBUCKEN, 1984)]. . . . . . . . . . . . . . . .

Figura 2 - Filme sendo formado por processo IBAD. O bombardeamento iônico causa a formação de uma camada intermediária entre filme e substrato. 10

Figura 3 - Esquema de uma medida de AFM. O zoom de cor preta ilustra a interação ponta-amostra e o formato ideal da ponta [adaptado de (VOIGTLÄNDER, 2015) e (MAGONOV; WAHNGBO, 1996)]. . . . . . . . . 12

Figura 4 - Curva de força sofrida pela ponta em função da distãncia ponta-amostra. Os pontos $\mathrm{d}_{1}, \mathrm{~d}_{2}$ e $\mathrm{d}_{3}$ delimitam os modos de operação [adaptado de (CHINAGLIA, 2002)]. . . . . . . . . . . . . . . . . .

Figura 5 - Representações de artefatos resultantes do formato da ponta de prova [adaptado de (VOIGTLÄNDER, 2015)] . . . . . . . . . . . . . 15

Figura 6 - Ilustração da XRD mostrando a diferença de caminho ótico entre as parcelas $F_{1}$ e $F_{2}$ do feixe incidente. $\vec{N}$ é o vetor normal à superfície da amostra. $F_{1} / / F_{2} \ldots \ldots \ldots \ldots \ldots \ldots$

Figura 7 - Difratogramas de um cristal em pó e de um material amorfo. As intensidades não estão na mesma escala [adaptado de (CULLITY; STOCK, 2001a)]. . . . . . . . . . . . . . . . . .

Figura 8 - Feixe de luz incidindo sobre uma interface entre dois meios. Em um experimento de XRR, o meio 1 é o ar e o meio 2 é a amostra em análise. 20

Figura 9 - Exemplos de como a curva de refletividade se comporta relativamente aos parâmetros do material analisado. A espessura se relaciona com o comprimento das oscilações (A); a densidade com a amplitude e ângulo crítico (B); a rugosidade com o decaimento da curva (C). Um substrato sem filme não gera padrão de interferência (D). . . . . . . . . . . . . 23

Figura 10 - Esquema do arranjo das técnias de IBA [adaptado de (MORO, 2013)].

Figura 11 - Poder de freamento de alumínio bombardeado por partículas alfa. Na região de energia de IBA, $S_{e}>>S_{n}$. O poder de freamento nuclear é intenso na faixa de energia de alguns $\mathrm{eV}$, como a que se utiliza na IBAD [dados obtidos através de (GURBICH, 2016)] . . . . . . . . . . . . 26

Figura 12 - Colisão íon-núcleo. As linhas azuis são possíveis trajetórias dos íons. A proporção entre os anéis cinzas é a seção de choque de espalhamento [adaptado de (THORNTON; REX, 2013)] . . . . . . . . . . . . . 
Figura 13 - Razão entre seção de choque real e seção de choque Rutherford de partículas alfa incidindo em oxigênio. Em 3,0 MeV há intensa ressonância. Esta ressonância foi utilizada no presente trabalho para quantificar o oxigênio dos filmes de alumina. Estes dados foram retirados do banco de dados do National Institute of Standards and Technology. . . . . . . 29

Figura 14 - Ilustração do sistema IBAD do LACIFID. . . . . . . . . . . . . . . . 33

Figura 15 - Difratogramas da amostra E (900 eV) e do substrato de Si. Não foi medida a região entre $67^{\circ}$ e $71^{\circ}$ para evitar o intenso pico do plano (400) do Si. . . . . . . . . . . . . . . . . . . 39

Figura 16 - Difratograma de filmes produzidos com diferentes energias (esquerda) e de amostras produzidas à diferentes temperaturas (direita) . . . . . . . 40

Figura 17 - Imagens da amostra A (sem feixe iônico) obtidas através de modo contato. As nítidas linhas subparalelas indicam que a superfície da amostra não é uniforme. . . . . . . . . . . . . . . . . . . . . . . . . . 40 40

Figura 18 - Imagens obtidas por modo de contato intermitente de amostras produzidas com diferentes energias. . . . . . . . . . . . . . . . . . . 44 41

Figura 19 - Rugosidade versus energia de produção. Os pontos no gráfico representam as amostras A, B, C, D e E. . . . . . . . . . . . 43

Figura 20 - Comparação entre os tamanhos dos grãos. O aumento da ARR diminuiu os grãos (amostras B e B2). O aumento da temperatura de produção os aumentou (amostras E e E2.) . . . . . . . . . . . . 44

Figura 21 - Dados brutos de refletividade da amostra B. As descontinuidades da curva são resultado do aumento de intensidade dos raios-x e do aumento do tempo de aquisição. O aumento destes dois parâmetros experimentais serve para aumentar o sinal detectado. . . . . . . . . . . . . . .

Figura 22 - Comparação entre os dados de refletividade da amostra C e uma simulação feita com os parâmetros nominais dos filmes. . . . . . . . . . . 46

Figura 23 - Começo da curva de refletividade de várias amostras. Observa-se que O filme produzido sem assistência de feixe iônico possui ângulo crítico (e, portanto, densidade) menor que os demais. . . . . . . . . . . . . 47

Figura 24 - SLDs obtidos através de dois distintos ajustes da amostra B. Apesar de os ajustes possuírem mesma qualidade estatística $(F M=0,02)$, o ajuste 2 obteve densidades verossímeis $\left(\approx 2,75 \mathrm{~g} / \mathrm{cm}^{3}\right)$ e o ajuste 1 não. Profundidades negativas representam o substrato. . . . . . . . . . 48

Figura 25 - Ajustes de refletividade de várias amostras. As curvas foram deslocados no eixo das ordenadas para facilitar a leitura do gráfico. . . . . . . . . 49 
Figura 26 - SLD da amostra C. Todas as outras amostras apresentaram o mesmo padrão de SLD: uma região de alta densidade eletrônica próxima à superfície, variações pequenas em relação à profundidade e decaimento suave na região da interface filme-substrato. . . . . . . . . . . . . . . . 50

Figura 27 - Sinal referente à detecção de H obtido pela técnica de ERDA com feixe de partículas alfa. O aumento de energia resultou na diminuição da concentração de H. . . . . . . . . . . . . . . . . . . . . . 51

Figura 28 - Sinal referente à detecção de Ar obtido através do arranjo 4. Maiores energias de produção resultaram no aumento da saturação de Ar. . . . 52

Figura 29 - Exemplo da análise múltipla que foi realizada em todas as amostras. A curva rosa foi obtida por ERDA com partículas alfa e a curva preta por ERDA com feixe de oxigênio. As demais curvas são resultados de RBS/EBS realizados com distintos ângulos de detecção e de inclinação de amostra. . . . . . . . . . . . . . . . . . . .

Figura 30 - A curva azul é um ajuste do espectro de ERDA obtido com feixe de oxigênio. O resultado deste ajuste foi utilizado para simular espectros de outros arranjos experimentais (curvas verde e vermelha). Isto ilustra que as medidas feitas com feixe de oxigênio são imprecisas. . . . . . . . .

Figura 31 - Exemplos de perfis de profundidade obtidos pelo MultiSIMNRA. Observase que a presença de $\mathrm{H}$ não é uniforme; a concentração de $\mathrm{H}$ diminui com a energia de produção, enquanto a concentração de Ar aumenta. Detectou-se uma contaminação de 0,5 TFU de In na superfície da amostra D.

Figura 32 - Espectros de RBS/EBS das amostras A e B obtidos pelo arranjo 4. As contagens da curva preta obtidas na região de energia entre 250 U.A. e 260 U. A. indicam que a amostra A possui pequenas rachaduras. . . . .

Figura 33 - Razão O/Al das amostras A, B, C, D e E. A curva preta fornece a razão bruta. Os pontos da curva vermelha foram calculados sem levar em conta os átomos de $\mathrm{O}$ que estão ligado com $\mathrm{H}$ e supondo que estes se ligam na forma $\mathrm{H}_{2} \mathrm{O}$.

Figura 34 - Perfil de profundidade com incertezas da amostra C. A camadas entre 200 TFU e 250 TFU possui espessura menor do que a resolução das medidas e, portanto, não fornece informação confiável. . . . . . . . . .

Figura 35 - Comparação entre as rugosidade obtidas por XRR e por AFM. A ordem de grandeza das medidas é compatível, mas não há correlação aparente. 61

Figura 36 - Comparação entre as espessuras obtidas por XRR (coordenadas) e por IBA (ordenadas). A espessura em $\AA$ proveniente da IBA foi calculada assumindo a densidade resultante da XRR. . . . . . . . . . . . . . . . 



\section{Lista de tabelas}

Tabela 1 - Parâmetros do sistema IBAD utilizados na produção dos filmes de alumina 35

Tabela 2 - Parâmetros experimentais das medidas de XRR . . . . . . . . . 36

Tabela 3 - Arranjos experimentais das análises por feixes iônico . . . . . . . . . 37

Tabela 4 - Rugosidades obtidas por AFM . . . . . . . . . . . . . 42

Tabela 5 - Densidade, espessura e rugosidade obtidas através do GenX . . . . . 48

Tabela 6 - Concentrações de Ar fornecidas pelo MultiSIMNRA . . . . . . . . . . . 57 



\section{Sumário}

INTRODUÇÃO $\ldots \ldots \ldots \ldots \ldots \ldots \ldots \ldots$

1.1 Contextualização $\ldots \ldots \ldots \ldots \ldots \ldots \ldots \ldots$

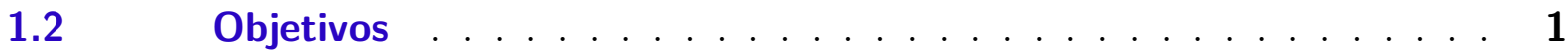

1.3 Motivações e histórico dos filmes finos de alumina . . . . . . . 2

2 TEORIA ................... 7

2.10 método de deposição assistida por feixe de íons $\ldots \ldots \ldots$

2.1.1 Deposição Física de Vapor . . . . . . . . . . . . . . . . . 7

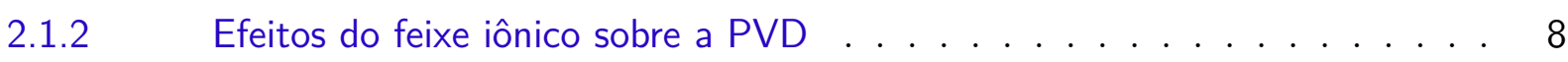

2.2 Microscopia de Força Atômica . . . . . . . . . . . . . 11

2.3 Difração de raios- $\ldots \ldots \ldots \ldots \ldots \ldots \ldots$

$2.4 \quad$ Refletividade de raios- $x \ldots \ldots \ldots \ldots$

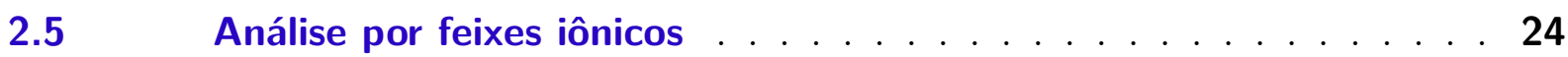

$2.5 .1 \quad$ Poder de freamento . . . . . . . . . . . . . . . . 25

2.5 .2 Seção de choque de espalhamento . . . . . . . . . . . . . . 27

2.5.3 Fator cinemático e as diferenças entre RBS, ERDA e EBS . . . . . . . 29

3 ARRANJOS E PROCEDIMENTOS EXPERIMENTAIS . . . . 33

3.1 Deposição assistida por feixe de íons . . . . . . . . . . 33

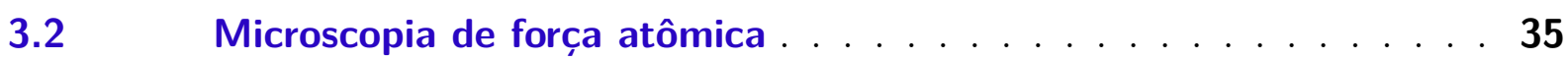

3.3 Difração de raios- $\ldots \ldots \ldots \ldots \ldots \ldots \ldots$

$3.4 \quad$ Refletividade de raios- $x \ldots \ldots \ldots \ldots$

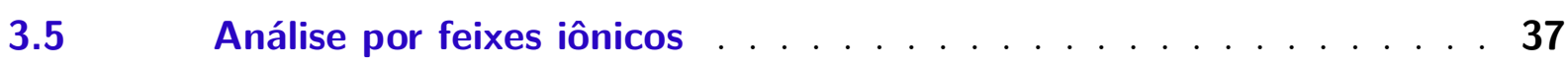

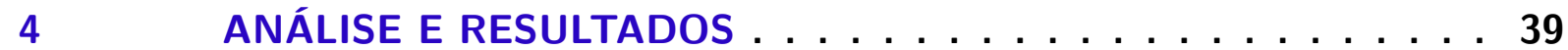

4.1 Difração de raios- $\ldots \ldots \ldots \ldots \ldots \ldots$

$4.2 \quad$ Microscopia de força atômica . . . . . . . . . . . . 40

$4.3 \quad$ Refletividade de raios- $x \ldots \ldots \ldots$. . . . . . . . . . 42

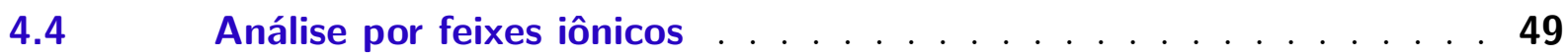

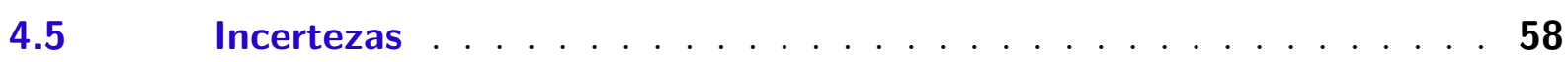

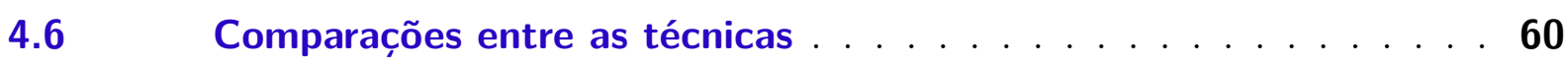

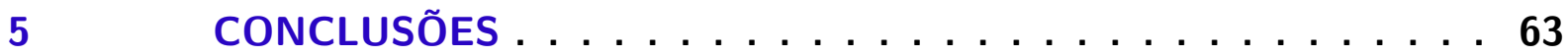

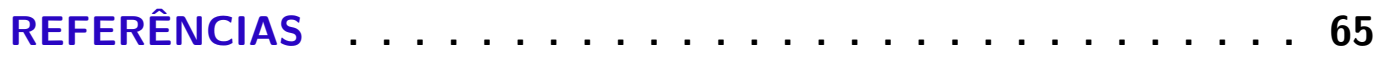





\section{Introdução}

\subsection{Contextualização}

Filmes finos são camadas de materiais sólidos com espessuras que variam entre nanômetros e micrometros e geralmente formadas sobre substratos (material de espessura muito maior que o filme). O propósito dos filmes finos é acrescentar, remover ou modificar propriedades aos/dos substratos. Os exemplos são inúmeros: camadas finas de ouro sobre anéis e brincos servem para embelezar e proteger contra oxidação; filmes de óxidos e de diamante são utilizados para proteção mecânica em ferramentas; filmes isolantes e semicondutores são acoplados para formar diversos tipos de dispositivos ópticos e eletrônicos.

A produção de filmes finos pela humanidade data de pelo menos 3000 AEC. Desde então, o conhecimento científico e tecnológico a seu respeito não parou de crescer. No século XVIII, o desenvolvimento da tecnologia de vácuo pavimentou o caminho para a proliferação de diversas técnicas para produzi-los: eletrodeposição, método sol-gel, pulverização catódica (em inglês, sputtering) e etc. Novos e sofisticados métodos de produção não param de surgir, e a comunidade científica mundial empenha esforços continuamente para dominar e compreender por completo os limites, as vantagens e as desvantagens de cada um deles (GREENE, 2014).

O princípio fundamental da produção moderna de filmes é a condensação. A maioria dos métodos atuais consiste em expor um substrato ao vapor das espécies atômicas e/ou moleculares que constituirão o filme, de modo que o vapor condensa (deposita átomos) lentamente sobre o substrato. Daí provém o fato de a expressão "produção de filmes finos" ser equivalente à "deposição de filmes finos". Um dos muitos métodos de deposição é a deposição assistida por feixe de ions (em inglês, ion beam assisted deposition, sigla IBAD). Ele se resume não somente em depositar o citado vapor - produzido fisicamente através de um sólido em vácuo -, mas também em bombardear o filme durante a deposição com um feixe iônico com energia da ordem de dezenas ou centenas de elétrons-volt. Isto é, o substrato recebe ao mesmo tempo átomos do vapor com energia cinética desprezável e íons previamente acelerados.

\subsection{Objetivos}

O objetivo do presente trabalho é determinar qual a influência de um feixe iônico de argônio na composição, no perfil de profundidade da composição, na densidade eletrônica, 
na densidade atômica e na topografia de filmes finos de óxido de alumínio (alumina) produzidos por IBAD sobre substrato de silício (100). Em primeiro plano, pretende-se determinar qual a relação entre as citadas propriedades dos filmes de alumina e a energia do feixe iônico de argônio. Em segundo plano, esta pesquisa investiga o impacto do fluxo relativo dos íons de argônio e da temperatura de deposição sobre tais propriedades. Para tanto foram utilizadas as seguintes técnicas de caracterização: microscopia de força atômica (em inglês, atomic force microscopy, sigla AFM), difração de raios-x (em inglês, $x$-ray diffraction, sigla XRD), refletividade de raios- $x$ (em inglês, $x$-ray reflectivity, sigla XRR) e análises por feixes iônicos (em inglês, ion beam analysis, sigla IBA).

\subsection{Motivações e histórico dos filmes finos de alumina}

Possivelmente o problema atual mais tecnologicamente relevante enfrentado pela ciência na área de filmes finos é o fim da Lei de Moore. Essa Lei, que será tratada adiante, trata do desenvolvimento de transístores e, portanto, de computadores. Por essa razão, pesquisas sobre filmes de óxido de alta constante dielétrica, como esta que o leitor tem em mãos, costumam ser associadas ao desenvolvimento de chips. O óxido de alumínio, porém, não é exclusivamente um isolante elétrico, ele é um material multifuncional. Suas propriedades químicas, ópticas, elétricas, térmicas e mecânicas fazem dele um candidato natural para diversas aplicações. Não é difícil rastrear estudos de filmes finos de alumina até antes da publicação do famoso On Computable Numbers de Alan Turing (TURING, 1938), artigo no qual foi concebido o computador moderno. Isto significa que a pesquisa de tal material precede a necessidade tecnológica de transístores e, portanto, de dielétricos nanométricos. Um bom exemplo dos estudos primordiais sobre filmes finos de alumina é o artigo Estrutura e crescimento de camadas finas sobre metal por oxidação no ar de Steinheil. O resumo desse trabalho está exposto ${ }^{1}$ a seguir e fornece uma ilustração dos objetivos e motivações desses estudos pioneiros:

Sabe-se que a superfície de metais simples expostos ao ar se cobre quase totalmente com uma fina camada de um composto de metal com oxigênio ou com algum outro elemento do ar. Esta camada protetora natural aumenta a resistência contra ataques mecânicos e principalmente contra ataques químicos (corrosão) e é, por isso, frequentemente reforçada artificialmente, mas se faz em outros casos, como, por exemplo, em soldas, soldagens e em contatos elétricos, muito indesejável, daí vem sua importância prática. Algumas questões pertinentes, como a taxa de formação durante longos períodos e sua relação com a composição do ar, por exemplo, são investigadas nos relatórios do Comitê de Pesquisa de Corrosão Atmosférica (Trans. Faraday SOC. Londres, 1924, 1927,

1 O trecho de Steinheil é uma tradução livre. O original foi escrito em alemão. 
1929). O presente trabalho visa se aprofundar na natureza de tais camadas, sua estrutura cristalina, os pré-requisitos para sua formação e fornecer uma contribuição para a compreensão do processo de crescimento de camadas finas e finamente cristalinas. (STEINHEIL, 1932)

O trabalho de Steinheil, motivado pelo descrito interesse tecnológico em preservar materiais metálicos, consistiu em programar experimentos e compilar resultados experimentais de corrosão de superfícies expostas a diferentes atmosferas. Seu artigo é do ano 1934, mas é possível encontrar artigos da década de 1920 que tratam de filmes finos de óxidos - como aqueles do Comitê de Pesquisa de Corrosão Atmosférica aos quais Steinheil fez referência (VERNON, 1927). À época percebeu-se que camadas finas de óxidos se formam naturalmente sobre a superfície de alguns metais. Como Steinheil coloca, a oxidação é muitas vezes indesejada. Entretanto, ela pode ser útil para, entre outras coisas, proteger o material oxidado de outras reações químicas ou de oxidações do bulk. Por exemplo, o alumínio (HUNTER; FOWLE, 1956) e o silício (MORITA et al., 1990), quando expostos ao ar, têm sua superfície rapidamente oxidada. Como essa camada de óxido não difunde para o interior do bulk, este fica protegido quimicamente da atmosfera.

Em seu artigo, Steinheil estudou as propriedades da camada de óxido natural (ou óxido nativo), que se forma sobre o alumínio metálico, através de técnicas de difração de elétrons, de transmissão de luz e de microscopia óptica. Ele concluiu que a camada nativa de alumina possuía $40 \mathrm{~nm}$ de espessuras ao completar um mês de idade e que ela poderia alcançar $400 \mathrm{~nm}$ ao expor o alumínio a temperaturas de centenas de graus Celsius. Avanços científicos mostraram que Steinheil estava errado. Hoje sabemos que os filmes de óxido de alumínio nativo possuem apenas unidades de nanômetros (EVERTSSON et al., 2015), mas seu trabalho é uma ilustração do que buscavam os pesquisadores da área entre 1920 e meados de 1950: medir as dimensões dessas camadas, quão rápido elas se formam, qual sua estrutura atômica e qual o efeito da temperatura e da atmosfera sobre elas.

Resultados experimentais como os de Steinheil provocaram tentativas de descrever a formação dos filmes teoricamente. Mott, por exemplo, sugeriu um modelo simples de difusão dos íons de alumínio através da camada de alumina nativa para prever a espessura máxima desta (MOTT, 1946). Hunter desenvolveu um método para medir a espessura do óxido através do conceito de anodização (HUNTER; FOWLE, 1954). Em seguida, produziu filmes naturalmente e anodicamente para testar o modelo de Mott, concluindo que ele possuía boa validade. Enfim, muito esforço foi empregado na primeira metade do século XX para entender os filmes nativos de alumina até que eles se estabelecessem como um protetor químico e físico regular. Contudo, suas aplicações foram além destas. A

\footnotetext{
2 Anodização é um processo para formar óxidos. Ele consiste em colocar um metal dentro de uma solução eletrolítica. Passa-se, então, uma corrente contínua na solução utilizando um catodo qualquer e o próprio metal como anodo. Ânions de oxigênio deslocam-se na direção do metal, oxidando sua superfície.
} 
segunda metade do século XX trouxe o surgimento da nanotecnologia e, consequentemente, a massiva expansão dos estudos acadêmicos de física de superfícies. Esta empreitada levou os filmes de alumina a serem aplicados em diversos outros contextos.

Alguns dizem que o marco zero da nanotecnologia é a palestra de Richard Feynman de 1959 denominada There's Plenty of Room at the Bottom (em português, "Há muito espaço no fundo") no Instituto de Tecnologia da Califórnia (TOURNEY, 2005). Outros discordam, e afirmam que o surgimento dessa área do conhecimento foi orgânico, gradual, sem ponto inicial claro (DREXLER, 1981). O fato é que o maior propulsor da nanotecnologia foi o computador moderno, inventado muito antes da referida palestra. Na década de 1930, Alan Turing concebeu a ideia da a-machine ou auto machine (posteriormente chamada de máquina de Turing), predecessora dos computadores modernos. Imediata à invenção da máquina de Turing foi a percepção de que ela teria sua funcionalidade limitada pela capacidade de reter e processar informações, isto é, seu desempenho é restringido, entre outros fatores, pela quantidade de bits que a compõem. Junto da concretização de tal máquina, portanto, surge um grande interesse no desenvolvimento de bits eficientes - leia-se de dimensões pequenas, baixo gasto energético, e grande confiabilidade - com finalidade de compor memórias de computador.

O transistor foi idealizado em 1926 por Julius Lilienfeld e concretizado em 1947 pelos físicos americanos John Bardee e Walter Brattain, abrindo um novo horizonte tecnológico na construção de circuitos elétricos. Um transistor, no contexto de um chip de computador, possui principalmente a função de switch - isto é, uma chave com duas posições -, porém, muito mais durável, confiável e energeticamente econômico do que seus predecessores, os relés e os tubos de vácuo (RIORDAN, 1998). A conveniente data de nascimento do primeiro transistor fez deste dispositivo a escolha natural para ser o principal componente dos computadores. Este novo componente eletrônico, entretanto, não foi suficiente para viabilizar computadores realmente eficientes e capazes de lidar com grandes quantidades de informação: um computador precisa de 8 bits para guardar um único caractere e o primeiro transistor possuía a dimensão de um palmo (RIORDAN, 1998)! O problema tecnológico estava dado: era necessário criar uma forma de agrupar e conectar transístores em grandes quantidades.

A solução desse problema não tardou a surgir (BROCK; LAWS, 2012). Já em 1952, Dummer propôs que em um futuro próximo os novos circuitos eletrônicos, com os recém inventados transístores, não requereriam fios de conexão, isto é, eles seriam circuitos integrados, onde os componentes são partes de um único corpo ao invés de serem elementos individuais conectados. A construção do primeiro circuito integrado é costumeiramente creditada a Jack Kilby (BROCK; LAWS, 2012). Em 1958, Kilby construiu transístores, resistores e capacitores em uma única placa de germânio, separando-os através de sulcos na placa e conectando-os com fios de ouro. 
A descrita evolução foi tão rápida que, ao fim da década de 1950, isto é, apenas 10 anos após a confecção do primeiro transístor, já estavam bem estabelecidas novas terminologias como microminiaturização, microeletrônica e circuitos integrados. Ao fim da década de 1960 os circuitos integrados tornaram-se o status quo da indústria eletrônica.

É nessa mesma década de 1960, mais precisamente no ano de 1965, que Gordon E. Moore publicou um artigo sobre o desenvolvimento de transístores em circuitos integrados (MOORE, 1965). Ao observar que a quantidade de transístores em um circuito integrado vinha dobrando a cada ano por quase 10 anos seguidos, Moore sugeriu que essa taxa de crescimento se manteria constante por mais 10 anos. Em 1975, Moore reviu seu próprio trabalho; em um segundo artigo, previu que a taxa de crescimento seria metade da anterior, ou seja, a quantidade de transístores nos circuitos integrados dobraria a cada 2 anos (MOORE, 1975). Esta última previsão tornou-se conhecida pelo nome de Lei de Moore (HUFF, 2009). Evidentemente ela não é uma lei que descreve princípios de funcionamento da natureza, como as Leis de Newton, por exemplo. A Lei de Moore é uma mera extrapolação empírica sobre o desenvolvimento de uma tecnologia específica, deficiente de bases teóricas, mas que serviu de combustível e de meta para a indústria e para a academia.

Vale ressaltar que menos de 30 anos separam a concepção do computador e o artigo de Moore. Esta incrivelmente rápida progressão não é fruto do acaso; afinal, tal período engloba a Segunda Guerra Mundial e a boa parte da Guerra Fria. Os esforços de guerra e demandas estatais relacionadas, entre outras coisas, à corrida espacial em muito envigoraram as pesquisas de computação e componentes eletrônicos (RIORDAN, 1998).

A Lei de Moore, entretanto, está se tornando obsoleta. Durante décadas os transístores foram confeccionados principalmente com $\mathrm{Si}$ e $\mathrm{SiO}_{2}$. Porém, na escala atual há previsão de comercialização de transístores de $10 \mathrm{~nm}$ ainda em 2017 (MANNERS, 2016) - transístores constituídos por esses materiais não conseguem cumprir a função de reter carga. São switchs inúteis, pois permitem a passagem de carga mesmo quando fechados (CHIEN; KARAMCHETI, 2013). Naturalmente, este fato levou laboratórios do mundo todo a pesquisar novos semicondutores para substituir o Si e materiais de alta constante dielétrica para substituir o $\mathrm{SiO}_{2}$. A alumina é um dos candidatos a substituir este último, pois atende aos requisitos de possuir alta constante dielétrica, alta temperatura de cristalização, alta resistividade, alto band gap e alta rigidez dielétrica (PHILIP, 2012).

Foi dada atenção à história de duas interessantes aplicações dos filmes de óxido de alumínio (protetor natural contra oxidação e porta de transístor) com o intuito de ilustrar que o presente trabalho é uma gota-d'água em um enorme oceano de esforços científicos, alguns dos quais nem ao menos tratam diretamente da alumina. Contudo, é possível escrever livros inteiros sobre outras modernas aplicações, que merecem aqui ser mencionadas, desse material em forma de filme fino. $\mathrm{O} \mathrm{Al}_{2} \mathrm{O}_{3}$ é utilizado como barreira de 
difusão contra água na proteção de outros óxidos como o $\mathrm{TiO}_{2}$ (SALEEM et al., 2013); sua dureza e alta condutividade térmica o tornam alvo de pesquisas em aeronáutica na função de barreira térmica em turbinas (CAO; VASSEN; STOEVER, 2004); as propriedades de sua textura, quantidade de poros e volume de poros fazem dele um bom catalisador (TRUEBA; TRASATTI, 2005); ele possui excelente dureza, estabilidade térmica e química, o que o torna costumeiramente aplicado em revestimentos antiabrasivos e dispositivos ópticos.

Apesar da vasta funcionalidade dos filmes de alumina, são escassos os relatos de sua deposição com auxílio de feixe iônico. Aqueles que existem não trataram de caracterizações quanto à presença de hidrogênio, ao perfil de profundidade da composição e da densidade (AL-ROBAEE et al., 1994; KYRYLOV; KURAPOV; SCHNEIDER, 2005; SONG et al., 2006; ZABINSKI et al., 2008); ou, quando fizeram algumas destas caracterizações, utilizaram substratos de polietileno tereftalato (PET) (EDY et al., 2013), material inadequado para muitas das citadas aplicações. As virtudes deste trabalho residem em preencher essas lacunas. Serão caracterizados os referidos aspectos de filmes de alumina produzidos sobre silício (100), este que é um dos substratos mais frequentemente estudados na academia e aplicados indústria. 


\section{Teoria}

\subsection{O método de deposição assistida por feixe de íons}

\subsubsection{Deposição Física de Vapor}

Para que seja possível descrever fisicamente a formação de filmes a partir do método IBAD, é necessário esboçar previamente os processos atomísticos que regem qualquer deposição física de vapor (sua sigla em inglês é PVD).

Uma PVD ocorre quando um material é evaporado em um ambiente evacuado dentro do qual está presente um substrato. Este vapor se expande, levando os átomos ou moléculas que o compõem a encontrar a superfície do substrato. Os átomos começam, então, a se depositar vagarosamente sobre essa superfície, formando camadas finas. Contudo, esta descrição simplória esconde a natureza complexa da deposição, que é, na realidade, constituída por processos físicos simultâneos e concorrentes (SMIDT, 1990).

Um átomo do vapor, ao se aproximar da superfície do substrato, se deposita em uma posição arbitrária dela. "Depositar", neste contexto, significa que ele está na posição vertical de energia mínima em relação à superfície. Entretanto, o valor da mínima energia não é o mesmo para todos os pontos da superfície, dado que esta é irregular em escala atômica. Tal imperfeição dá origem a um potencial superficial de energia (PSE), isto é, um potencial que varia nos pontos da superfície. Note que o ponto de deposição não é necessariamente um mínimo do PSE. Contudo, as vibrações naturais da rede do substrato podem deslocar o átomo até um ponto de mínimo do potencial. Diz-se, então, que o átomo foi adsorvido à superfície (OHRING, 2001).

Essas vibrações geram eventuais trocas de energia entre substrato e átomo adsorvido. A troca, por sua vez, gera uma probabilidade de que o átomos seja deslocado de um mínimo local até outro mínimo local do PSE. Este deslocamento é denominado difusão superficial (OHRING, 2001). A difusão é um processo estocástico regido pelo PSE: a probabilidade de um átomo sair de um ponto e chegar em outro é determinada pela estrutura do PSE. Por exemplo, uma vez que um átomo encontra o ponto de mínimo global do potencial, dificilmente ele se deslocará novamente.

O mesmo mecanismo que dá ao átomo adsorvido a probabilidade de deslocamento fornece uma probabilidade de dessorção (ou reevaporação). Isto é, o átomo pode se desprender a qualquer instante da superfície do substrato. Ambos os fenômenos, a difusão e a dessorção, possuem períodos e frequências característicos. Se frequência de difusão $\left(f_{i}\right)$ for muito maior que a frequência de dessorção $\left(f_{e}\right)$, os átomos adsorvidos se deslocarão 
bastante antes de dessorver. O inverso também é verdadeiro (VENABLES; SPILLER; HANBUCKEN, 1984).

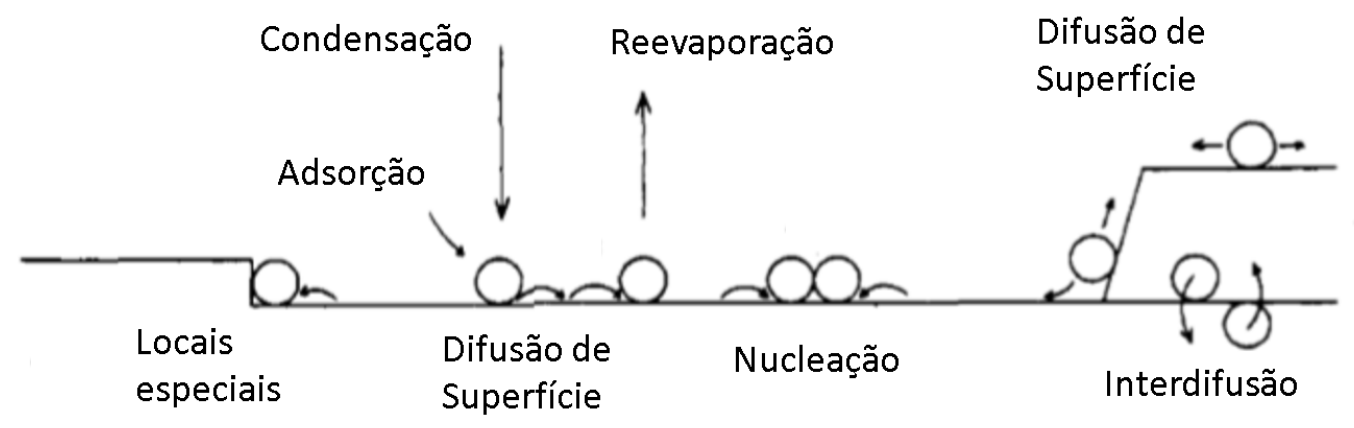

Figura 1 - Processos físicos que regem a PVD [adaptado de (VENABLES; SPILLER; HANBUCKEN, 1984)].

O processo de difusão permite que os átomos depositados eventualmente aproximemse suficientemente para se ligarem, formando agregados que têm energia total mais baixa do que os átomos individualmente somados. Por este motivo, é extremamente relevante a ordem de grandeza das frequências características: se $f_{e}>f_{i}$, os átomos adsorvidos não se deslocarão o suficiente para se encontrar e se ligar. Se $f_{e}<f_{i}$, esses agregados vão lentamente crescendo de tamanho, porém são inicialmente instáveis e acompanhados de uma probabilidade de decaimento. Quando atingem um tamanho crítico, o decaimento passa a ser energeticamente desfavorável, e os aglomerados (agora denominados núcleos supercríticos) somente receberão novos átomos (via difusão e adsorção), e não mais os perderão. Este processo é chamado de nucleação (VENABLES; SPILLER; HANBUCKEN, 1984).

É claro que os núcleos supercríticos começarão a se conectar e formarão ilhas. Essas ilhas eventualmente se distorcem abrindo espaço na superfície do substrato para novas nucleações (nucleações secundárias). A continuidade desse processo dá origem a filmes finos cujas características estruturais e morfológicas - densidade, porosidade, rugosidade e etc. - são determinadas pelas taxas de formação de ilhas, de coalescência de ilhas e de nucleação secundária (SMIDT, 1990).

\subsubsection{Efeitos do feixe iônico sobre a PVD}

O método IBAD consiste em combinar a PVD com um bombardeamento por feixe de íons com energia da ordem de dezenas ou centenas de elétrons-volt. Isto é, um feixe iônico, controlado de maneira totalmente independente da evaporação, incide sobre a superfície do filme/substrato simultaneamente à deposição do filme. A assistência dos íons traz um número de melhorias, discutidas a seguir, nas propriedades das amostras depositadas. Em contrapartida, o processo de formação torna-se tão complexo que, 40 
anos após o surgimento da técnicas IBAD, os físicos ainda não entendem por completo todos os mecanismos que a permeiam (SMIDT, 1990; WEISSMANTEL, 1976).

Quando um íon com energia menor do que $1 \mathrm{keV}$ alcança a superfície do substrato/filme, ele começa a colidir com núcleos e elétrons até perder toda sua energia e parar. Os núcleos atingidos se deslocam e colidem com outros núcleos, gerando um processo denominado cascata de colisões. Tal cascata pode ocasionar quatro fenômenos (MOHAN; KRISHNA, 1995):

(I) dessorção ou sputtering de impurezas;

(II) dessorção ou sputtering de átomos do filme e substrato;

(III) penetração e aprisionamento dos íons incidentes ou de átomos;

(IV) criação de defeitos.

A probabilidade de um átomo sofrer sputtering depende, entre outros fatores, de sua massa e de sua energia de ligação com a rede onde reside antes da colisão. Portanto, duas espécies atômicas distintas possuem probabilidades de sputtering distintas. Isso dá origem ao sputtering preferencial. Em outras palavras, um filme que possui uma dada estequiometria quando produzido por PVD muito provavelmente terá outra estequiometria se produzido com assistência por feixe iônico. Quando o feixe iônico possui baixa energia (dezenas de $\mathrm{eV}$ ) a taxa de sputtering é baixa, levando o sputtering preferencial a ser pouco relevante; e vice-versa. Vale notar o sputtering também acontece com átomos contaminantes (BIERSACK; BERG; NENDER, 1991).

A transferência de momento e energia do íon para outros átomos permite que durante a etapa inicial da deposição, quando há nenhuma ou poucas camadas atômicas de filme - átomos do vapor penetrem no substrato. Logo, a técnica IBAD tem como característica formar filmes que possuem uma região, chamada camada intermediária, onde filme e substrato se misturam (figura 2).

A cascata de colisões gera movimentação tridimensional de átomos, não exclusivamente no sentido de incidência dos íons. Isto torna a estrutura do filme mais compacta, diminuindo a quantidade de poros. Menos poros leva a menor susceptibilidade ao ambiente, aumentando a vida média dos filmes. Essa mudança microestrutural pode também modificar a densidade e rugosidade das amostras.

$\mathrm{Na}$ realidade, prever a mudança estrutural ocasionada pela assistência do feixe iônico é uma tarefa hercúlea. Deve-se ter em mente que todos os processos descritos anteriormente ocorrem simultaneamente durante a deposição. A dessorção, a adsorção, a nucleação, a cascata de colisões, a penetração de átomos e íons, o sputtering e a criação de defeito acontecem ao mesmo tempo. O seguinte exemplo ilustra a situação: um filme de fórmula molecular XY está no meio de um processo de produção IBAD; a probabilidade de 


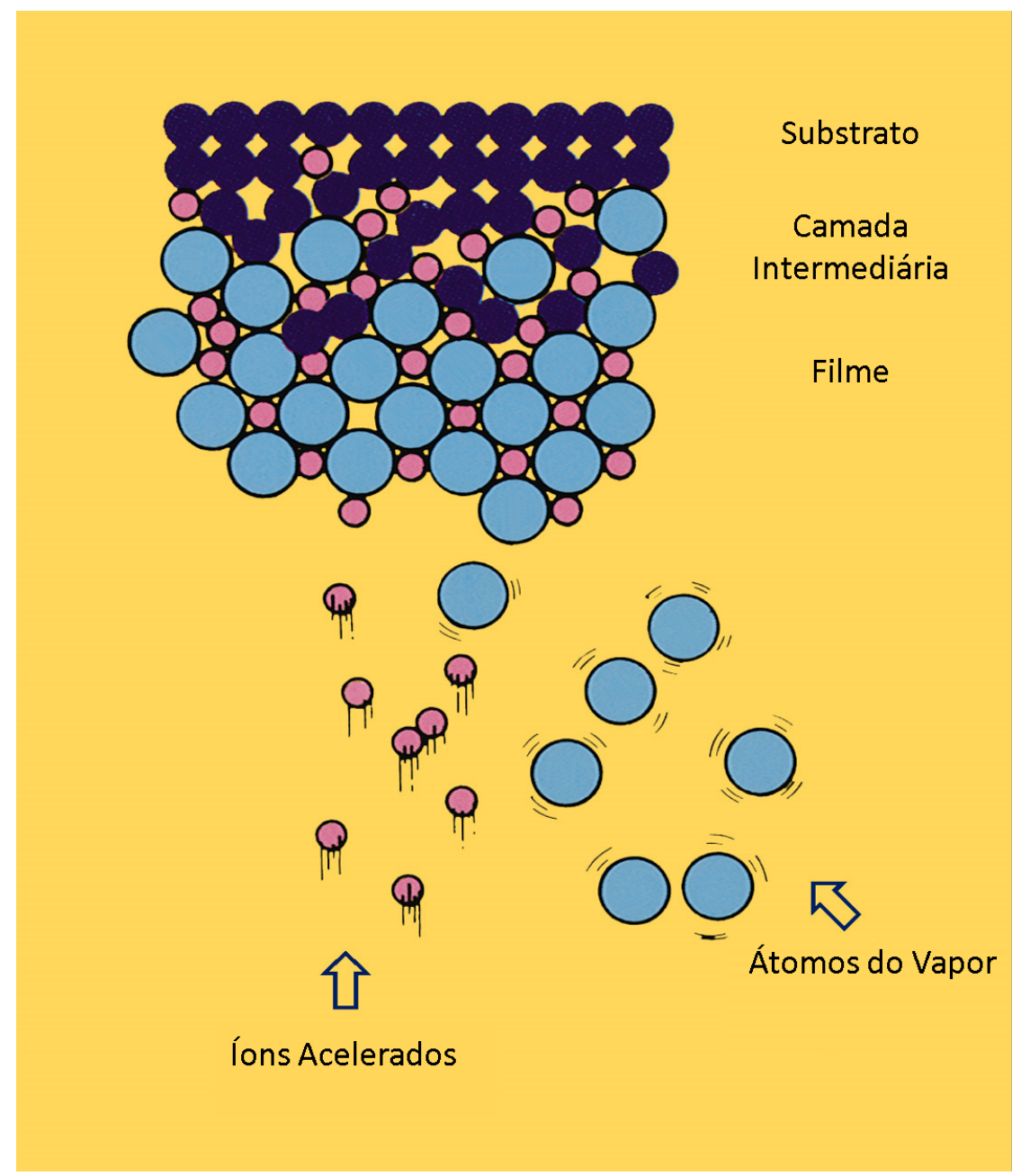

Figura 2 - Filme sendo formado por processo IBAD. O bombardeamento iônico causa a formação de uma camada intermediária entre filme e substrato.

sputtering de X é maior que a de Y. Passado um intervalo de tempo, o filme não terá mais a estequiometria correta, pois átomos $\mathrm{X}$ foram retirados em maior número do que $\mathrm{Y}$. A mudança de estequiometria altera o processo de difusão e preenchimento de vacâncias, por exemplo. As formações de ilhas e de nucleações secundárias serão alteradas. Entretanto, toda essa mudança começará a ocorrer no sentido contrário, pois o excesso de átomos $\mathrm{Y}$ diminuirá a probabilidade de sputtering de X, levando a estequiometria a se reaproximar da proporção inicial 1:1. Em síntese, a dinâmica do processo IBAD é tão complexa que não há modelo teórico atual capaz de prever plenamente o resultado da deposição (SMIDT, 1990)

Apesar de serem muitas as dificuldades para se compreender a técnica IBAD, ela é amplamente utilizada devido ao fato de criar numerosas melhorias na qualidade dos filmes e mecanismos de controle de propriedades (WEISSMANTEL, 1976; MOHAN; KRISHNA, 1995). Exemplifica-se: se o bombardeamento iônico destruir nucleações secundárias, a microestrutura do filme será composta por grandes ilhas e grandes canais; por outro lado, o bombardeamento pode aumentar a mobilidade atômica favorecendo nucleações 
secundárias; se um contaminante atmosférico é leve e com baixa energia de ligação, a colisão em cascata diminuirá sua concentração devido ao sputtering preferencial; duas espécies com frequências de difusão distintas aliadas à criação de buracos (que ocorre devido ao bombardeamento iônico) pode resultar na formação de clusters de uma das espécies; a formação de camada intermediária entre filme e substrato pode melhorar a adesão do primeiro ao segundo.

Por fim, é necessário ressaltar que todos esses processos não dependem somente da existência do feixe iônico, mas também de suas características - energia e razão de chegada (em inglês, arrival ratio, sigla ARR) entre íon e átomos do vapor. Resta aos cientistas produzir os filmes em diversas condições e caracterizá-los para tentar compreender, caso a caso, quais os processos dominantes e quais são secundários. Neste trabalho, estuda-se a relação da energia do feixe e da ARR com a densidade, rugosidade, tamanho de grãos e composição de amostras de alumina.

\subsection{Microscopia de Força Atômica}

A microscopia de força atômica ou AFM é um tipo de microscopia de varredura por ponta de prova (em inglês, scanning pobre microscopy, sigla SPM). SPM é o nome dado à classe de técnicas de análise de superfície de materiais que utilizam a interação entre uma ponta de prova móvel e átomos da superfície material para obter informações topográficas de amostras. Qualquer sistema SPM funciona através de uma ponta de prova muito afiada acoplada a um cantiléver que se desloca sobre (varre) a superfície a ser caracterizada. A varredura é controlada através de cristais piezoelétricos. Em cada ponto da varredura, a ponta recebe algum tipo de sinal (elétrons, força magnética, força elétrica e etc.) a partir do qual são inferidas característica locais da superfície.

Uma das necessidades primárias para a viabilização dos SPMs é o controle com precisão nanométrica dos movimentos da ponta de prova. Controles dessa ordem são possíveis através do fenômeno de piezoeletricidade. Este termo representa a capacidade que alguns cristais (chamados cristais piezoelétricos) têm de armazenar cargas (gerar potencial elétrico) quando submetidos a estresse mecânico. Este fenômeno também acontece inversamente: se o cristal é submetido a um potencial elétrico, ele sofre stress mecânico (dilata ou contrai). A piezoeletricidade inversa serve, entre outras coisas, para mover objetos com precisão subnanométrica. Basta acoplar tal objeto ao cristal e controlar a dilatação (ou contração) deste último através de potenciais elétricos. A piezoeletricidade é constituída por processos reversíveis. Isto é, um cristal piezoelétrico deformado por um potencial elétrico retoma seu tamanho natural quando o potencial é removido.

O AFM é o método no qual a ponta do SPM interage com os átomos do material em análise através de forças interatômicas, principalmente as de curto alcance. A capacidade de 


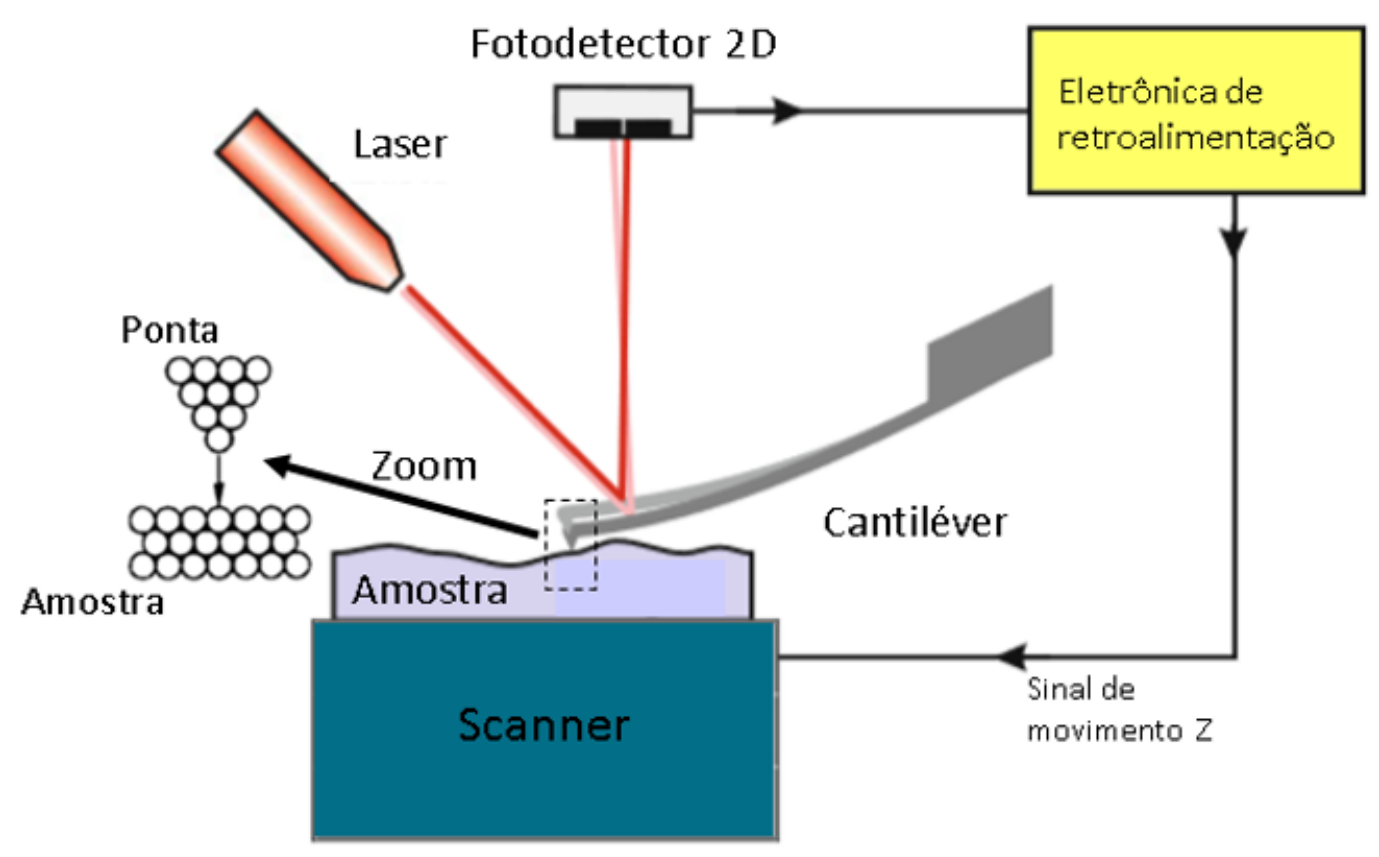

Figura 3 - Esquema de uma medida de AFM. O zoom de cor preta ilustra a interação ponta-amostra e o formato ideal da ponta [adaptado de (VOIGTLÄNDER, 2015) e (MAGONOV; WAHNGBO, 1996)].

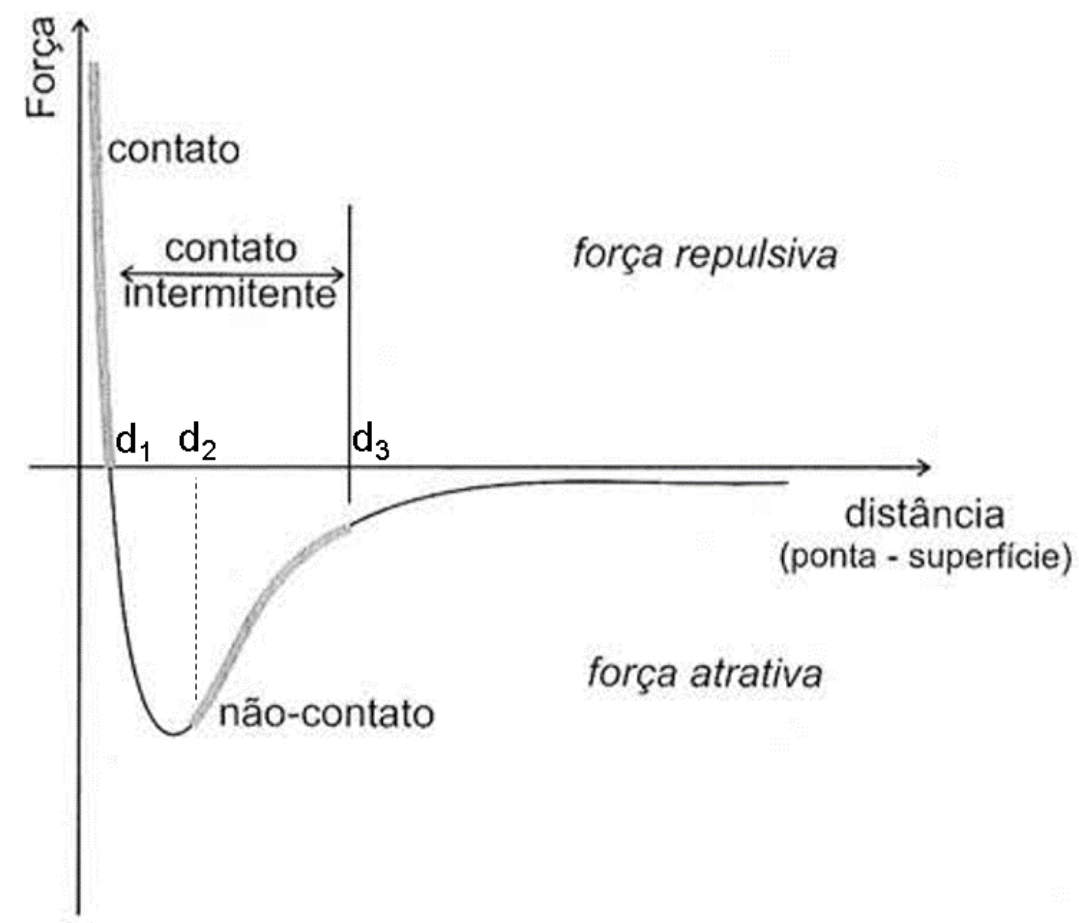

Figura 4 - Curva de força sofrida pela ponta em função da distãncia ponta-amostra. Os pontos $\mathrm{d}_{1}, \mathrm{~d}_{2}$ e $\mathrm{d}_{3}$ delimitam os modos de operação [adaptado de (CHINAGLIA, 2002)]. 
obter informações locais de superfície no AFM requer que a ponta seja afiada em escalada atômica, isto é, o perfil da ponta deve possuir uma forma triangular, cuja extremidade é idealmente constituída por um único átomo. Este átomo interage mais intensamente com a amostra do que resto da ponta (figura 3) (BINNIG; QUATE, 1986). Tal interação pode ser descrita em termos da figura 4 (CAPPELLA; DIETLER, 1999). Quando a ponta está longe da amostra, ela não sofre nenhuma força (região $d>d_{3}$ ). Ao se aproximar, ela acabará alcançando uma região dominada pela força atrativa de van der Waals $\left(d_{2}<d<d_{3}\right)$. Aproximando-se ainda mais, as nuvens eletrônicas dos átomos da ponta e da amostra começarão a se sobrepor, logo as forças repulsivas dominarão (região $d<d_{1}$ ). Quando a ponta sente a força atômica, seja ela atrativa ou repulsiva, o cantiléver sofre torque e deflete. A intensidade da deflexão depende da intensidade da força, que por sua vez depende da distância ponta-amostra. Logo, o quanto o cantiléver deflete depende indiretamente da distância ponta-amostra.

As medidas de AFM podem ser realizadas utilizando diferentes distâncias pontaamostra (BUBERT; JENNET, 2003). Quando a ponta está bem próxima da superfície, diz-se que a medida é realizada em modo contato. Este modo pode ser aplicado de duas distintas maneiras: (1) mantendo a altura da ponta constante ou (2) mantendo a deflexão (distância ponta-amostra) constante. No caso (1), enquanto a ponta é movida lateralmente para varrer a superfície, sua posição vertical nunca varia. Registra-se a variação da deflexão do cantiléver referente a cada ponto da varredura. Repare que medir a variação implica haver uma deflexão (distância ponta-amostra) inicial de referência. Como essa variação está intimamente relacionada à distância ponta-amostra, é possível inferir a altura relativa de cada ponto da superfície. No caso (2), sempre que a ponta se desloca lateralmente e a deflexão (distância ponta-amostra) é alterada, os cristais piezoelétricos são acionados para corrigir a distância ponta-amostra, mantendo a deflexão do cantiléver constante. A correção vertical é equivalente à variação de altura relativa da superfície. Logo, registrá-la em todos os pontos da superfície permite montar o mapa topográfico da amostra.

Medições de AFM também podem ser realizadas via modo de contato intermitente (JALILI; LAXMINARAYANA, 2004). Este modo de operação funciona induzindo no cantiléver um movimento oscilatório com frequência e amplitude bem definidas, de modo que a interação ponta-amostra varia entre atrativa e repulsiva. Quando a ponta oscilante sofre as forças atômicas da amostra, a amplitude de oscilação do cantiléver é alterada. Analogamente ao caso (2) do modo de contato, o microscópio deve utilizar tal alteração para corrigir a distância ponta-amostra durante a varredura, mantendo a amplitude de oscilação constante. Novamente, a correção realizada em cada ponto da varredura é armazenada para a construção de um mapa topográfico.

Há um terceiro modo de operação denominado não contato. Este modo possui o mesmo funcionamento do modo de contato intermitente, salvo pelo fato de ser realizado 
exclusivamente na região de forças atrativas. Neste trabalho foram utilizados os modos de contato e contato intermitente. Os microscópios de força atômica atuais utilizam um sistema de laser e fotodetecção para acompanhar o movimento vertical da ponta (figura 3). Este sistema incide o laser na parte superior do cantiléver, próxima à ponta de prova. A luz é refletida na direção de um fotodetector bidimensional e sensível à posição. A direção de reflexão varia conforme o cantiléver deflete, alterando o ponto iluminado do detector. O deslocamento deste ponto é, então, utilizado para calcular a deflexão do cantiléver. Tal arranjo pode medir movimentos do cantiléver com precisão de décimo de angstrom. Naturalmente, toda medida de AFM exige uma calibração prévia que consiste em posicionar o feixe refletido no centro do fotodetector.

Os dados topográficos são geralmente representados através de imagens de falsa cor, onde pontos altos são representados por cor clara e pontos baixos são representados por cor escura.

Um usuário da técnica de AFM, para bem utilizá-la, deve notar a natureza indireta dos dados obtidos e, consequentemente, das imagens construídas através dela. Como descrito, todas as informações provenientes da técnica são inferidas a partir de um sistema teórico que descreve a interação ponta-amostra. Todo sistema teórico é baseado em pressupostos. Em qualquer experimento, se alguma das suposições teóricas não corresponder à realidade experimental, as conclusões resultantes não serão acuradas. Alguns exemplos de pressupostos utilizados pela AFM são: (a) a ponta de prova possui proporções menores do que as estruturas imageadas; (b) a curvatura da ponta é menor do que as curvaturas da superfície (NYSSONEN; LANDSTEIN; COOMBS, 1991); (c) o formato afiado da ponta permite que o átomo mais proeminente interaja mais fortemente com a amostra do que o resto da ponta (WESTRA; MITCHELL; THOMSON, 1993). Caso (a), (b) ou (c) não sejam atendidos, a imagem resultante da AFM apresentará formas que não correspondem à realidade da amostra. Estas formas anômalas são denominadas artefatos.

Algumas superfícies podem possuir clusters mais estreitos do que a ponta de prova. Neste caso, (a) não será satisfeito e a imagem resultante possuirá estruturas que informam sobre a geometria da ponta, não da amostra (figura 5A). Se a ponta for arredondada e a amostra possuir formas com curvatura menor do que a própria ponta, algumas regiões da superfície não serão corretamente imageadas: (b) não será satisfeito (figura 5B). Eventualmente a ponta pode sofrer danos durante a varredura e perder sua forma triangular. Neste caso, é possível que vários de seus átomos interajam simultaneamente com a amostra, não satisfazendo (c). Novamente, isto resultará em artefatos que representam a própria ponta (figura $5 \mathrm{C}$ ). Os citados exemplos de artefatos provêm de considerações a respeito da ponta de prova. Entretanto, nem todo artefato tem esta origem. O sistema eletrônico, o scanner do microscópio e até mesmo fatores externos podem causar anomalias nas imagens. Tratar detalhadamente de todos os tipos de artefatos exigiria capítulos inteiros. Dado que 

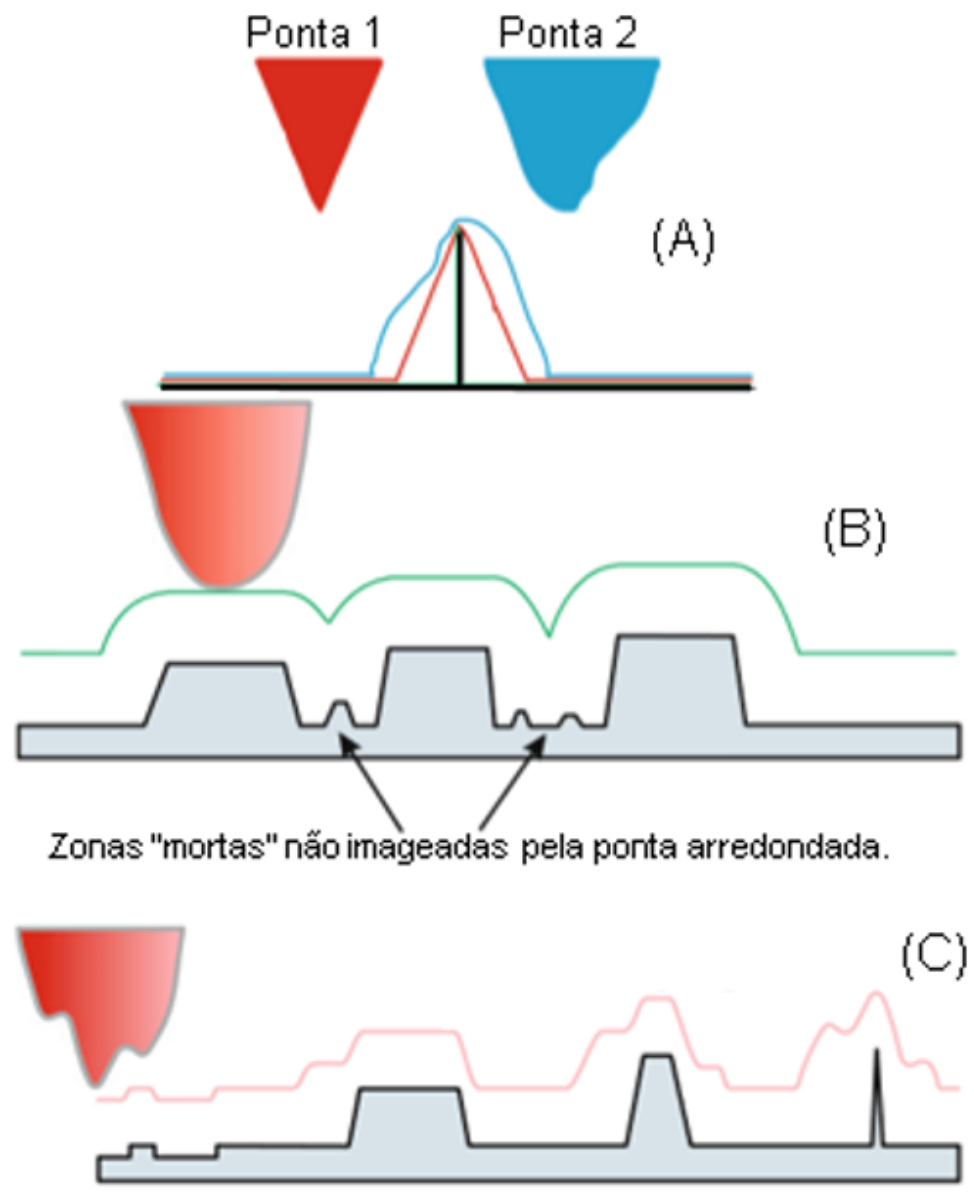

Figura 5 - Representações de artefatos resultantes do formato da ponta de prova [adaptado de (VOIGTLÄNDER, 2015)]

a AFM não compõe o cerne deste trabalho, não há espaço para discuti-los aqui.

Nesta pesquisa, a técnica de AFM foi utilizada para investigar se a assitência do feixe iônico é capaz de controlar a rugosidade e o tamanho de grãos dos filmes finos de óxido de alumínio.

\subsection{Difração de raios-X}

A difração de raios-x ou XRD é um método que utiliza a combinação entre os fenômenos de interferência e espalhamento para extrair informações sobre cristalinidade e organização atômica de um sólido. Um cristal é um sólido cujos átomos estão arranjados em um padrão que se repete no espaço. Sólidos sem estrutura atômica organizada são denominados amorfos.

A técnica consiste em incidir um feixe de raios-x monocromático sobre a superfície da amostra em análise e detectar a intensidade do feixe por ela difratado (figura 6). Os ângulos de incidência e de detecção são definidos em relação à superfície da amostra. A 
medida de intensidade difratada é realizada enquanto se varia o ângulo de incidência e mantendo o ângulo de detecção igual ao de incidência.

Qualquer estrutura periódica tridimensional constituida por elementos discretos pode ser adequadamente descrita como uma sucessão de planos paralelos habitados por tais constituientes. Isto significa que é possível pensar em cristais como objetos formados por sucessões de planos cristalinos. A figura 6 ilustra um cristal formado por linhas pontilhadas paralelas que representam os planos cristalinos; $F_{1}$ e $F_{2}$ são parcelas do feixe de raios-x que incidem e são espalhadas pelos diferentes planos. O espalhamento do feixe propaga raios-x em todas as direções, mas na imagem se representou somente as componentes espalhadas na direção do detector.

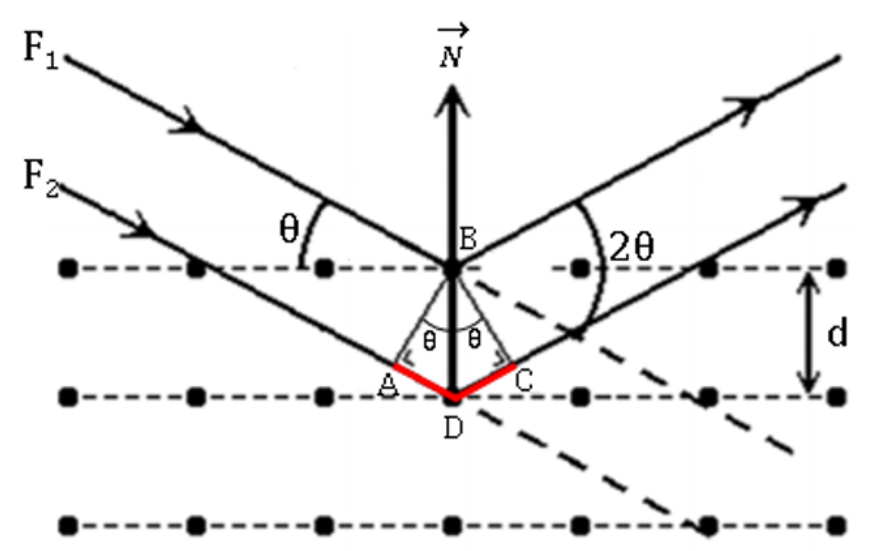

Figura 6 - Ilustração da XRD mostrando a diferença de caminho ótico entre as parcelas $F_{1}$ e $F_{2}$ do feixe incidente. $\vec{N}$ é o vetor normal à superfície da amostra. $F_{1} / /$ $F_{2}$.

$F_{1}$ e $F_{2}$ provêm da mesma fonte, mas não são espalhados pelo mesmo plano. Logo, $F_{2}$ percorre um caminho maior que $F_{1}$ até chegar no detector. Essa diferença $\Delta S$ está representada na imagem em cor vermelha. Ela é formada pela soma dos segmentos $\overline{A D}$ e $\overline{D C}$. Aplicando-se a definição de seno é possível calcular

$$
\overline{A D}=d \cdot \operatorname{sen}(\theta)
$$

onde $d$ é a distância entre os planos cristalinos.

Perceba que os triângulos $\overline{A B C}$ e $\overline{B C D}$ são idênticos. Portanto,

$$
\Delta S=2 d \cdot \operatorname{sen}(\theta)
$$

Para entender a relevância de (2.2) é necessário debater alguns aspectos da interação radiação-matéria. Quando raios-x incidem em um material, os elétrons do meio começam a interagir com o campo eletromagnético. No contexto da XRD, os raios-X (fótons) não possuem energia suficiente para arrancar elétrons mais fortemente presos aos átomos (elétrons de caroço). Se os elétrons sofrem efeito dos campos eletromagnéticos 
da onda incidente, mas não se desprendem do átomo, eles começam a oscilar, isto é, são acelerados e desacelerados repetidamente. Qualquer carga elétrica acelerada emite radiação eletromagnética, o que significa que os elétrons de caroço, ao oscilar, emitem nova radiação. As ondas eletromagnéticas assim produzidas são emitidas (espalhadas) em todas as direções, não somente na direção do detector, como na figura 6 .

Um espalhamento pode ser coerente (elástico), quando os fótons emitidos possuem a mesma energia do incidente, ou incoerente (inelástico), quando os elétrons absorvem parte da energia dos fótons. No caso da XRD, os elétrons de caroço não são ionizados e, portanto, reemitem toda a energia que absorveram. Isto configura um espalhamento coerente. A luz coerentemente espalhada mantém inalterada não somente sua energia, mas também sua frequência e seu comprimento de onda. A única coisa modificada no espalhamento elástico é a fase da onda. Entretanto, todos os elétrons alteram igualmente a fase da onda incidente em $\pi / 2$.

Se $F_{1}$ e $F_{2}$ têm sua fase igualmente alterada ao sofrer espalhamento e possuem o mesmo comprimento de onda $\lambda$, basta que $\Delta S$ seja um múltiplo de $\lambda$ para que a interferência entre eles na direção $2 \theta$ seja construtiva (CULLITY; STOCK, 2001b). Então, nessa condição:

$$
n \lambda=2 d \cdot \operatorname{sen}(\theta)
$$

onde $n$ é um inteiro maior que 0 .

A equação (2.3) é conhecida como Lei de Bragg. Em síntese, essa lei descreve em quais ângulos $2 \theta$ um cristal com distâncias interplanares $d$ difratará um feixe incidente de raios-x com comprimento de onda $\lambda$. Note que isso não significa que os elétrons espalham luz somente na direção $2 \theta$. É necessário reforçar que os elétrons fazem um espalhamento coerente da luz em todas as direções. Entretanto, a organização periódica da rede cristalina faz com que o espalhamento seja destrutivo em todas as direções, exceto $2 \theta$.

Uma estrutura cristalina não possui um único $d$. Por exemplo, a distância entre as faces laterais de um paralelepípedo reto é distinta da distância entre as faces superior e inferior. Logo, o pico de difração dado por (2.3) depende de qual face do cristal está sendo usada para o experimento. A caracterização completa de uma estrutura cristalina exige não somente encontrar $d$ a partir da medida de $2 \theta$, mas também identificar qual plano do cristal corresponde àquele $d^{1}$.

É muito comum que medidas de XRD sejam feitas com cristais em pó compactado. Explica-se a razão: o pó compactado é formado por inúmeros pequenos cristais, sendo que cada um deles tem uma face distinta voltada para a superfície da compactação. Desse modo, cada grãozinho da amostra realizará uma difração de Bragg particular, isto é, os

1 Essa identificação é feita através de uma ferramenta de classificação chamada índices de Miller (CULLITY; STOCK, 2001c). Esse assunto não será aqui apresentado, pois tais índices não foram necessários na análise de dados. 


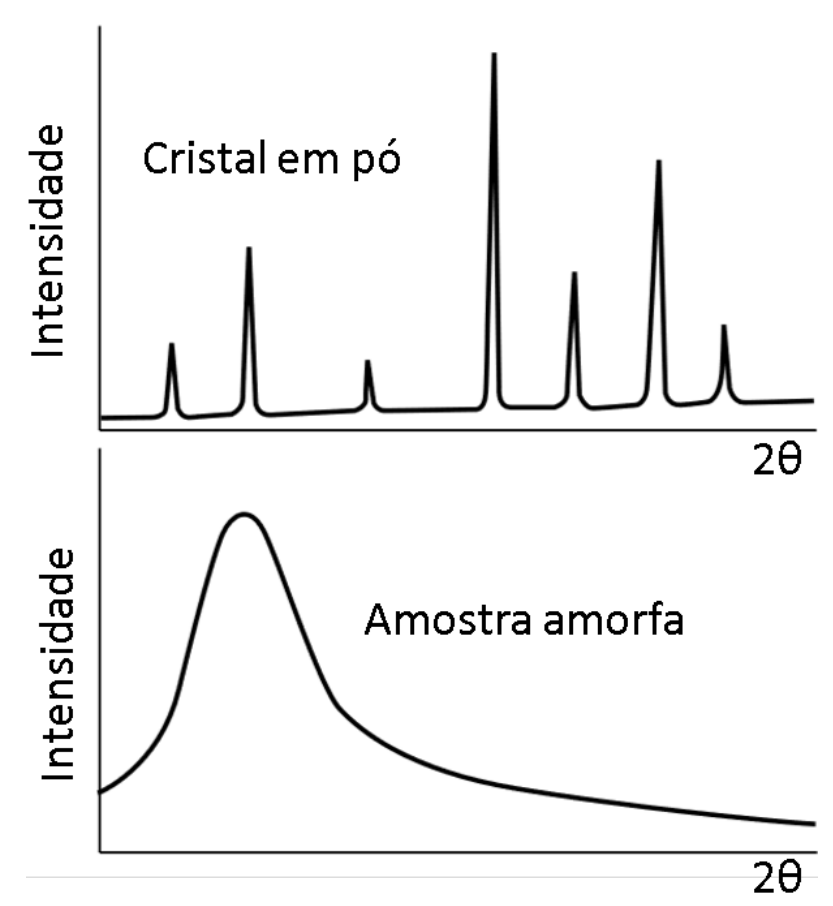

Figura 7 - Difratogramas de um cristal em pó e de um material amorfo. As intensidades não estão na mesma escala [adaptado de (CULLITY; STOCK, 2001a)].

grãos farão difração de Bragg a partir de diferentes distâncias interplanares. Dado que a quantidade de distância interplanares é, via de regra, muito menor que o número de grãos na superfície da amostra, o difratograma de uma medida em pó apresentará picos referentes a todos os planos que o cristal possuir (figura 7).

A XRD não serve somente para medir e identificar estruturas cristalinas, mas também permite analisar materiais amorfos (CULLITY; STOCK, 2001d). Ainda que sólidos amorfos não possuam arranjo atômico periódico, existe alguma ordenação em sua estrutura. As distâncias entre seus átomos não são fixas, mas também não são arbitrariamente grandes ou arbitrariamente pequenas. Existe uma distância mais provável entre os átomos que dá origem a difrações de Bragg. É claro que a menor organização dos amorfos gera picos de interferência construtiva muito menos intensos e definidos comparativamente aos cristais (figura 7).

Neste trabalho, a técnica de XRD serviu para observar o efeito do feixe iônico e da temperatura sobre a cristalização das amostras de filmes finos de alumina.

\subsection{Refletividade de raios-x}

Todo mundo experimenta cotidianamente a reflexão especular quando enxerga algum objeto utilizando um espelho ou quando vê um reflexo na superfície de uma piscina, por exemplo. Escapando de formalismos, pode-se definir a reflexão especular como $a$ 
reflexão de aparência espelhada que ocorre quando um feixe bem colimado atinge uma superfície. A ilustração desse fenômeno é idêntica à figura 6 que representa a XRD: a luz incide com um ângulo $\theta$ e é refletida com mesmo ângulo. De fato, um experimento de refletividade de raios- $\mathrm{x}$ ou XRR possui exatamente o mesmo arranjo e procedimento experimentais do XRD (LU; LEE; THOMAS, 1996), salvo por uma pequena diferença: o experimento XRR é realizado somente a baixos ângulos (com ângulo máximo da ordem de $\left.5^{\mathrm{o}}\right)$.

A análise de XRR é construída a partir da grandeza física denominada índice de refração. O índice de refração $n$ de um material é definido a razão entre a velocidade $c$, que as ondas eletromagnéticas têm no vácuo, e a velocidade $v$, que possuem quando se propagam naquele material, isto é,

$$
n=\frac{c}{v}
$$

A luz tem diferentes velocidades em diferentes meios materiais devido ao mesmo mecanismo físico de interação radiação-matéria descrito na seção de difração de raios-x. Em síntese, ao adentrar um meio material, as ondas eletromagnéticas fazem as cargas do meio oscilar. Essa oscilação gera nova radiação. Essa nova radiação se sobrepõe à primeira, gerando uma onda resultante cuja velocidade difere da que a onda tinha antes de adentrar o material. A equação (2.4) parece sugerir (erroneamente) que:

(I) O índice de refração é necessariamente maior do que o 1 para qualquer material, já que a velocidade da luz nunca pode ser maior do que $c$;

(II) O índice de refração não depende de outras características da onda eletromagnética além de sua velocidade, já que a expressão não contém nenhum outro parâmetro da onda.

A velocidade presente na fórmula é a velocidade de fase da onda. Logo, não é verdade que $n$ é sempre maior do que 1; (I) está errada. A velocidade de fase de uma onda eletromagnética não carrega informação e, portanto, segundo a teoria da relatividade restrita, pode possuir velocidade maior do que $c$.

Como descrito, o índice de refração depende da interação entre cargas e radiação eletromagnética. É claro que as oscilações realizadas pelas cargas ao interagirem com a onda dependem da frequência da onda (ou de seu comprimento da onda). Portanto, (II) também está errada.

Em particular, os materiais comumente possuem índice de refração real pouco menor do que a unidade para comprimentos de onda característicos de raios-x (YASAKA, 2010; GIBAUD; VIGNAUD, 2009a). Por isso, é conveniente expressar $n$ como

$$
n=1-\frac{\lambda^{2} r_{e} p_{e}}{2 \pi}
$$


onde $\lambda$ é o comprimento da onda, $r_{e}$ é o raio do elétron e $\rho_{e}$ é a densidade eletrônica do material. O segundo termo dessa expressão é denominado termo de dispersão e é frequentemente representado pelo símbolo $\delta$. (2.5) deixa explícita a relação entre o índice de refração, as propriedades da onda e as propriedades do material.

A interação entre as cargas e a radiação não acaba por mudar somente a velocidade da onda eletromagnética. As cargas podem absorver parte da energia contida na onda eletromagnética, diminuindo a intensidade/amplitude da onda. Note que (2.5) não possui nenhuma informação sobre a absorção da luz pelo material. Quando a absorção da luz é levada em conta, deve-se utilizar o índice de refração em sua forma complexa:

$$
n=1-\frac{\lambda^{2} r_{e} p_{e}}{2 \pi}-i \beta,
$$

onde $\beta$ é uma constante denominada termo de absorção.

De acordo com (2.5), medir o índice de refração permite obter a densidade eletrônica do material para qualquer comprimento da onda. $n$, por sua vez, pode ser obtido a partir de uma ferramenta simples: a Lei de Snell. Esta lei descreve a relação entre o ângulo de incidência e o ângulo de transmissão (refração) de uma onda eletromagnética que é transmitida de um meio a outro (figura 8). Tal relação é estabelecida a partir dos índices de refração dos meios:

$$
n_{1} \cos \left(\theta_{i}\right)=n_{2} \cos \left(\theta_{t}\right),
$$

onde o índice 1 representa o meio de onde a luz provém (ar, no contexto da XRR), 2 o meio para onde a luz é transmitida (amostra, no contexto da XRR) e $\theta$ o ângulo de incidência/transmissão.

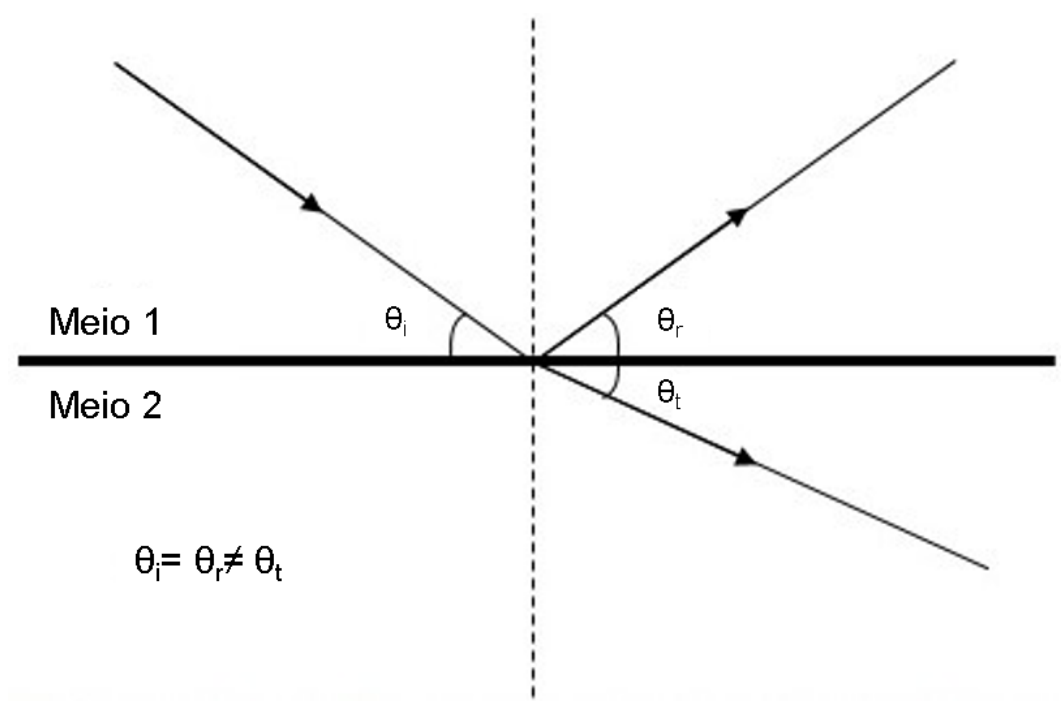

Figura 8 - Feixe de luz incidindo sobre uma interface entre dois meios. Em um experimento de XRR, o meio 1 é o ar e o meio 2 é a amostra em análise.

Se $n_{2}<n_{1}$, como acontece para os raios-x, então $\theta_{t}<\theta_{i}$. Entretanto, a luz não pode ser transmitida com ângulo $\theta_{t}<0^{\circ}$; a transmissão implica em $\theta_{t} \geq 0^{\circ}$. Logo, se $\theta_{i}$ 
for muito próximo de $0^{\circ}, \theta_{t}$ não existirá, isto é, a luz não será transmitida para o meio 2. Haverá reflexão total. Há, portanto, um ângulo crítico $\theta_{c}$ de incidência a partir do qual a luz começa a ser transmitida para o meio 2. Se $\theta_{i} \leq \theta_{c}$, não há transmissão.

Tendo em vista essas informações, entende-se porque o experimento XRR serve para obter o índice de refração (e, consequentemente, a densidade eletrônica): como descrito previamente, a XRR consiste em incidir raios-x sobre a superfície do material a ser caracterizado a partir de $\theta_{i}=0^{\circ}$ e aumentar $\theta_{i}$ enquanto se mede a intensidade da luz especularmente refletida. Quando o ângulo crítico é atingido e a luz começar a ser parcialmente transmitida para o material, a intensidade de reflexão detectada cai abruptamente e, nesse instante, todos os parâmetros da Lei de Snell são conhecidos, exceto $n_{2}\left(n_{1} \approx 1\right.$ é o índice de refração do ar, $\theta_{c}$ é o ângulo de incidência em domínio do experimentador e $\theta_{t}=0^{\circ}$ ), que poderá ser calculado a partir dos outros. Ou seja, a Lei de Snell se reduzirá a

$$
\cos \left(\theta_{c}\right)=n_{2}
$$

Se $\theta_{c}$ for pequeno, $\cos \left(\theta_{c}\right)$ pode ser escrito a partir da série de Taylor como

$$
\cos \left(\theta_{c}\right) \approx 1-\frac{\theta_{c}^{2}}{2}
$$

Substituindo (2.5) e (2.9) em (2.12):

$$
\begin{gathered}
1-\frac{\theta_{c}^{2}}{2}=1-\delta \\
\theta_{c}=\sqrt{2 \delta} \\
\theta_{c}=\sqrt{\frac{\lambda^{2} r_{e} \rho_{e}}{\pi} .}
\end{gathered}
$$

O ângulo crítico, contudo, não é parâmetro que permite obter informações estruturais das amostras. É possível obter outras características medindo a intensidade refletida para ângulo maiores que $\theta_{c}$. Para entender de onde vêm essas informações é necessário definir a grandeza refletividade. Refletividade $R$ é a razão entre a intensidade da onda refletida $I_{r}(\theta)$ e a intensidade da onda incidente $I_{i}$, isto é,

$$
R=\frac{I_{r}(\theta)}{I_{i}}
$$

A intensidade de uma onda está relacionada com o módulo ao quadrado de sua amplitude $A$. Portanto, se definirmos o coeficiente de reflexão $r$ como

$$
r=\frac{A_{r}(\theta)}{A_{i}}
$$


a refletividade poderá ser calculada assim:

$$
R=r r^{*}
$$

Note que a intensidade e a amplitude refletidas são funções de $\theta$. Para encontrar a relação entre amplitude e $\theta$ basta aplicar as condições de continuidade dos campos elétricos e magnético. Realizando este procedimento, o coeficiente de reflexão será dado por ${ }^{2}$

$$
r=\frac{\operatorname{sen}(\theta)-\sqrt{n-\cos ^{2}(\theta)}}{\operatorname{sen}(\theta)+\sqrt{n-\cos ^{2}(\theta)}} .
$$

Por fim, aplicando (2.16) em (2.15):

$$
R=\left|\frac{\theta-\sqrt{\theta^{2}-\theta_{c}^{2}-2 i \beta}}{\theta+\sqrt{\theta^{2}-\theta_{c}^{2}-2 i \beta}}\right| .
$$

Note que o numerador e o denominador da expressão (2.17) são quase idênticos, salvo por um sinal. Isto faz com que, enquanto o primeiro decresce conforme $\theta$ aumenta, o segundo cresça. Logo, $R(\theta)$ é uma função decrescente. A figura 9D esboça a aparência da curva $R(\theta)$.

O cálculo feito para encontrar $R(\theta)$ assumiu que a luz é refletida uma única vez ao encontrar a (primeira) interface entre dois meios. Isso é equivalente a dizer que o meio de transmissão é espesso o suficiente para que a luz transmitida seja totalmente absorvida antes de sair dele, antes de encontrar a (segunda) próxima interface e sofrer nova reflexão. Certamente esse não é o caso se o experimento de refletividade for feito com um filme fino. Se o filme for suficientemente fino (espessura de até algumas centenas de nanômetros), a luz transmitida através dele encontrará a interface entre o filme e seu substrato antes de ser extinta e, portanto, sofrerá nova reflexão. Neste caso, a intensidade detectada no experimento de XRR será determinada pela interferência entre o feixe refletido na primeira interface (ar-filme) e o feixe refletido na segunda interface (filme-substrato). De fato, a curva $R(\theta)$ de uma camada fina formada sobre um substrato tem a mesma aparência decrescente da expressão (2.17), porém com um padrão oscilatório de interferência (figura 9D).

O procedimento matemático para encontrar a refletividade de uma monocamada sobre um substrato é semelhante àquele feito para encontrar a expressão (2.17); afinal, a única diferença provém do fato de haver uma interface refletora a mais. Contudo, as condições de continuidade da onda eletromagnética não são suficientes para resolver o problema. É necessário utilizar também a continuidade da derivada da onda eletromagnética

2 Esse é o resultado exato do coeficiente de reflexão das componentes perpendiculares à interface. Existe diferença entre os coeficientes de reflexão das componentes paralelas e perpendiculares, entretanto para raios-x em baixos ângulos essa diferença é desprezável (GIBAUD; VIGNAUD, 2009b). 
nas interfaces. Evidentemente, todas as condições têm de ser aplicadas duas vezes: na interface filme-ar e na interface filme-substrato. Se o material analisado for composto por várias camadas, basta aplicar as condições de contorno repetidas vezes para cada interface. É claro que esse procedimento gera um sistema de equações que é mais complexo quanto maior o número de camadas. Um método simples para resolvê-lo é o método das matrizes (LEKNER, 2016), que não será tratado aqui.
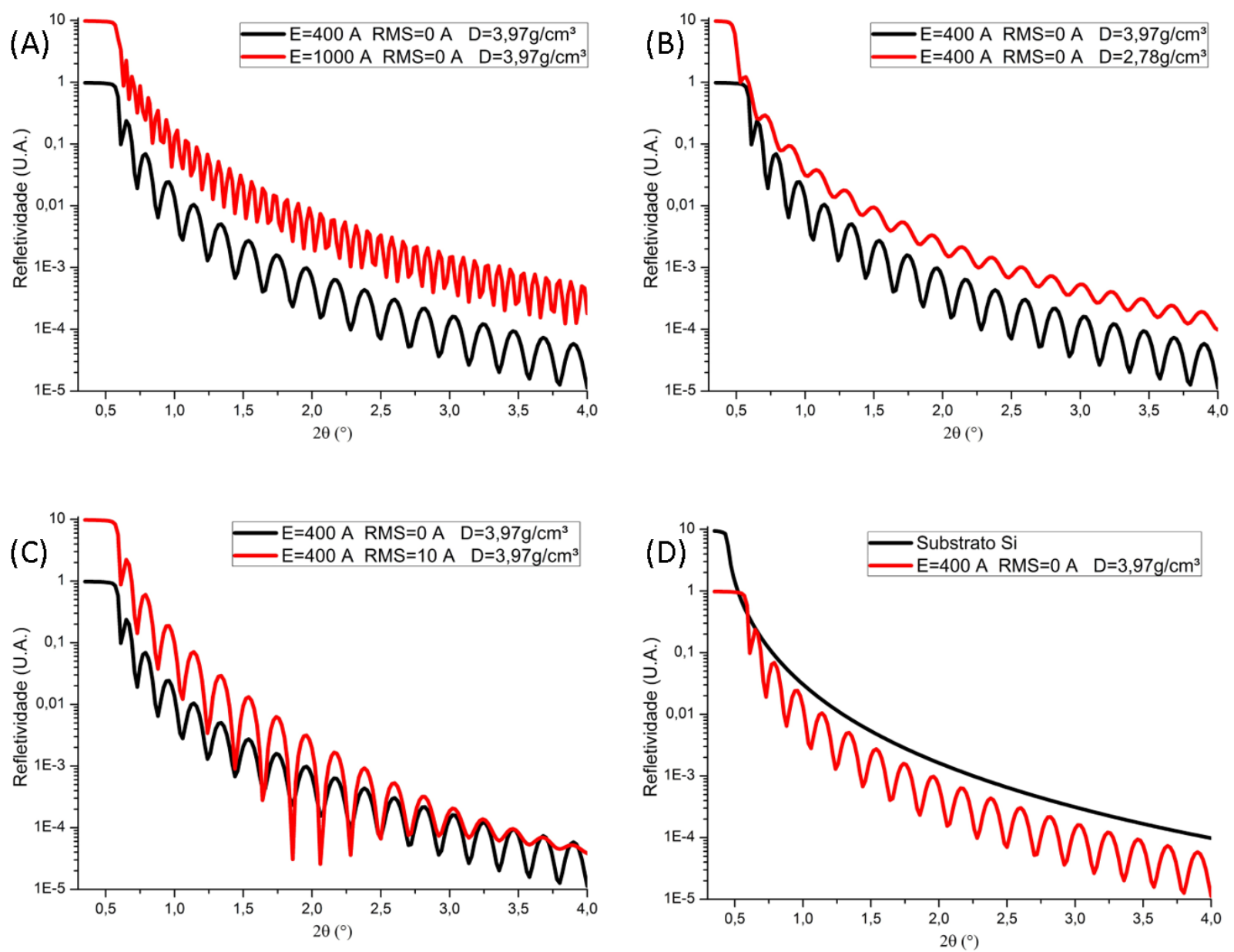

Figura 9 - Exemplos de como a curva de refletividade se comporta relativamente aos parâmetros do material analisado. A espessura se relaciona com o comprimento das oscilações (A); a densidade com a amplitude e ângulo crítico (B); a rugosidade com o decaimento da curva (C). Um substrato sem filme não gera padrão de interferência (D).

Uma vez discutido o formalismo necessário para encontrar a curva $R(\theta)$, resta saber como as características do filme influenciam nessa função. A equação (2.5) mostra que o ângulo crítico é determinado pela densidade eletrônica. A figura 9B mostra duas simulações de $R(\theta)$ calculadas a partir de filmes de alumina com mesma espessura, sem rugosidade e depositados sobre substrato de silício, porém com densidades atômicas (e eletrônicas) diferentes. Nessa figura fica clara a variação do ângulo crítico com a densidade. Entretanto, é possível notar outro fator que distingue as curvas: a amplitude de oscilação. A refletividade 
do filme com densidade próxima à do substrato possui amplitude de oscilação pequena. Quando a diferença de densidade entre filme e substrato é maior, a amplitude também é maior. Como discutido, a causa do padrão de oscilação é a descontinuidade da densidade eletrônica (descontinuidade do índice de refração). Por essa razão, a amplitude de oscilação é maior quanto maior for a diferença de densidade eletrônica entre filme e substrato. Por exemplo, no limite em que a densidade eletrônica do filme tende à densidade eletrônica do substrato, o padrão oscilatório desaparece, pois é como se o sistema filme-substrato fosse uma camada única sem descontinuidade (como na figura 9D).

$\mathrm{Na}$ figura 9A fica claro que as refletividades de duas amostras com espessuras diferentes e demais características idênticas diferem somente no comprimento da oscilação. O ângulo crítico, a amplitude de oscilação e o decaimento da curva são iguais. O que determina se o feixe refletido na primeira interface interfere construtivamente ou destrutivamente com o feixe refletido na segunda interface é a diferença de deslocamento total entre eles. Quando um filme é muito fino, a diferença de deslocamento varia pouco com o ângulo de detecção. Porém, se o filme é espesso, uma pequena variação no ângulo de detecção resulta em grande diferença de deslocamento. Essa relação entre a variação do caminho óptico e a espessura causa a diferença entre as curvas da figura 9.

A figura 9C apresenta a maneira como a rugosidade afeta a refletividade. A curva de um filme rugoso decai mais rapidamente e a forma da oscilação se altera. Isso acontece porque a reflexão especular não acontece plenamente numa interface rugosa. Uma parte do feixe incidente sofre espalhamento difuso.

A técnica de XRR serviu, neste trabalho, para encontrar o perfil de profundidade da densidade eletrônica, a espessura e a rugosidade dos filmes finos de alumina.

\subsection{Análise por feixes iônicos}

Análise por feixes iônicos ou IBA é um termo utilizado para se referir à família de técnicas de análise de materiais que utiliza bombardeamento por feixes iônicos com energia da ordem de MeV. Esses métodos servem para obter informações sobre composição e perfil de profundidade da composição em regiões próximas à superfície. Aqui serão discutidos três integrantes dessa família: retroespalhamento Rutherford (em inglês, Rutherford backscattering, sigla RBS), espectroscopia de retroespalhamento elástico (em inglês, elastic backscattering spectroscopy, sigla EBS) e análise por detecção de recuo elástico (em inglês, Elastic Recoil Analysis, sigla ERDA). As três técnicas se utilizam do mesmo arranjo experimental (figura 10): incide-se o feixe iônico sobre a amostra em análise e posiciona-se um detector de partículas em um ângulo fixo $\theta$ relativamente à trajetória inicial do feixe; o detector conta as partículas - sejam elas íons espalhados ou átomos arrancados da amostra - e mede-lhes a energia. 


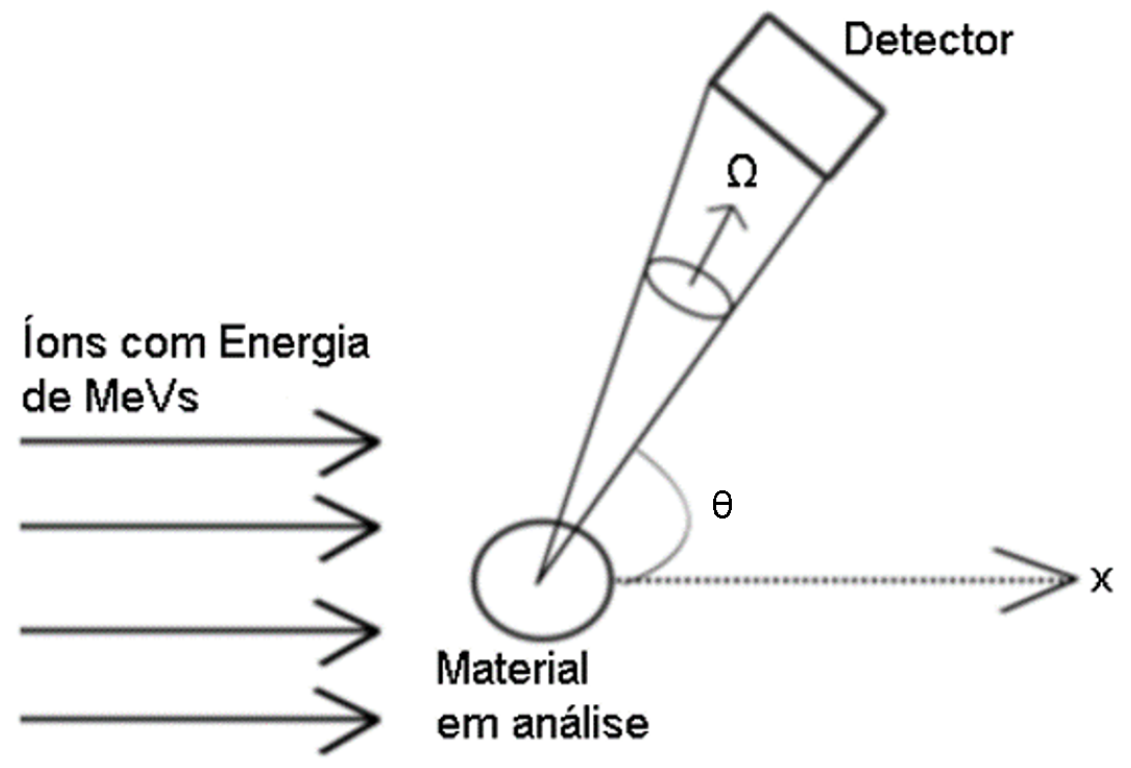

Figura 10 - Esquema do arranjo das técnias de IBA [adaptado de (MORO, 2013)].

São duas as diferenças experimentais entre os citados métodos (BUBERT; JENNET, 2003): (1) as características do feixe iônico, mais especificamente, sua energia e composição atômica; (2) o ângulo de detecção. A RBS e a EBS utilizam íons leves (tipicamente prótons ou partículas alfa) e detectam os íons retroespalhados $\left(\theta \geq 90^{\circ}\right)$ pela amostra. Diferem-se somente pela energia imposta ao feixe iônico. A ERDA utiliza íons pesados e detecta ambos, íons espalhados e partículas arrancadas da amostra, em ângulos fronteiros $\left(\theta \leq 90^{\circ}\right)$. As três técnicas se baseiam em três conceitos físicos, a saber, poder de freamento, fator cinemático e seção de choque de espalhamento. O poder de caracterização das técnicas e a diferença entre elas provêm desses três conceitos e, portanto, é necessário defini-los e discuti-los.

\subsubsection{Poder de freamento}

Quando um íon com energia da ordem de MeVs adentra um meio material, ele começa a sofrer a ação à distância da força coulombiana dos elétrons e dos núcleos do meio. Os elétrons são mais numerosos e ocupam muito mais espaço do que os núcleos. Portanto, colisões íon-elétron acontecem constantemente, enquanto colisões íon-núcleo são eventuais. Dado que um elétron é ordens de grandeza mais leve do que qualquer íon, colisões íon-elétron não levam o íon a desviar sua trajetória, apenas lhe retiram uma pequena parcela de energia. A repetição das colisões leva o íon a gradualmente perder sua energia conforme se desloca. Em outras palavras, o íon possui uma taxa $S_{e}$ de perda de energia $E$ por unidade de deslocamento causada pelos elétrons (ZIEGLER, 2004):

$$
S(E)=-\frac{\mathrm{d} E}{\mathrm{~d} x} .
$$

$S_{e}$ é denominado poder de freamento eletrônico. 
Ainda que as colisões íon-núcleo sejam eventuais, entre eles há a constante interação à distância de Coulomb. Essa interação leva o primeiro a transferir energia para o segundo. Logo, existe também um poder de freamento nuclear $S_{n}$. A soma de $S_{n}$ e $S_{e}$ é geralmente denominada poder de freamento total ou simplesmente poder de freamento (geralmente representado por $S$ ). Descrever $S$ não é uma tarefa fácil. Este é um problema com o qual a comunidade científica lida desde a descoberta da radiação no século XIX. A complexidade do problema deriva principalmente do fato de o estado de carga do íon variar durante seu deslocamento. Explica-se: um íon com velocidade muito elevada dentro de um sólido não consegue manter seus elétrons. Além disso, seu deslocamento dentro do meio material causa movimentação dos elétrons do meio, gerando polarização. Essa polarização causa ainda mais alterações no estado de carga do íon. Essa constante mudança de estado de carga altera a magnitude das forças de Coulomb, sejam elas íon-elétron ou íon-núcleo. Como todos esses processos dependem da energia (ou velocidade) do íon, $S$ é uma função de $E$.

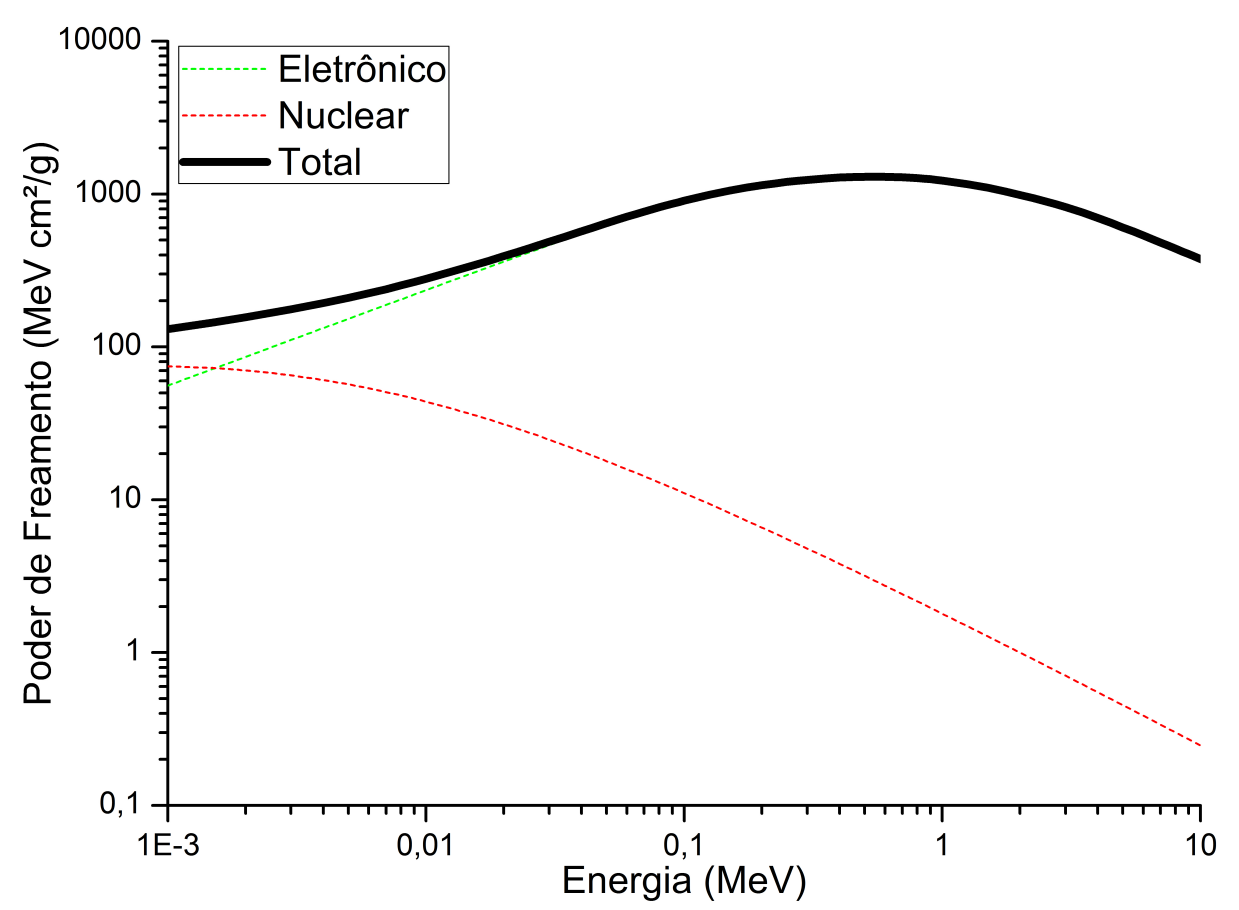

Figura 11 - Poder de freamento de alumínio bombardeado por partículas alfa. Na região de energia de IBA, $S_{e}>>S_{n}$. O poder de freamento nuclear é intenso na faixa de energia de alguns eV, como a que se utiliza na IBAD [dados obtidos através de (GURBICH, 2016)].

Até o presente, a ciência não conseguiu estabelecer um modelo estritamente teórico capaz de prever o poder de freamento de qualquer material, tamanha é a complexidade do fenômeno de freamento de partículas. O modelo utilizado neste trabalho é uma evolução 
do modelo semi-empírico ZBL (a sigla se refere aos seus criadores Ziegler, Biersack e Littmark) desenvolvida por Ziegler para seu software SRIM (sigla proveniente do nome The Stopping and Range of Ions in Matter). Este software simula a penetração de íons com energia maiores que uma centena de eV em materiais amorfos, portanto necessita de uma descrição adequada do poder de freamento (ZIEGLER, 2004).

É necessário ressaltar que, se um feixe possui energia $E_{0}$, nem todas as partículas dele colidem com energia $E_{0}$. Íons que colidirem na superfície da amostra terão energia pré-colisão $E_{0}$. No entanto, se o íon alcançar uma certa profundidade antes de colidir, sua energia pré-colisão será menor que $E_{0}$ devido ao poder de freamento. Mais precisamente, sua energia pré-colisão será

$$
E\left(x_{0}\right)=E_{0}+\int_{0}^{x_{0}} S(E) d x
$$

onde a integral no segundo termo representa o total de energia perdido até o íon alcançar a profundidade $x_{0}$ em que colide. Esse fenômeno permite distinguir partículas que colidiram em diferentes profundidades, dando às técnicas de IBA a capacidade de caracterizar não somente a composição, mas também o perfil de profundidade da composição.

\subsubsection{Seção de choque de espalhamento}

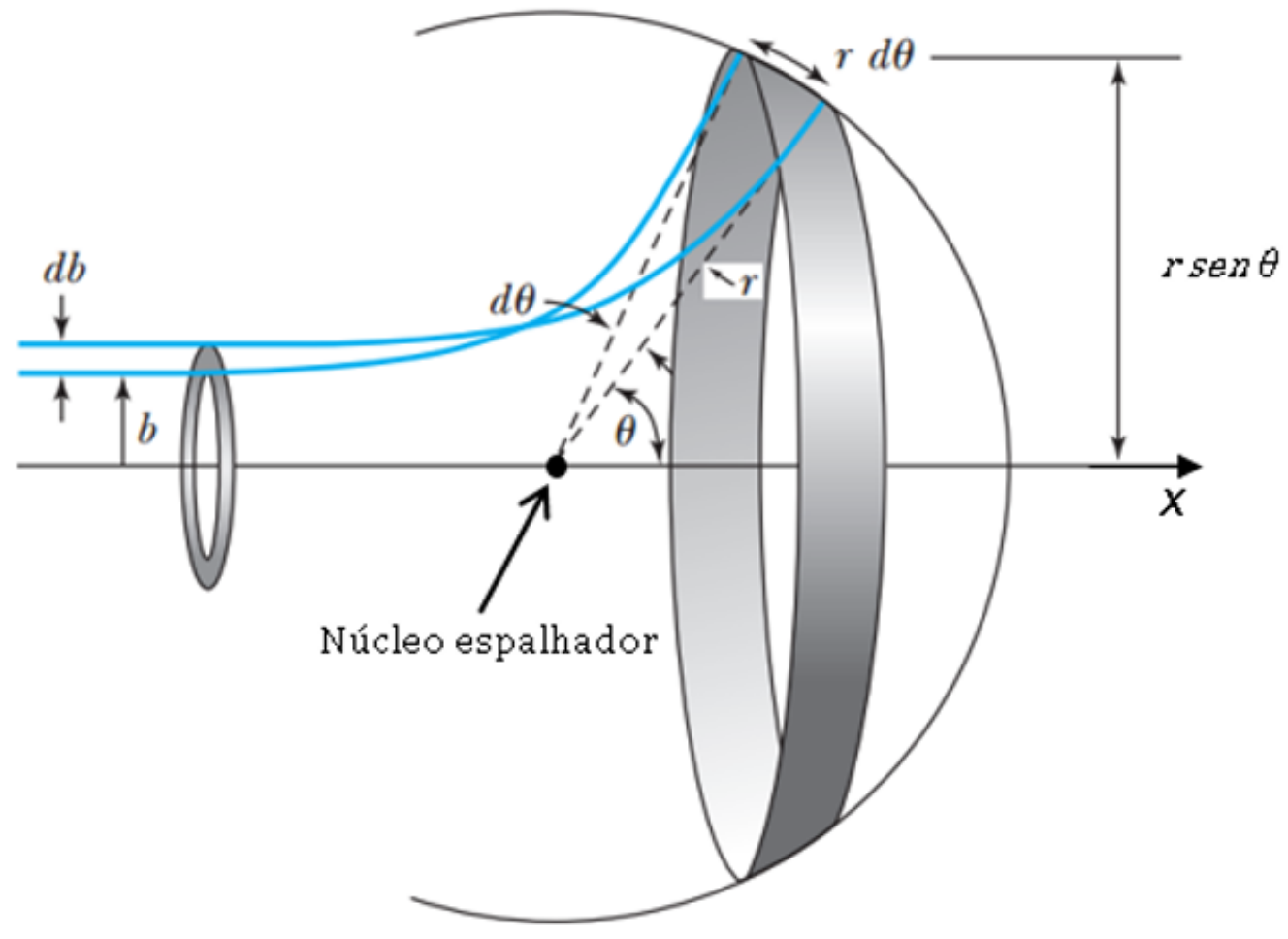

Figura 12 - Colisão íon-núcleo. As linhas azuis são possíveis trajetórias dos íons. A proporção entre os anéis cinzas é a seção de choque de espalhamento [adaptado de (THORNTON; REX, 2013)]. 
O movimento dos íons dentro da matéria não é determinado somente pelo freamento, mas também pelas colisões íon-núcleo. A figura 12 ilustra uma dessas colisões. Inicialmente o íon possui velocidade na direção $x$ e uma distância vertical $b$ em relação ao eixo $x-$ eixo que passa pelo núcleo e é paralelo à trajetória inicial do íon. $b$ se chama parâmetro de impacto. Ao se aproximar do núcleo, o íon começa a sentir o efeito da força elétrica e deflete na direção de um ângulo $\theta$ relativamente ao eixo $x$. Em $12, b+d b$ é um intervalo do parâmetro de impacto que leva os íons a serem espalhados na direção $\theta+d \theta$. A seção de choque de espalhamento $\sigma$ é definida como o fator de proporcionalidade que relaciona o anel delimitado por $d b$ com o anel delimitado por $d \theta$, isto é,

$$
2 \pi b d b=-\sigma(\theta) 2 \pi \operatorname{sen}(\theta) d \theta
$$

O sinal negativo indica que $b$ e $\theta$ possuem variação inversa: quando o primeiro cresce, o segundo decresce. Assumindo que (I) o núcleo não se move (o que é razoável quando o íon é muito mais leve do que o núcleo); e que (II) a única interação íon-núcleo é coulombiana, $b$ pode ser representado, utilizando o núcleo como referencial, pela seguinte expressão:

$$
b=\frac{Z_{1} Z_{2} e^{2}}{2 E} \cot \left(\frac{\theta}{2}\right),
$$

onde $Z$ é o número atômico, e é a carga do elétron e os índices 1 e 2 se referem ao íon e ao núcleo, respectivamente.

A equação 2.21 é deduzida relacionando a força de Coulomb com a variação do momento linear e com a conservação de momento angular (BUBERT; JENNET, 2003). Substituindo 2.21 em 2.20 conclui-se que

$$
\sigma(\theta)=\left(\frac{Z_{1} Z_{2} e^{2}}{4 E_{0}}\right)^{2} \frac{1}{\operatorname{sen}^{4}(\theta)},
$$

onde $E_{0}$ é a energia do íon pré-colisão.

A expressão 2.22 foi originalmente deduzida por Lord Rutherford em 1911. Por esta razão, $\sigma$ é comumente chamada de seção de choque de Rutherford. Contudo, nem toda colisão é bem representada pela seção de choque de Rutherford. Por exemplo, se o íon for pesado, a suposição de que nenhuma energia é transferida para o núcleo durante a colisão é inválida. Neste caso, o núcleo sofrerá recuo. A seção de choque de recuo deduzida no referencial do laboratório é

$$
\sigma(\theta)=\left(\frac{Z_{1} Z_{2} e^{2}\left[M_{1}+M_{2}\right]}{2 M_{2} E_{0}}\right)^{2} \frac{1}{\cos ^{3}(\varphi)},
$$

onde $M$ é a massa e $\varphi$ é o ângulo de recuo no referencial do laboratório.

O cálculo de Rutherford considera que ambos, íon e núcleo, são puntiformes e interagem somente via força de Coulomb. Essa suposição é inválida se algum tipo de 
interação nuclear ocorrer durante a colisão. O oxigênio, por exemplo, possui uma ressonância nuclear ao interagir com partículas alfa de 3,038 MeV. Essa ressonância aumenta a seção de choque em mais de uma ordem de grandeza (figura 13).

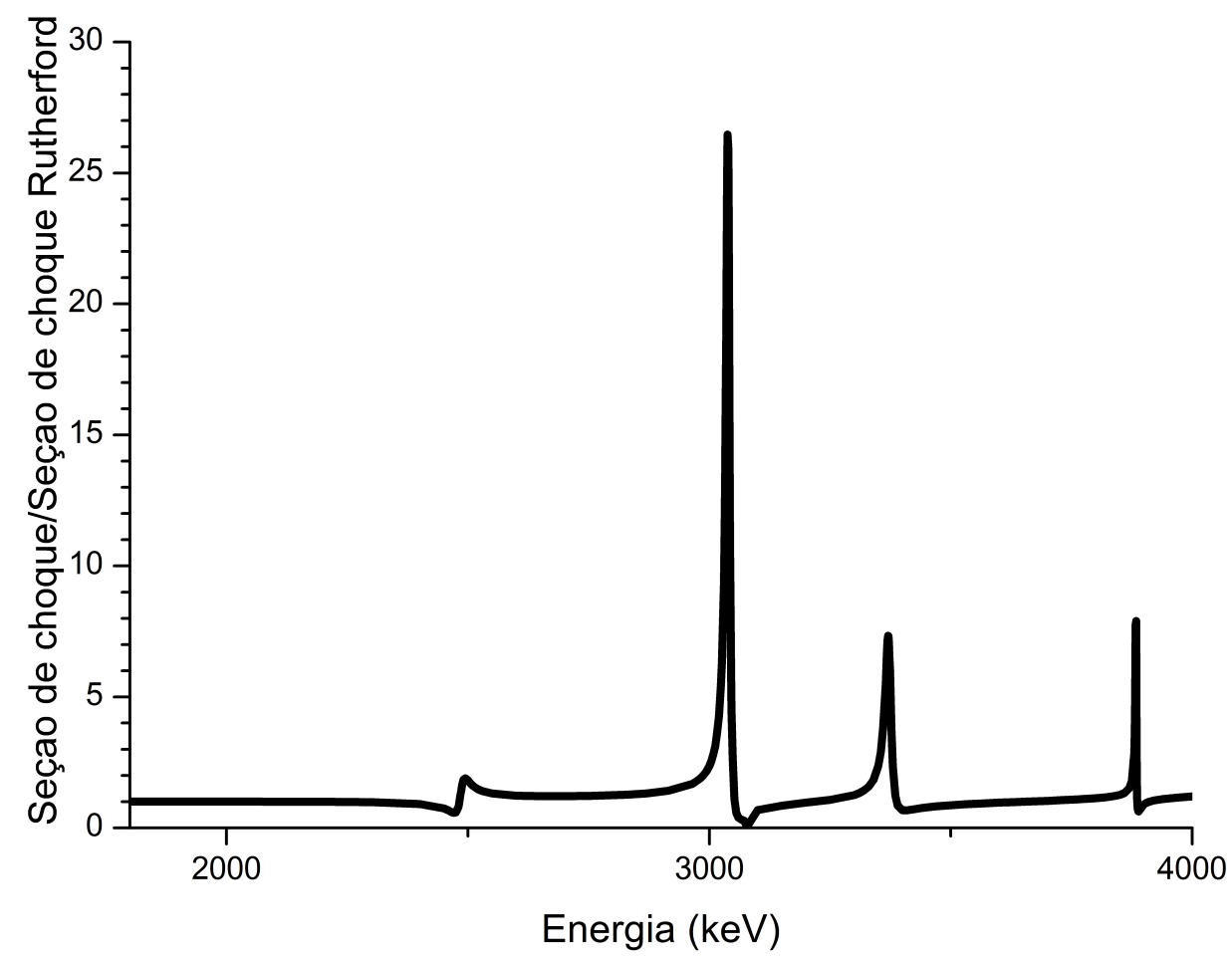

Figura 13 - Razão entre seção de choque real e seção de choque Rutherford de partículas alfa incidindo em oxigênio. Em 3,0 MeV há intensa ressonância. Esta ressonância foi utilizada no presente trabalho para quantificar o oxigênio dos filmes de alumina. Estes dados foram retirados do banco de dados do National Institute of Standards and Technology.

A quantidade $Q_{D}$ de partículas espalhadas por um elemento químico $\beta$ na direção do detector se relaciona com a seção de choque através da equação

$$
Q_{D}=\sigma(\theta) \cdot \Omega \cdot Q \cdot N_{S \beta},
$$

onde $Q$ é a quantidade de partícula incidentes, $\Omega$ é o ângulo sólido do detector e $N_{s \beta}$ é a concentração de $\beta$ em átomos/área. Dado que $\Omega$ e $Q$ são parâmetros experimentais, medir $Q_{D}$ implica na possibilidade de obter a concentração dos elementos que compõem o material em análise.

\subsubsection{Fator cinemático e as diferenças entre RBS, ERDA e EBS}

Entre os três conceitos necessários para se descrever as aqui citadas técnicas de IBA, certamente o fator cinemático $K$ é o mais simples. $K$ é definido como a fração de 
energia que o ín mantém após colidir ou, em outras palavras, a razão entre a energia do ion pós-colisão $\left(E_{1}\right)$ e pré-colisão $\left(E_{0}\right)$. $K$ é facilmente dedutível através das equações de conservação do momento linear e da energia (BUBERT; JENNET, 2003). Ele depende somente das massas das partículas colidentes e do ângulo de espalhamento do íon:

$$
K=\frac{E_{1}}{E_{0}}=\left[\frac{\left(M_{2}^{2}-M_{1}^{2} \operatorname{sen}^{2} \theta\right)^{2}+M_{1} \cos \theta}{M_{2}+M_{1}}\right]^{2} .
$$

O fator cinemático é aquele que permite aos métodos de feixe iônico determinar a composição das amostras. Em um experimento RBS/ERDA/EBS, $E_{0}$ e $M_{1}$ são características do feixe conhecidas pelo experimentador, enquanto $E_{1}$ e $\theta$ são dados medidos pelo detector. Isto posto, $M_{2}$, que representa a composição da amostra, pode ser obtido, pois é a única incógnita de (2.25). Analogamente à (2.25), é possível definir um fator cinemático de recuo $K^{\prime}$ :

$$
K^{\prime}=\frac{E_{2}}{E_{0}}=\frac{4 M_{1} M_{2}}{\left(M_{1}+M_{2}\right)^{2}} \cos ^{2}(\varphi) .
$$

Em resumo, foi discutido que (a) o poder de freamento fornece a resolução de profundidade, (b) a seção de choque fornece a estequiometria e (c) o fator cinemático fornece a composição. Resta entender como esses três conceitos delimitam as técnicas RBS, ERDA e EBS.

Como foi dito anteriormente, as técnicas RBS e EBS medem o retroespalhamento de íons leves (partículas alpha e prótons). A equação (2.25) mostra que o recuo de átomos da amostra acontece somente para $\theta<90^{\circ}$. Por isso, medidas de retroespalhamento possuem a vantagem de detectar somente partículas provenientes do feixe, não da amostra. Isto facilita muito a análise de dados. Em contrapartida, elementos leves são indetectáveis via RBS e EBS, pois não têm massa suficiente para retroespalhar os íons. Além disso, o freamento de íons leves é muito baixo. Consequentemente, a resolução de profundidade em medidas RBS e EBS é pequena (dezenas de nanômetros). A diferença entre essas duas técnicas reside somente na seção de choque. A RBS se faz com energias onde a seção de choque tem comportamento Rutherford. A EBS utiliza regiões de energia onde a seção de choque não é Rutherford, geralmente aproveitando platôs ou picos ressonâncias. Evidentemente, a EBS é possível somente em casos particulares nos quais é possível escolher um feixe iônico que interage elasticamente com átomos da amostra.

A ERDA utiliza íons pesados como oxigênio e cloro, por exemplo. Como citado na seção anterior, a colisão dessas partículas com grande massa ocasiona o recuo dos núcleos do material em análise. Consequentemente, chegam no detector - lembrando que, nesse caso, o ângulo de detecção tem de ser menor que $90^{\circ}$ - não somente partículas do feixe, mas também átomos que compõem a amostra. Este fato dificulta a análise por ERDA, porque sinais de recuo e de espalhamento se misturam no espectro. Por outro lado, há a vantagem de quantificar elementos leves na amostra. Partículas pesadas sofrem muito 
mais freamento do que partículas alfa ou prótons. Portanto, a ERDA possui resolução de profundidade várias vezes maior do que a RBS e a EBS.

Nesta pesquisa, as análises por feixes iônicos serviram o propósito de quantificar a presença de oxigênio, alumínio, argônio, silício, hidrogênio e eventuais contaminantes nas amostras de alumina. Foram estabelecidas relações entre os parâmetros de produção dos filmes e os perfis de profundidade de concentração de cada um desses elementos. Pormenores de como as três técnicas foram combinadas para alcançar este objetivo estão descritas na seção de análise. 



\section{Arranjos e procedimentos experimentais}

\subsection{Deposição assistida por feixe de íons}

O sistema de deposição assistida por feixe de íons utilizado neste trabalho pertence ao Laboratório de Cristais Iônicos Filmes e Datação (LACIFID) do Instituto de Física da Universidade de São Paulo (IFUSP). Ele consiste em uma câmara de vácuo cilíndrica de aço inox com aproximadamente $1 \mathrm{~m}$ de altura e $60 \mathrm{~cm}$ de diâmetro. Essa câmara está equipada com uma evaporadora por feixe de elétrons, uma fonte iônica do tipo kaufman, um oscilador de quartzo para medir de taxa de deposição, um copo de faraday para medir a corrente de íons, dois suportes de substrato - um deles equipado com um termopar e com uma resistência, que permite aquecimento por efeito joule -, dois obturadores para blindar os dois suportes, uma bomba mecânica de pré-vácuo, uma bomba criogênica de alto vácuo e dois medidores de pressão, um penning e outro pirani.

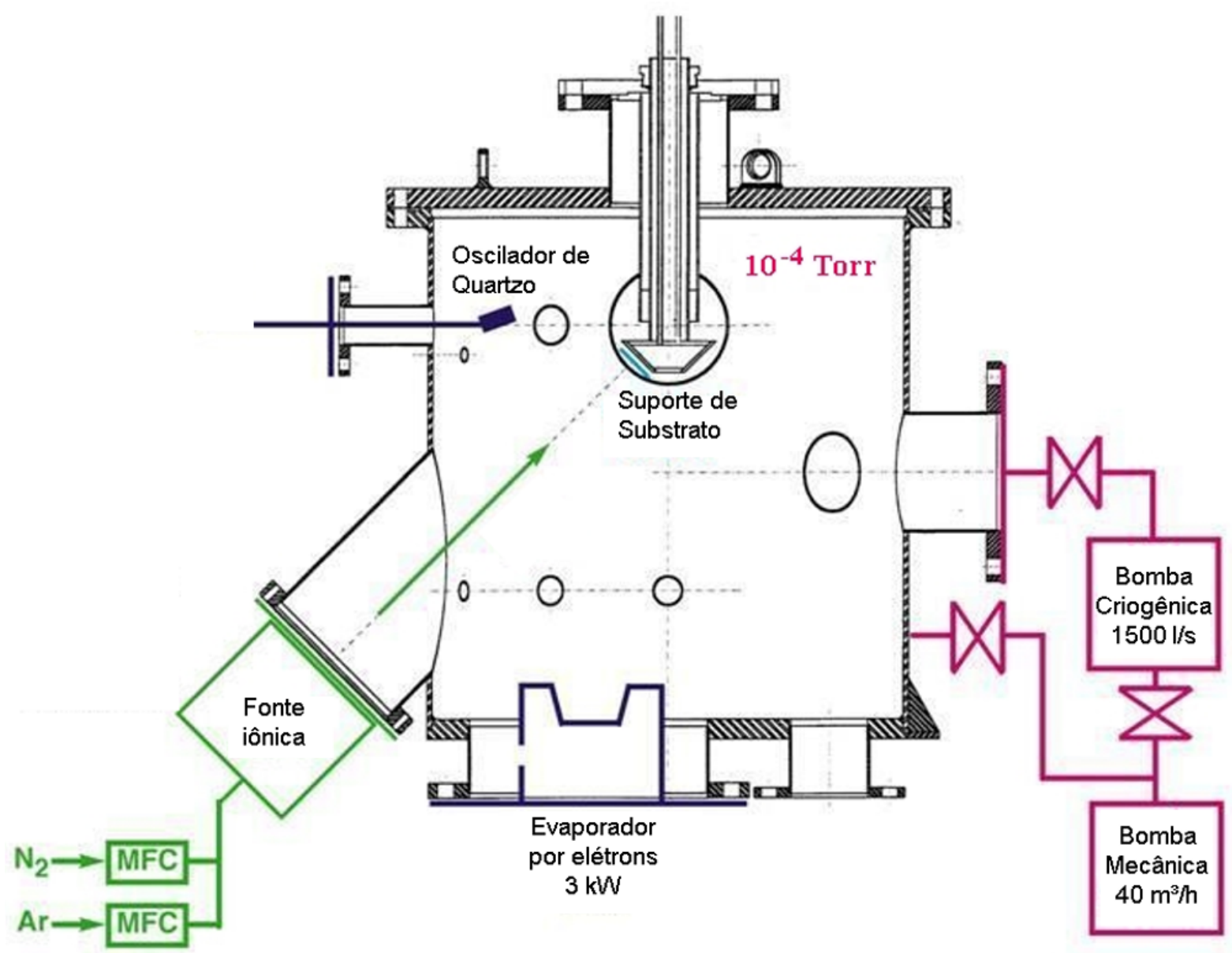

Figura 14 - Ilustração do sistema IBAD do LACIFID.

O arranjo está ilustrado na figura 14. Os dois suportes de substrato ficam no 
topo do cilindro. Eles estão fixados em extremidades opostas de uma barra giratória de modo que, enquanto um deles fica posicionado adequadamente para a deposição (posição principal), o outro está distante da região de deposição (posição secundária). A barra pode ser girada para inverter suas posições. Dois obturadores protegem os suportes para que não ocorra deposição enquanto os parâmetros de produção são ajustados. O obturador que protege a posição principal é móvel, permitindo que o experimentador exponha o substrato assim que os parâmetros de produção forem acertados.

A evaporadora por feixe de elétrons fica na base da câmara e forma ângulo de $45^{\circ}$ com o suporte em posição principal. A fonte iônica kaufman está presa na lateral do cilindro e forma ângulo de $90^{\circ}$ com este mesmo suporte. Este arranjo faz com que os íons acelerados e os átomos evaporados se encontrem somente na superfície do substrato, sendo improváveis colisões íon-átomo anteriores à deposição.

Fontes iônicas kaufman são um tipo de duoplasmatron. Elas consistem em uma câmara de vácuo, geralmente de formato cilíndrico, cujas paredes funcionam como anodo. Dentro delas há um filamento metálico, tipicamente de tungstênio. Este filamento libera elétrons ao ser aquecido (efeito termiônico). Um gás inserido em pequenas quantidades neste ambiente é ionizado ao se aplicar uma diferença de potencial entre catodo e anodo. Os íons são, então, acelerados por grades carregadas. É importante notar que esse sistema de ionização é inadequado para utilização de gases reativos, principalmente oxigênio, pois a corrosão e oxidação das paredes e do filamento podem destruir a capacidade de ionização e inutilizar o equipamento.

O oscilador de quartzo está posicionado na mesma altura do suporte principal. Isto permite que, durante o processo de formação dos filmes, a quantidade de átomos depositados no substrato seja semelhante à quantidade de átomos depositados no oscilador. Este último, entretanto, praticamente não recebe íons, pois não está na direção da aceleração iônica, diferentemente do substrato em posição principal. Logo, o oscilador serve para estimar exclusivamente a quantidade de átomos depositados, não a de íons.

O copo de faraday fica preso ao obturador principal. Portanto, fica dentro do ângulo sólido de incidência iônica e recebe pequena parcela dos átomos evaporados. Esse copo está conectado a um multímetro exterior à câmara, permitindo a estimativa do fluxo de íons que incide no substrato. Corrente típicas variam de décimos a unidades de miliamperes.

A pressão de fundo é da ordem de $10^{-5} \mathrm{~Pa}\left(10^{-7}\right.$ Torr $)$ e a pressão de trabalho varia entre $2 \cdot 10^{-2} \mathrm{~Pa}\left(2 \cdot 10^{-4}\right.$ Torr $)$ e $10^{-3} \mathrm{~Pa}\left(10^{-5}\right.$ Torr $)$, dependendo da taxa de evaporação e do fluxo iônico.

Os filmes aqui estudados foram produzidos através da evaporação de pastilhas de óxido de alumínio. Essas pastilhas foram sinterizadas a partir de pó de alumina alfa. O pó foi prensado isostaticamente e em seguida levado ao forno à temperatura de $1000{ }^{\circ} \mathrm{C}$ 
durante 2 horas. A deposição foi assistida com íons $\mathrm{Ar}^{+}$produzidos através da ionização de gás argônio com pureza de 99,999\%.

Para que seja possível compreender a relação entre as propriedades dos filmes e os parâmetros de produção deve-se comparar amostras cujas produções diferem em apenas um único parâmetro. Tendo isto em vista, neste trabalho foram produzidas 7 amostras sob as condições presentes na tabela 1. O parâmetro de produção que diferencia os filmes A, B, C, D e E é a energia do feixe; as amostras B e B2 diferem na razão de chegada; E e E2 diferem na temperatura. Os filmes foram depositados até que o monitorador de espessura indicasse $60 \mathrm{~nm}$.

Tabela 1 - Parâmetros do sistema IBAD utilizados na produção dos filmes de alumina

\begin{tabular}{cccc}
\hline Amostra & Energia $(\mathrm{eV})$ & $\mathrm{ARR}\left(\right.$ íon $\left./ \mathrm{Al}_{2} \mathrm{O}_{3}\right)$ & Temperatura $\left({ }^{\circ} \mathrm{C}\right)$ \\
\hline A & 0 & 0,0 & 30 \\
B & 150 & 1,2 & 30 \\
B2 & 150 & 0,7 & 30 \\
C & 300 & 1,2 & 30 \\
D & 600 & 1,2 & 30 \\
E & 900 & 1,2 & 30 \\
E2 & 900 & 1,2 & 450 \\
\hline
\end{tabular}

\subsection{Microscopia de força atômica}

As imagens de AFM foram adquiridas através de um SPM modelo SPM-9600 produzido pela Shimadzu Corporation e localizado no departamento de física do Centro Universitário da Fundação Educacional Inaciana Padre Sabóia de Medeiros. Foram tomadas imagens com dimensões de $(1,0 \times 1,0 \mu \mathrm{m}),(2,5 \times 2,5 \mu \mathrm{m})$ e $(5,0 \times 5,0 \mu \mathrm{m})$ e resolução de $256 \times 256$ pixels. A maioria das imagens foi adquirida por modo de contato intermitente. Somente a amostra A teve algumas imagens tomadas por modo de contato. As pontas utilizadas no modo de contato intermitente têm constante elástica entre $20 \mathrm{~N} / \mathrm{m}$ e 100 $\mathrm{N} / \mathrm{m}$ e são de $\mathrm{Si}$. No modo contato foram utilizadas pontas constituídas de $\mathrm{Si}_{3} \mathrm{~N}_{4}$ e com constante elástica entre $0,01 \mathrm{~N} / \mathrm{m}$ e 1,00 N/m. Todas as imagens assim adquiridas passaram por um tratamento digital básico denominado flatten. Este tratamento serve para "achatar" o fundo da imagem, eliminando sombras ou outros tipos de estruturas não realistas. Esse processamento ajusta um polinômio de grau 3 ou menor em alguma linha da imagem e subtrai este polinômio de todas as linhas (CHINAGLIA, 2002).

\subsection{Difração de raios-x}

As medidas de XRD foram realizadas no Laboratório de Cristalografia do IFUSP utilizando o difratômetro da Bruker Corporation modelo D8 Discover. Este equipamento 
possui tubo de cobre (radiação K- $\alpha$ de 1,5418 $\AA$ ) para produção de raios-x e detector modelo LYNXEYE. O LYNXEYE é um detector de estado sólido composto de silício, com 192 tiras independentes e área útil de 14,4 mm por 16,0 mm. O tubo e o detector são controlados por motores independente com resolução angular de 0,0001 . A medida foi realizada com arranjo Bragg-Brentano $\theta-\theta$ : a amostra fica fixada; o detector se move com velocidade angular $\omega$ e o tubo se move com velocidade angular $-\omega$. A fenda de divergência e a fenda de chegada ao detector possuem $0,5 \mathrm{~mm}$ e $5 \mathrm{~mm}$, respectivamente. A óptica do equipamento conta também conta duas fendas soller para controlar a divergência do feixe incidente e do feixe difratado. Os raios- $\mathrm{x}$ foram gerados aplicando $40 \mathrm{kV}$ e corrente de 30 $\mathrm{mA}$ no tubo. Um filtro de níquel foi posicionado na frente do detector para amenizar a intensidade relativa das linhas K- $\beta$. O intervalo de medida foi de $10^{\circ}$ até $120^{\circ}$ com passos de $0,05^{\circ}$. O tempo de aquisição foi de $1 \mathrm{~s}$ por ponto. As amostras foram giradas com frequência de $30 \mathrm{rpm}$ durante as medidas.

\subsection{Refletividade de raios-x}

O experimento de XRR também foi realizado no laboratório de cristalografia do IFUSP. O equipamento utilizado nas medidas foi o Ultima-Plus da Rigaku. Ele utiliza um tubo de cobre como fontes de raios-x. A intensidade do feixe refletido foi medida por um detector a cintilação com janela de aproximadamente 2,5 cm. Diferentemente do equipamento utilizado na XRD, o Ultima-Plus possui um monocromador de LiF pósamostra. Por esta razão, além das fendas de divergência e de chegada, o sistema conta com duas fendas pré-monocromador. Os dados de XRR também foram tomados através do arranjo Bragg-Brentano $\theta-\theta$. O intervalo de medida em $2 \theta$ foi de $0,30^{\circ}$ até $4,00^{\circ}$ com passos de $0,02^{\circ}$, sendo que a resolução do equipamento é $0,01^{\circ}$. O detector a cintilação não pode receber mais do que cem mil contagens por segundo; portanto, nas medidas de ângulo baixo, quando a reflexão é alta, a intensidade de raios-x incidente deve ser baixa. Contudo, como a curva de refletividade é decrescente, para manter um bom sinal de detecção é necessário aumentar a intensidade do feixe e o tempo de medida conforme o ângulo aumenta. Por isso, o intervalo de $0,30^{\circ}$ a $4,00^{\circ}$ foi divido em três partes, cada uma com diferentes intensidades de feixe e tempo de detecção. A tabela 2 contém a corrente, a tensão e o tempo utilizados nos três intervalos.

Tabela 2 - Parâmetros experimentais das medidas de XRR

\begin{tabular}{cccc}
\hline Intervalo & Corrente $(\mathrm{mA})$ & Tensão $(\mathrm{kV})$ & Tempo $(\mathrm{s})$ \\
\hline $1^{\mathrm{o}}$ & 4 & 20 & 5 \\
$2^{\mathrm{o}}$ & 10 & 40 & 15 \\
$3^{\mathrm{o}}$ & 30 & 40 & 30 \\
\hline
\end{tabular}




\subsection{Análise por feixes iônicos}

As análises por feixes iônicos foram realizadas no Laboratório de Análise de Materiais por Feixes Iônicos (LAMFI) do IFUSP. O LAMFI possui um acelerador eletrostático Van der Graaff Tandem com tensão nominal de 1,7 MV. Este acelerador possui duas fontes iônicas: uma Alphatross, para gerar as partículas alpha, e outra SNICS, para gerar feixe de oxigênio. O sistema é evacuado através de bombas mecânicas e turbo-moleculares (MORO, 2013).

Os experimentos RBS/EBS/ERDA são definidos por quatro parâmetros fundamentais: o tipo de feixe iônico, a energia do feixe iônico, a posição angular do detector $(\theta)$ e a inclinação da amostra relativamente à direção de incidência do feixe $(\varphi)$. Neste trabalharam foram realizadas várias medidas com diferentes combinações desses parâmetros. A tabela 3 descreve todas as medidas relativamente a esses quatro parâmetros. As vantagens e desvantagens de cada um dos arranjos serão discutidas na seção de análise e resultados.

Tabela 3 - Arranjos experimentais das análises por feixes iônico

\begin{tabular}{cccccc}
\hline Arranjo & Técnica & Feixe & Energia $(\mathrm{MeV})$ & $\theta\left(^{\circ}\right)$ & $\varphi\left(^{\circ}\right)$ \\
\hline 1 & RBS/EBS & $\alpha$ & 3,038 & 170 & 10 \\
2 & RBS/EBS & $\alpha$ & 3,038 & 120 & 7 \\
3 & RBS/EBS & $\alpha$ & 3,038 & 170 & 7 \\
4 & RBS/EBS & $\alpha$ & 3,038 & 170 & 10 \\
5 & ERDA & $\alpha$ & 3,038 & 20 & 80 \\
6 & ERDA & $\mathrm{O}$ & 5,002 & 45 & 60 \\
\hline
\end{tabular}

O arranjo 5 tem o propósito de quantificar a concentração de H nos filmes. Portanto, neste arranjo foi colocada uma folha de alumínio com espessura equivalente a $1,3 \cdot 10^{5}$ TFU de silício na frente da janela do detector. Esta folha impede a detecção de qualquer elemento químico que não seja o $\mathrm{H}$. 



\section{Análise e resultados}

\subsection{Difração de raios-x}

Os dados de XRD foram analisados a partir da comparação entre os difratogramas das amostras e o difratograma do substrato ${ }^{1}$. A figura 15 contém os dados da amostra E (produzida com 900 eV e temperatura ambiente) e do substrato de Si (100) puro. Ao observá-la fica claro que todos os picos presentes na amostra de alumina entre $10^{\circ}$ e $120^{\circ}$ também estão presentes no Si. Se todos os picos do difratograma da amostra também aparecem no difratograma do substrato, só se pode inferir que a amostra é totalmente amorfa, não possui nenhuma estrutura cristalina; ou possui cristalitos subnanométricos, menores do que a resolução de detecção (CULLITY; STOCK, 2001a).
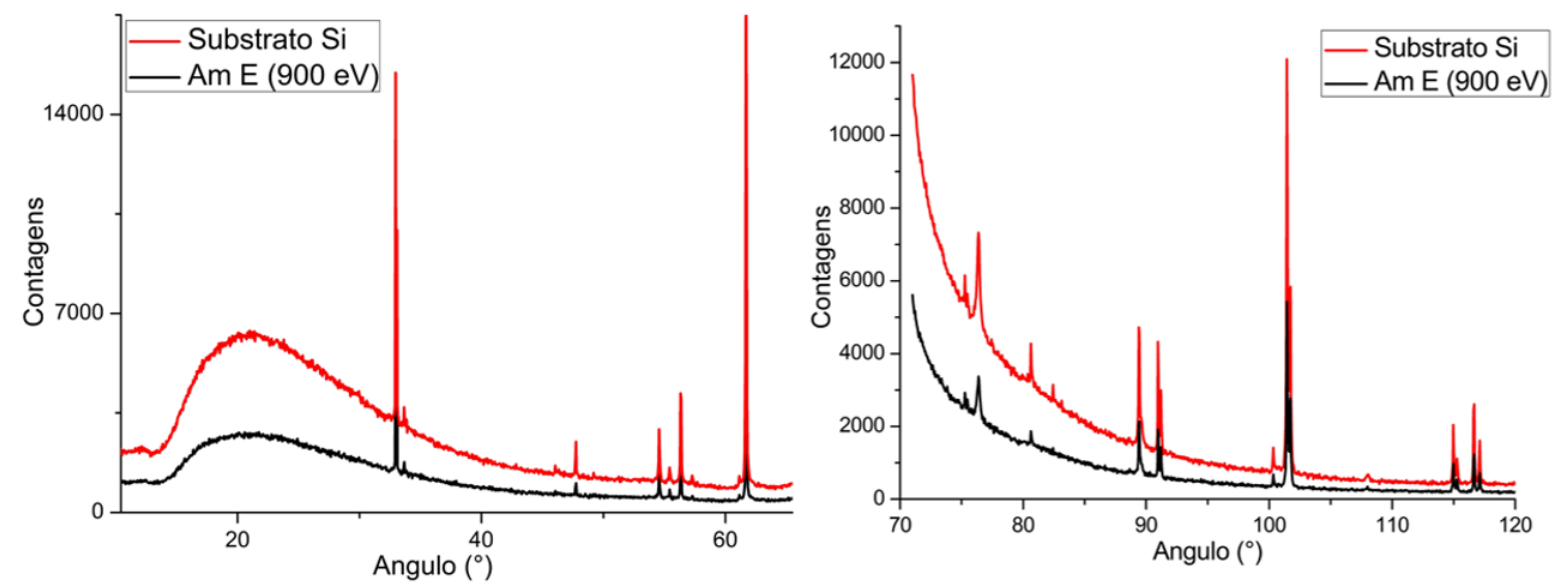

Figura 15 - Difratogramas da amostra E $(900 \mathrm{eV})$ e do substrato de Si. Não foi medida a região entre $67^{\circ}$ e $71^{\circ}$ para evitar o intenso pico do plano (400) do Si.

Na figura 16, o difratograma da amostra E foi comparado com os das amostras produzidas com diferentes energias para estabelecer se o feixe iônico influiu na cristalização. A comparação expõe que todos os filmes, incluindo aquele produzido sem assistência do feixe iônico, apresentam os mesmos picos. Portanto, as conclusões a respeito da estrutura da amostra E valem para as amostras A, B, C e D.

Os difratogramas dos filmes E e E2 - que foram produzidos com os mesmos parâmetros, salvo pela temperatura - estão plotados na figura 16. Novamente, não existe nenhuma diferença visível que permita inferir que E2 possui estrutura cristalina distinta

1 As comparações aqui realizadas foram viáveis, pois todos os difratogramas foram obtidos nas mesmas condições (equipamentos e parâmetros iguais). A variação de parâmetros experimentais, tais como a rotação da amostra e a utilização de monocromadores, pode alterar os difratogramas. 

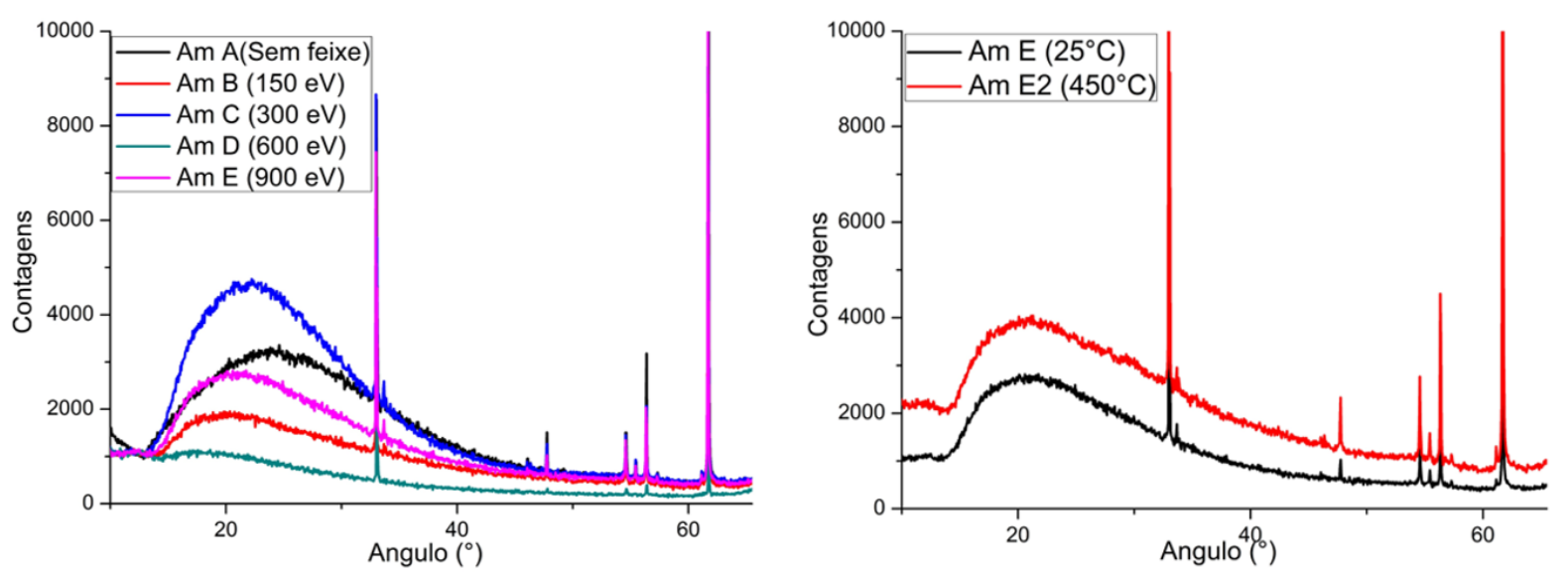

Figura 16 - Difratograma de filmes produzidos com diferentes energias (esquerda) e de amostras produzidas à diferentes temperaturas (direita).

de E. Portanto, a temperatura de deposição de $450{ }^{\circ} \mathrm{C}$ e o bombardeamento de íons $\mathrm{Ar}^{+}$ com 900 eV não foram suficientes para formar cristalitos mensuráveis.

\subsection{Microscopia de força atômica}

Em oposição aos dados de XRD, a técnica AFM evidenciou que o feixe de íons pode causar variações nas propriedades dos filmes de alumina. As imagens de AFM (figura 17) da amostra A (produzida sem feixe iônico) apresentam um padrão de alternância entre linhas subparalelas claras e escuras. Tal padrão é evidente nas imagens com lado de 2,5 $\mu \mathrm{m}$ e $5,0 \mu \mathrm{m}$.
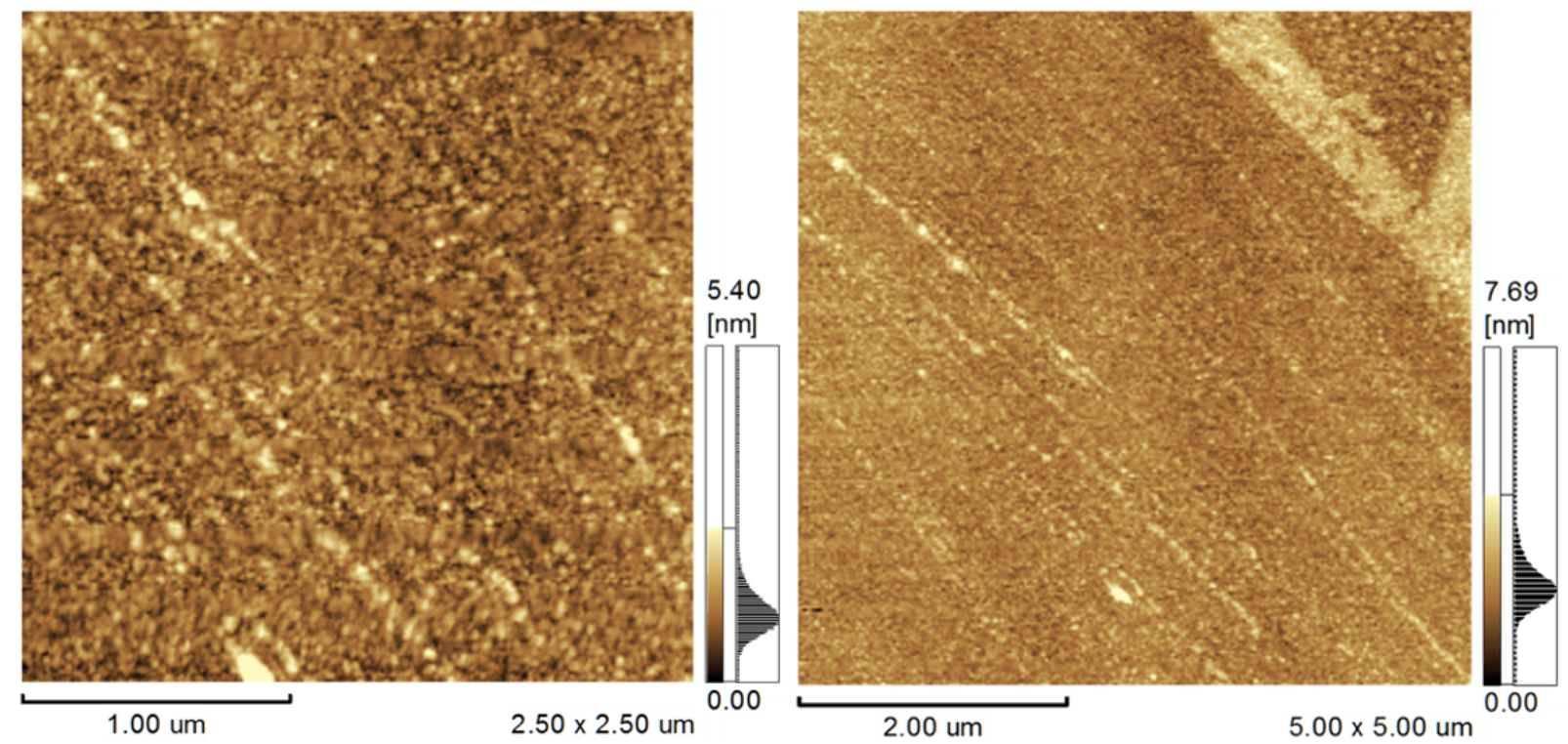

Figura 17 - Imagens da amostra A (sem feixe iônico) obtidas através de modo contato. As nítidas linhas subparalelas indicam que a superfície da amostra não é uniforme. 
O padrão topográfico de A não se repetiu em nenhuma outra amostra, o que permite concluir que o bombardeamento iônico destrói o padrão de crescimento preferencial visto em A. As amostras B, C, D e E possuem superfícies bastante lisas (figura 18). A baixíssima rugosidade das amostras exige que sonda de varredura do microscópio realize movimentos verticais muito próximos do limite de resolução do equipamento. Isto contribui para os ruídos visíveis em algumas das imagens.

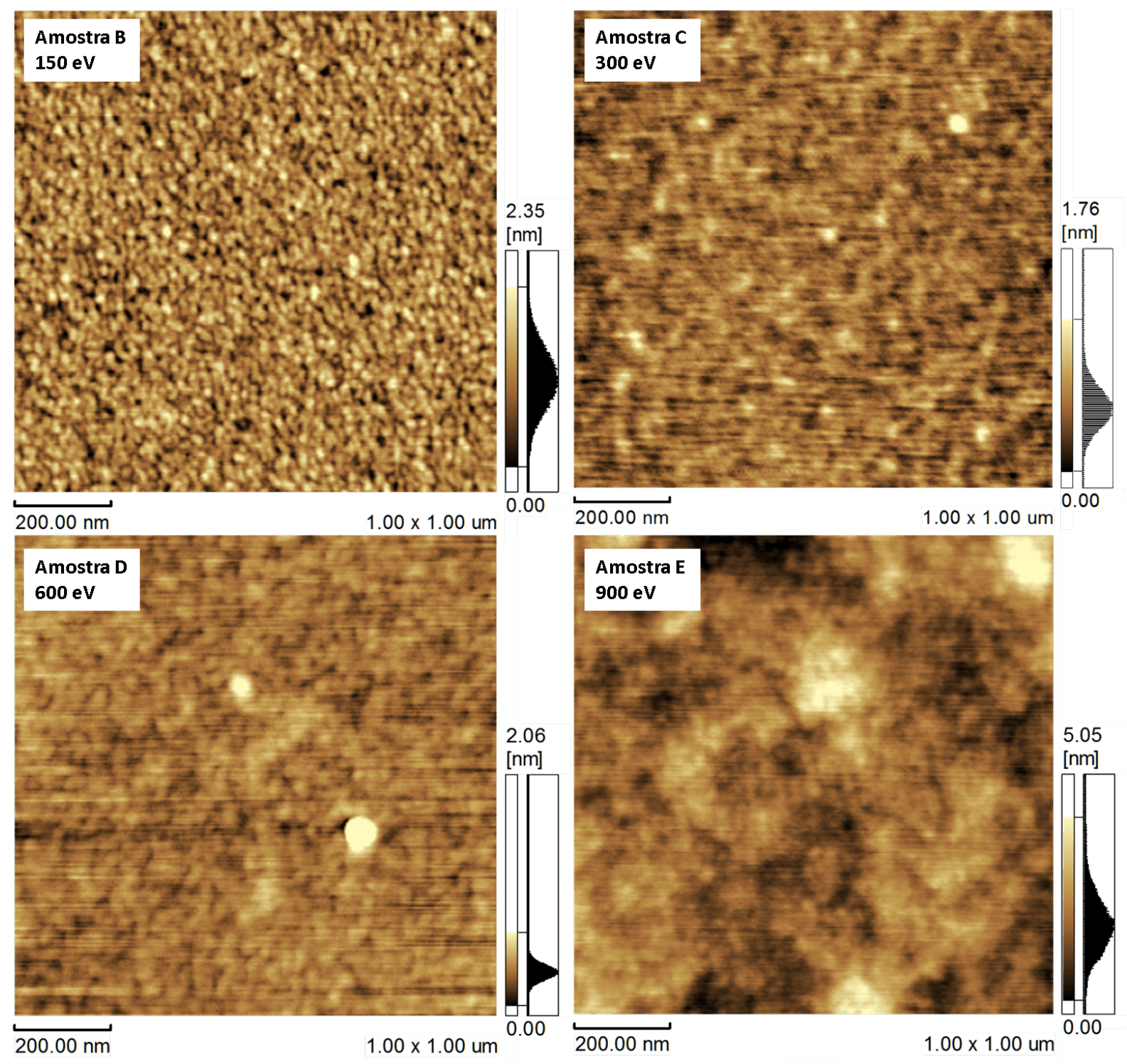

Figura 18 - Imagens obtidas por modo de contato intermitente de amostras produzidas com diferentes energias.

Todos os filmes tiveram sua rugosidade $R_{r m s}$ quantificada. A rugosidade $R_{r m s}$ é definida como o desvio quadrático médio da altura dos $N$ pontos superficiais varridos (CHINAGLIA, 2002), isto é,

$$
R_{r m s}=\sqrt{\sum_{i=0}^{N} \frac{y_{i}^{2}}{N}},
$$


onde $y_{i}$ é a altura do ponto $i$ em relação à altura média dos $N$ pontos varridos. Os valores de $R_{r m s}$ de todos os filmes estão compilados na tabela 4.

Tabela 4 - Rugosidades obtidas por AFM

\begin{tabular}{cc}
\hline Amostra & $R_{r m s}(\mathrm{~nm})$ \\
\hline A & $0,795(42)$ \\
B & $0,408(6)$ \\
B2 & $0,616(39)$ \\
C & $0,246(24)$ \\
D & $0,214(8)$ \\
E & $0,852(49)$ \\
E2 & $0,641(28)$ \\
\hline
\end{tabular}

Os dados morfológicos das amostras B e B2 são evidência de que a razão de chegada influencia na rugosidade. B2 possui ARR menor e $R_{r m s}$ maior do que B. A diferença de rugosidade é significativa relativamente à incerteza experimental. Também foram encontradas diferenças significativas entre os valores de $R_{r m s}$ das amostras E e E2. E2, produzida a $450{ }^{\circ} \mathrm{C}$, possui superfície mais lisa.

A figura 19 apresenta o valor de $R_{r m s}$ em função da energia (amostras A, B, C, D e E). Ela indica que a rugosidade pode ser controlada a partir da energia do feixe iônico. Filmes produzidos na região entre $300 \mathrm{eV}$ e $600 \mathrm{eV}$ possuem menor $R_{r m s}$. Nos extremos do intervalo de 0 a $900 \mathrm{eV}$, os filmes são mais rugosos.

A técnica de AFM mostrou também a influência do bombardeamento de argônio e da temperatura sobre a morfologia dos filmes de alumina. O aumento da energia de $150 \mathrm{eV}$ (amostra B) para $900 \mathrm{eV}$ (amostra E) causou um aumento dos grãos presentes na superfície dos filmes. O mesmo pode se dizer para aumento de temperatura e para a diminuição do ARR. Estes fatos podem ser constatados na figura 20.

\subsection{Refletividade de raios- $x$}

Como descrito anteriormente, as curvas de refletividade em função do ângulo de reflexão são decrescentes. Isto significa que, em um experimento de XRR, o sinal detectado em grandes ângulos é baixo. Em contrapartida, em ângulos baixos, onde a intensidade refletida é alta, o sinal detectado é tão forte que, se não controlado adequadamente, pode até mesmo danificar o detector. A solução para conciliar estas duas características do experimento de XRR é iniciar a medida utilizando um feixe de baixa intensidade e aumentá-la toda vez que o sinal detectado se tornar inadequadamente baixo. Isto faz com que os dados brutos de refletividade tenham a aparência da figura 21. As descontinuidades vistas nesta imagem são resultado do aumento de intensidade do feixe que se aplica para aumentar o sinal detectado. 


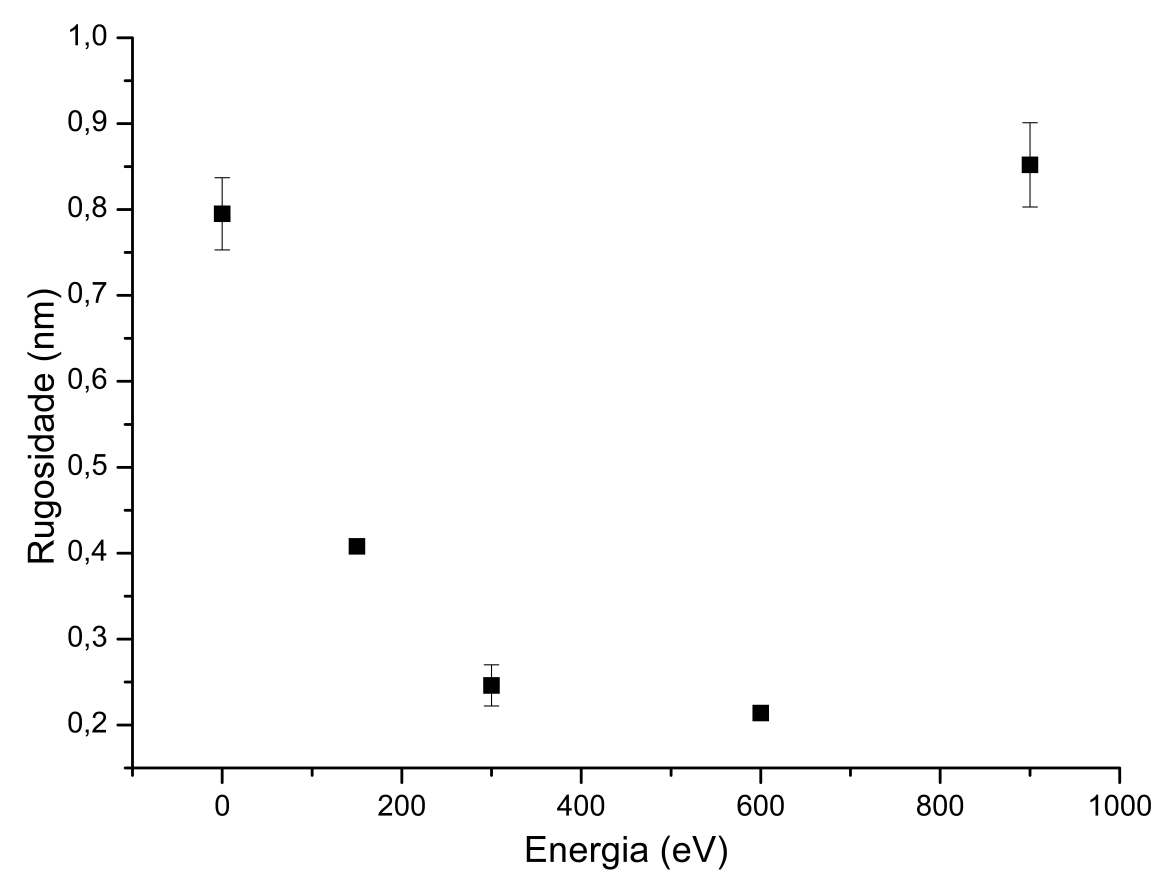

Figura 19 - Rugosidade versus energia de produção. Os pontos no gráfico representam as $\operatorname{amostras} \mathrm{A}, \mathrm{B}, \mathrm{C}, \mathrm{D}$ e E.

O início da análise de dados de XRR se dá tratando os dados brutos de refletividade de modo a transformá-los em uma curva contínua: para todos os pontos de descontinuidade calculou-se o fator (menor que a unidade) que, ao multiplicar o segmento a direita da descontinuidade, conecta os trechos descontínuos. Além disso, as curvas foram normalizadas, deixando o ponto máximo da refletividade com valor de unidade. Na figura 22 estão sobrepostos os dados tratados da amostra C (300 eV) e uma simulação de um filme de alumina sobre silício feita através software GenX² (BJÖRCK; ANDERSSON, 2007). A simulação foi construída supondo que a alumina possui densidade regular $\left(3,97 \mathrm{~g} / \mathrm{cm}^{3}\right)$ (OTT et al., 1996), nenhuma rugosidade e $60 \mathrm{~nm}$ de espessura (valor nominal utilizado na produção dos filmes). Comparando a simulação com os dados da amostra C, nota-se diferenças no ângulo crítico, na amplitude e na distância entre as franjas do padrão de interferência. A diferença dos ângulos críticos e das amplitudes indicam que a densidade do filme de alumina é muito menor do que $3,97 \mathrm{~g} / \mathrm{cm}^{3}$. O fato de a curva de refletividade do filme $\mathrm{C}$ possuir menor distância entre as franjas mostra que a espessura do filme é maior do que $60 \mathrm{~nm}$. Todas as amostras exibiram as mesmas características relativamente a essa simulação.

A figura 23 contém o começo da curva de refletividade de várias amostras. É notório

$\overline{2}$ O GenX é um programa de computador gratuito que utiliza os modelos teóricos descritos em 2.5 para simular e ajustar curvas de refletividade. Todas as simulações e ajustes de refletividade deste trabalho foram feitas através dele. 

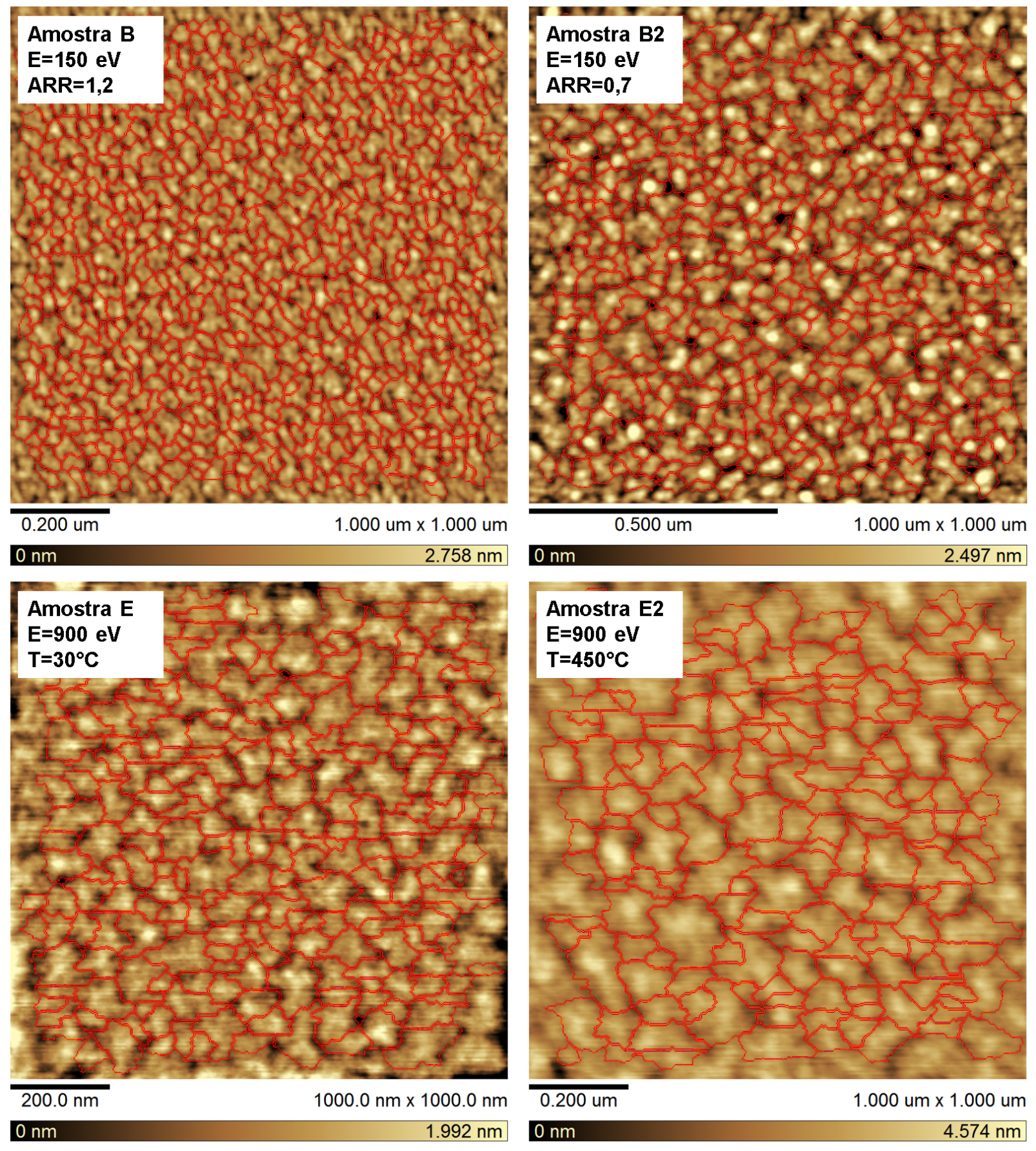

Figura 20 - Comparação entre os tamanhos dos grãos. O aumento da ARR diminuiu os grãos (amostras B e B2). O aumento da temperatura de produção os aumentou (amostras E e E2.) 


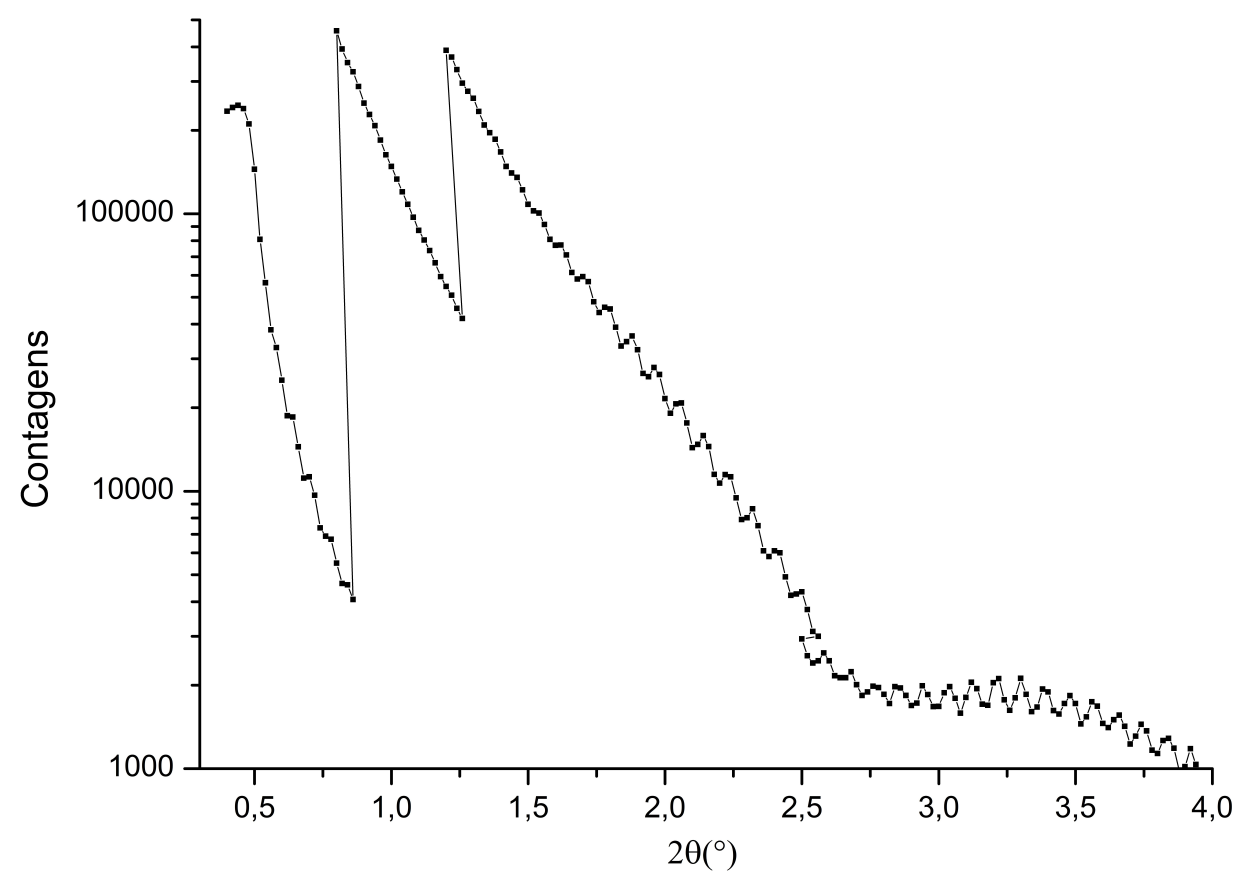

Figura 21 - Dados brutos de refletividade da amostra B. As descontinuidades da curva são resultado do aumento de intensidade dos raios-x e do aumento do tempo de aquisição. O aumento destes dois parâmetros experimentais serve para aumentar o sinal detectado.

que o ângulo crítico da amostra A é menor do que os outros. Todas as outras amostras têm ângulos críticos compatíveis entre si. Isto significa que o feixe iônico contribuiu para a densificação dos filmes, porém a densificação não varia perceptivelmente com a energia do feixe. Os filmes E e E2, produzidos com temperaturas distintas, apresentam mesmo ângulo crítico. Utilizando a equação (2.12) para calcular a densidade diretamente através do ângulo crítico, obtém-se que a amostra produzida sem feixe possui densidade de 2,45 $\mathrm{g} / \mathrm{cm}^{3}$ e as amostras produzidas com assistência de feixe de $\mathrm{Ar}^{+}$têm densidade de 2,79 $\mathrm{g} / \mathrm{cm}^{3}$.

O software GenX também foi utilizado para ajustar curvas de refletividade aos dados experimentais de todas as amostras. Para fazer, o ajuste o software utiliza o conceito de scattering length density (SLD). A definição matemática de SLD para raios-x é:

$$
S L D=\frac{\sum_{i=1}^{n} r_{e} Z}{V},
$$

onde $Z$ é o número atômico do $i$-ésimo átomo contido no volume $V$ e $r_{e}$ é o raio clássico do elétron. A SLD para raios-x é uma grandeza muito próxima da densidade eletrônica. Porém, devido ao fator $r_{e}$, ela possui unidade de área ${ }^{-1}$, não de volume ${ }^{-1}$.

Para fazer o ajuste, é necessário fornecer ao GenX a composição atômica e os parâmetros básicos (rugosidade, espessura e densidade) do(s) filme(s), além da composição 


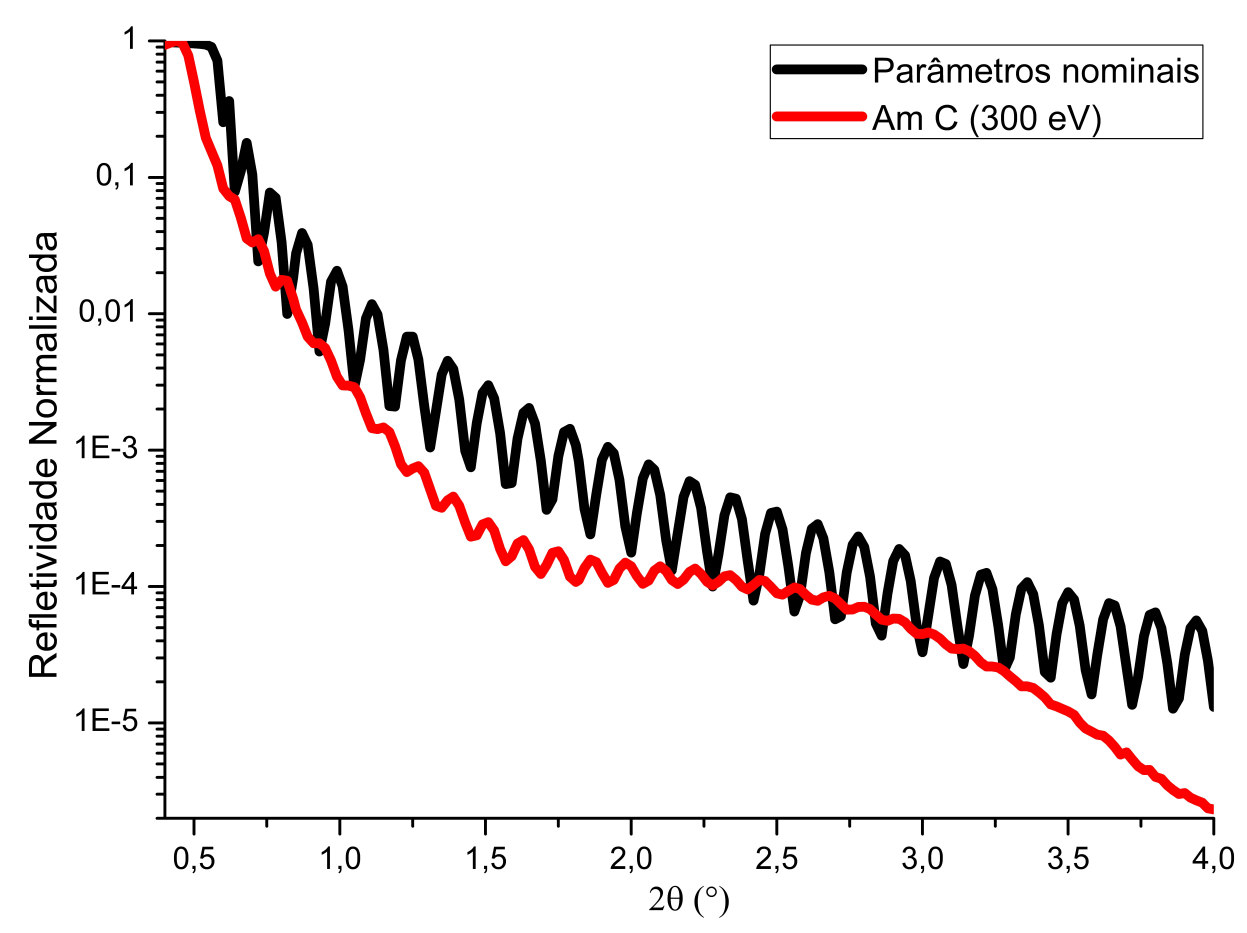

Figura 22 - Comparação entre os dados de refletividade da amostra C e uma simulação feita com os parâmetros nominais dos filmes.

e densidade do substrato. O software varia todos parâmetros até encontrar a SLD em função da profundidade que melhor descreve os dados experimentais. O único parâmetro que o software não ajusta é a composição. Isso não interfere em nada o ajuste, pois a refletividade depende somente da densidade eletrônica (ou da SLD) em função da profundidade. Contudo, fornecer a composição correta ao software permite que ele associe corretamente a densidade (eletrônica, atômica ou de massa) e a SLD.

Os métodos de ajuste geralmente funcionam através de uma função (ou figura de mérito) que indica o quão próximo o ajuste está dos dados experimentais (PRESS et al., 1992a). No método dos mínimos quadrados, por exemplo, essa função é a somatória do quadrado dos resíduos reduzidos (função $Q^{2}$ ). O $Q^{2}$ é particularmente eficiente se as incertezas forem estimadas estatisticamente (incertezas do tipo A). Contudo, no método de XRR há predominância de incertezas não estatísticas (tipo B). As fontes dessas incertezas são pequenos erros de alinhamento do detector, da superfície da amostra e, principalmente, os fatores que são aplicados aos dados brutos para transformá-los em uma curva continua. Por esta razão foi escolhida uma figura de mérito $F M$ que não leva em consideração as incertezas:

$$
F M=\frac{\sum_{i=1}^{N}\left(\log _{10} Y_{i}-\log _{10} Y_{a}\right)}{N-p},
$$

onde $N$ é o número de pontos experimentais, $p$ é o número de parâmetros ajustados, $Y_{i}$ é 


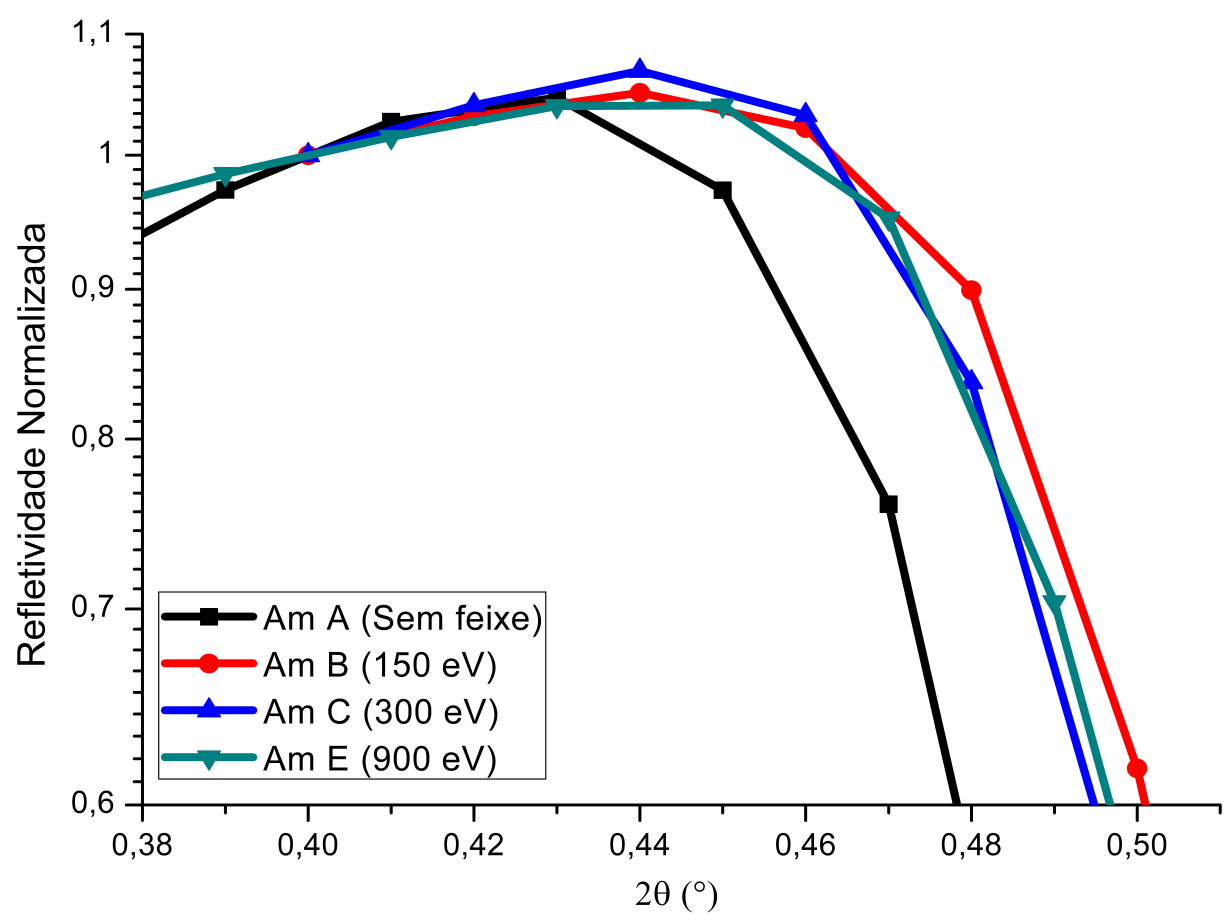

Figura 23 - Começo da curva de refletividade de várias amostras. Observa-se que O filme produzido sem assistência de feixe iônico possui ângulo crítico (e, portanto, densidade) menor que os demais.

a ordenada do $i$-ésimo ponto e $Y_{a}$ é ordenada do ajuste na coordenada do $i$-ésimo ponto.

O GenX possui diversos métodos de optimização da $F M$. Aqui utilizou-se o método simplex (PRESS et al., 1992b). Os ajustes foram feitos variando os parâmetros do filme, a rugosidade do substrato e o offset dos dados. Ao offset permitiu-se uma variação muito pequena - apenas 1 décimo da precisão instrumental - de modo a refinar o ajuste sem comprometer sua verossimilhança. É importante ressaltar que a relação entre refletividade e SLD não é unívoca. SLDs distintas podem levar à mesma curva de refletividade. Portanto, ao fazer o ajuste dos dados é necessário restringir os intervalos de variação dos parâmetros para que os resultados não sejam meras soluções matemáticas, mas encontrem respaldo na realidade das amostras. Exemplificando, a figura 24 contém dois ajustes da amostra B com FM similar. Apesar da FM semelhante, a SLD destes dois ajustes é bastante diferente.

Todos os filmes de alumina apresentaram gráficos de SLD semelhantes. Eles possuem SLD predominantemente uniforme, com variações pequenas ao longo da profundidade, porém com um pico próximo à superfície (profundidade menor que $5 \mathrm{~nm}$ ). Essa uniformidade sugere que os filmes não possuem grandes variações de composição em função da profundidade. O aumento de densidade eletrônica na região da superfície é um fenômeno já relatado em filmes finos de alumina produzidos por atomic layer deposition (HWANG et 


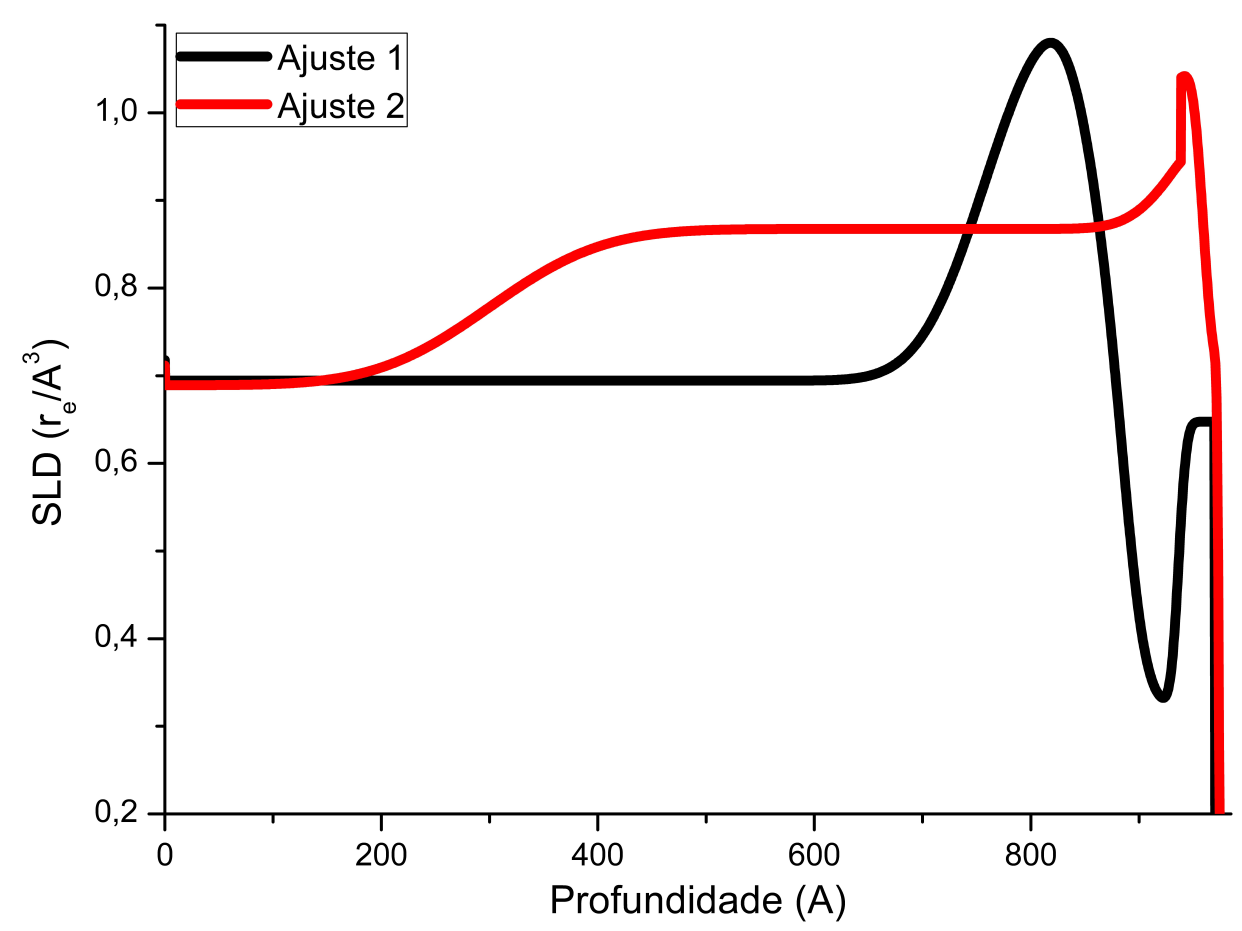

Figura 24 - SLDs obtidos através de dois distintos ajustes da amostra B. Apesar de os ajustes possuírem mesma qualidade estatística $(F M=0,02)$, o ajuste 2 obteve densidades verossímeis $\left(\approx 2,75 \mathrm{~g} / \mathrm{cm}^{3}\right)$ e o ajuste 1 não. Profundidades negativas representam o substrato.

al., 2006). Outro aspecto das curvas de SLD é transição suave que se observa na região da interface filme-substrato. Esta suavidade é um indicativo de que a interface filme-substrato não é bem definida, isto é, há uma camada intermediária entre filme e substrato. Todos os ajustes possuem $F M$ entre $2 \cdot 10^{-2}$ e $4 \cdot 10^{-2}$. O manual do GenX sugere que bons ajustes têm $F M$ menor do que $9 \cdot 10^{-2}$.

Tabela 5 - Densidade, espessura e rugosidade obtidas através do GenX

\begin{tabular}{cccc}
\hline Amostra & Densidade $\left(\mathrm{g} / \mathrm{cm}^{3}\right)$ & Espessura $(\AA)$ & Rugosidade $(\AA)$ \\
\hline A & 2,84 & 888 & 3,8 \\
B & 2,71 & 974 & 1,4 \\
B2 & 2,72 & 824 & 6,5 \\
C & 2,70 & 709 & 2,9 \\
D & 2,60 & 907 & 4,8 \\
E & 2,88 & 986 & 8,2 \\
E2 & 2,82 & 797 & 4,1 \\
\hline
\end{tabular}

As características das amostras obtidas através dos ajustes estão resumidas na tabela 5. Não há correlação aparente entre a densidade, as espessuras, as rugosidades e os parâmetros de produção. Contudo, é possível perceber características gerais dos filmes. De 


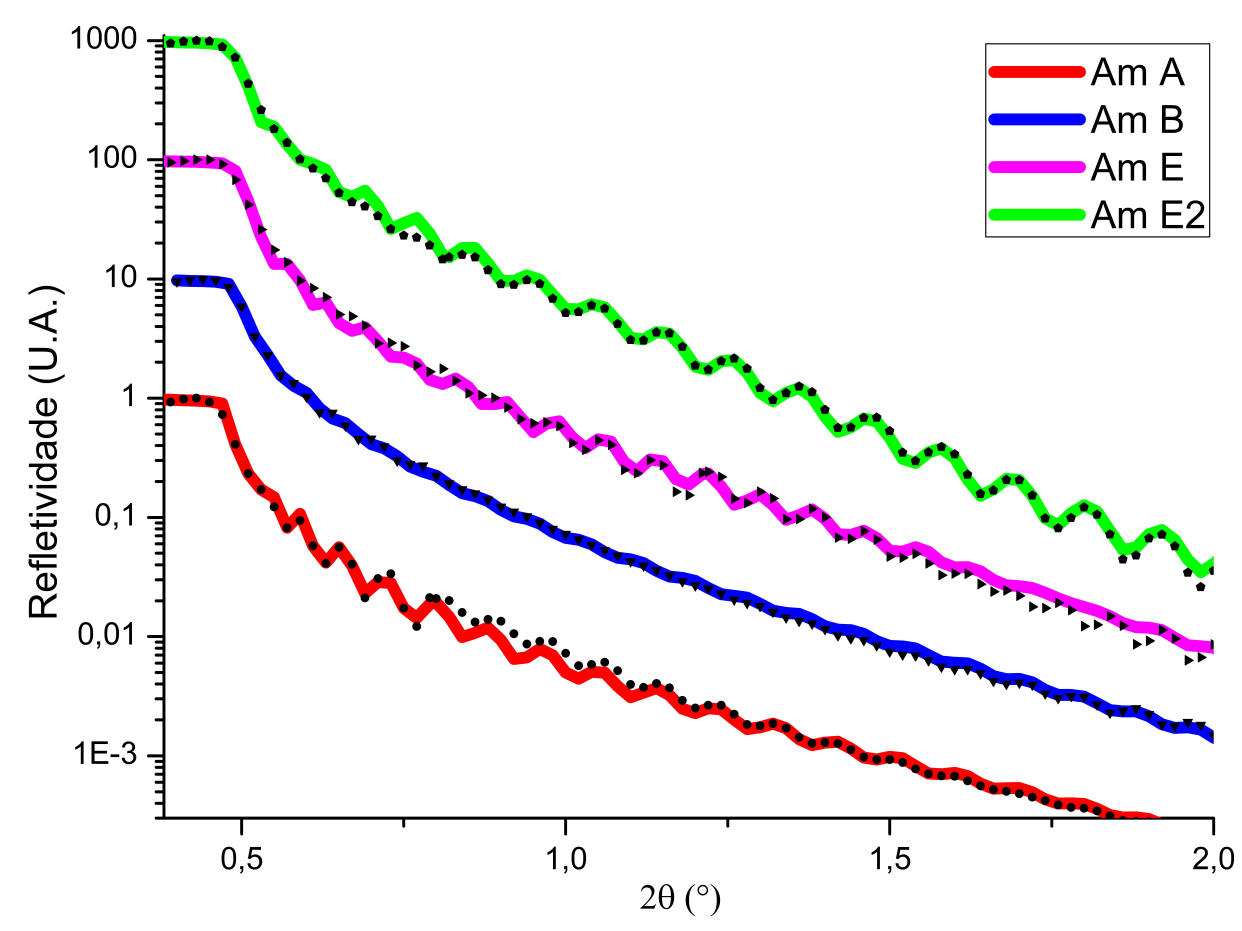

Figura 25 - Ajustes de refletividade de várias amostras. As curvas foram deslocados no eixo das ordenadas para facilitar a leitura do gráfico.

acordo com o que foi colocado a partir da figura 22, todos os filmes possuem espessura maior do que o valor nominal e densidade menor do que $3,97 \mathrm{~g} / \mathrm{cm}^{3}$. As espessuras variaram entre $70 \mathrm{~nm}$ e $100 \mathrm{~nm}$. As densidades se mantiveram ao redor de 2,75 g/ $\mathrm{cm}^{3}$. Nenhuma rugosidade é maior do que $1 \mathrm{~nm}$.

\subsection{Análise por feixes iônicos}

Um dos principais propósitos da assistência do feixe iônico na deposição de filmes finos é eliminar contaminantes leves. O hidrogênio, por exemplo, é um contaminante muito comum por estar presente na atmosfera. Medidas de ERDA com feixe de partículas alfa foram utilizadas para quantificar a presença de hidrogênio nos filmes de alumina. Os dados dessas medidas estão na figura 27. É notório que o filme com mais hidrogênio é aquele produzido sem assistência de feixe iônico (amostra A). O sinal detectado é particularmente pequeno para as amostras E e E2, comparativamente às demais. Em síntese, a figura 27 mostra que o aumento de energia, de ARR e de temperatura levaram à diminuição da concentração de hidrogênio.

A presença de Ar nas amostras pode ser observada nos espectros RBS/EBS obtidos através do arranjo 4 (tabela 3). Os picos destes espectros referentes ao Ar estão plotados 


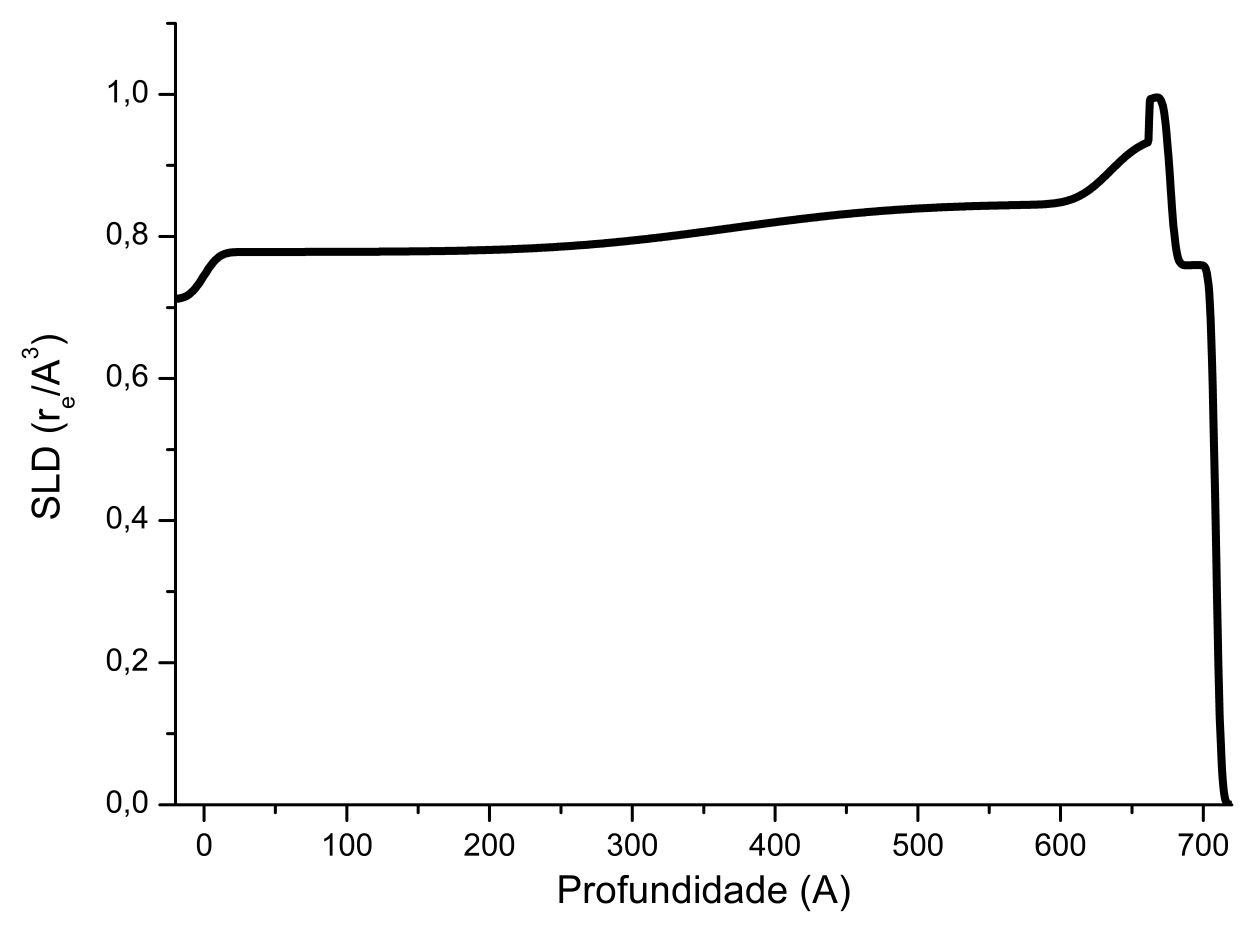

Figura 26 - SLD da amostra C. Todas as outras amostras apresentaram o mesmo padrão de SLD: uma região de alta densidade eletrônica próxima à superfície, variações pequenas em relação à profundidade e decaimento suave na região da interface filme-substrato.

na figura 28. Evidentemente, a amostra A praticamente não apresenta sinal proveniente do Ar. A concentração de Ar aumenta com a energia e com a ARR.

As concentrações de Ar e H podem ser analisadas qualitativamente a partir das figuras apresentadas. Contudo, é necessário quantificar esses e outros elementos para bem compreender o efeito do feixe iônico sobre as qualidades dos filmes de alumina. A composição e o perfil de profundidade da composição foram obtidos através dos softwares SIMNRA e MultiSIMNRA. O SIMNRA é um programa de computador que utiliza os princípios apresentados na seção 2.5 para simular e ajustar espectros de análise por feixe iônico (MAYER, 2011). Seu funcionamento é análogo ao GenX, isto é, o usuário insere os dados experimentais e informações básicas (composição e estequiometria) do material em análise. Então, o programa simula o espectro de acordo com as informações fornecidas. Por fim, ele varia os parâmetros do filme até encontrar os valores que melhor descrevem os dados. O SIMNRA utiliza em seus cálculos seções de choque Rutherford ou, quando o comportamento de um elemento não é Rutherford, ele usa o SigmaCalc - que é o modelo semi-empírico de Gurbich (GURBICH, 2016). O poder de freamento é calculado a partir do software SRIM, já citado anteriormente. O SIMNRA possui duas grandes limitações: (I) as amostras só podem ter uma única camada ajustada por vez - se o filme possuir 


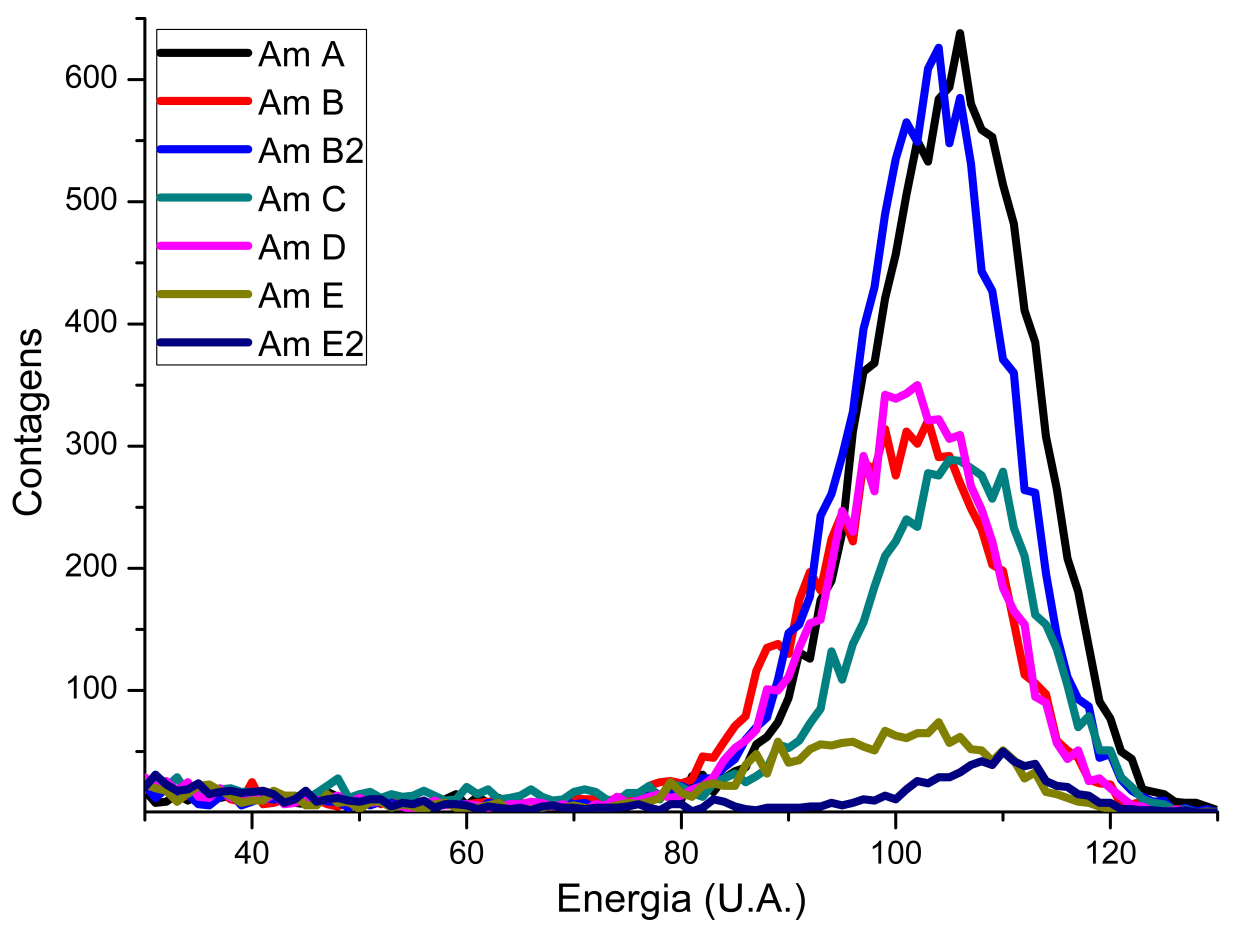

Figura 27 - Sinal referente à detecção de H obtido pela técnica de ERDA com feixe de partículas alfa. O aumento de energia resultou na diminuição da concentração de $\mathrm{H}$.

multicamadas ou gradientes de composição, ajustar o espectro camada por camada pode ser inviável - e (II) somente um único espectro pode ser ajustado por vez.

De acordo com o que foi descrito na seção 2.5, experimentos de análise por feixe iônico podem ser realizados de várias maneiras, sendo que cada uma delas possui vantagens e desvantagens. Alguns exemplos são: medidas de ERDA com partículas alfa quantificam bem a presença de $\mathrm{H}$, mas nenhum outro elemento; medidas de ERDA feitas com feixe pesado possuem boa resolução de profundidade, porém não quantificam tão bem quanto a RBS. RBS feita com alto ângulo de detecção fornece boa separação entre os elementos, porém baixa razão sinal-ruído. Uma maneira eficiente e simples de contornar estas limitações é medir a mesma amostra por múltiplos métodos. Assim as deficiências de cada técnica são supridas pelas vantagens das outras. Contudo, de nada adianta obter vários espectros com informações complementares de uma mesma amostra, se eles não forem utilizados para obter uma solução única. O SIMNRA não permite o ajuste de vários espectros simultaneamente e, portanto, não é eficiente para análises múltiplas. O MultiSIMNRA foi programado com o intuito de cobrir as duas citadas limitações. Este programa funciona controlando múltiplas instâncias do SIMNRA simultaneamente. Ele permite lidar com um grande número de variáveis e ajustá-las todas concomitantemente, independentemente do número de camadas que formam a amostra em análise. Além disso, o ajuste de uma 


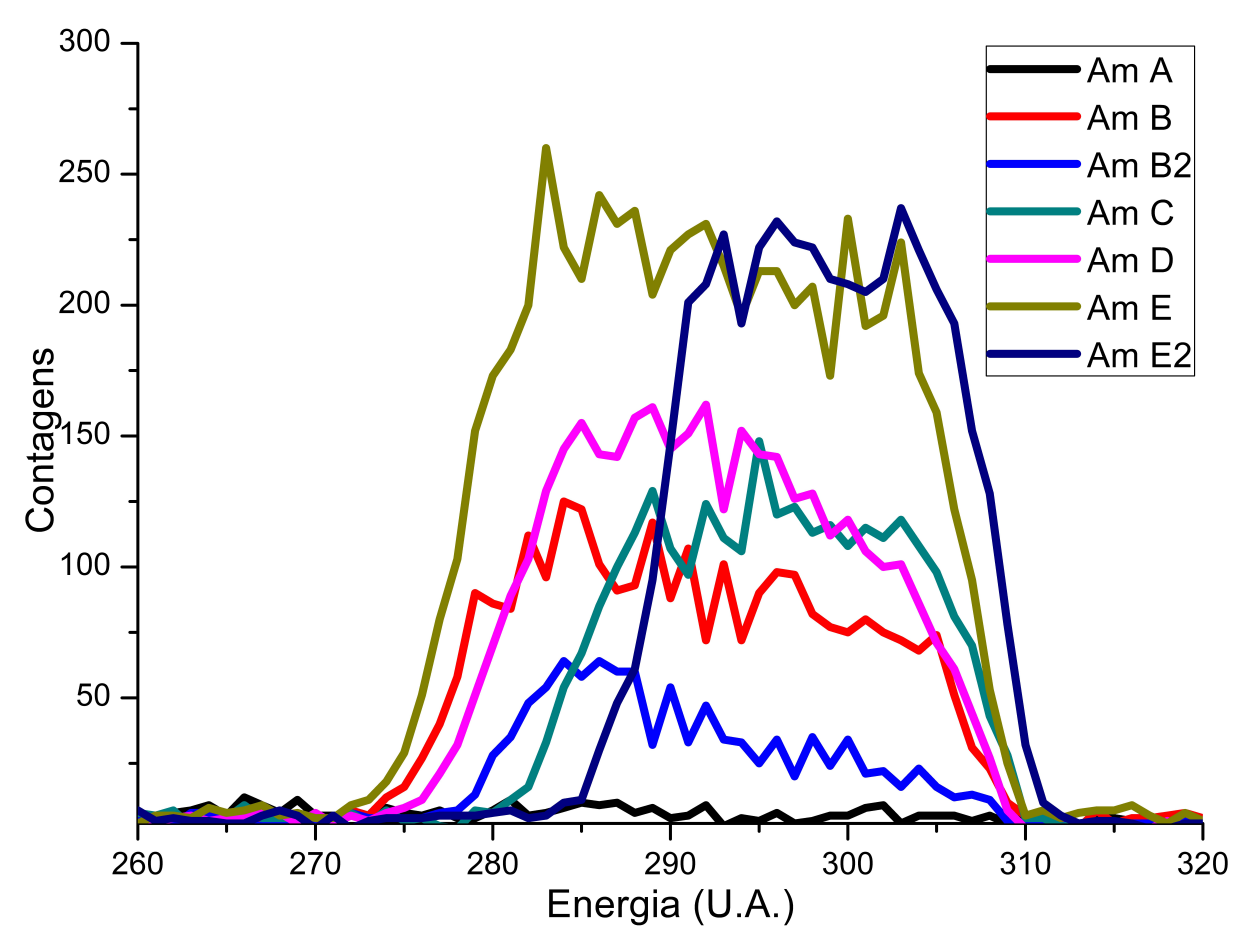

Figura 28 - Sinal referente à detecção de Ar obtido através do arranjo 4. Maiores energias de produção resultaram no aumento da saturação de Ar.

única amostra pode ser feito utilizando vários espectros. O MultiSIMNRA realiza ajustes através da minimização do $Q^{2}$ normalizado (somatória do quadrado dos resíduos reduzidos dividida pelo valor esperado de $Q^{2}$ ) (SILVA et al., 2016). Ele possui quatro métodos de optimização dos parâmetros. Assim como na análise por XRR, aqui foi utilizado o método simplex para todas as amostras.

De acordo com a tabela 3, seis diferentes tipos de espectros foram utilizados para fazer os ajustes dos filmes no MultiSIMNRA. A RBS e A EBS foram feitas com partículas alfa com 3,050 MeV. A vantagem em utilizar RBS com esta configuração reside no fato de que o modelo Rutherford de retroespalhamento funciona muito bem neste caso, levando a uma medição precisa da composição. A EBS feita com 3,050 MeV quantifica com precisão o oxigênio devido ao pico presente em 3,038 MeV na seção de choque deste elemento (figura 13). Ambas as técnicas foram empregadas inclinando a amostra a $7^{\circ}$ e a $80^{\circ}$. A inclinação de $80^{\circ}$, relativamente à de $7^{\circ}$, serve para melhorar a resolução de profundidade em detrimento da precisão da estequiometria.

Medidas de ERDA foram feitas duas vezes. Uma delas foi feita com feixe de oxigênio e inclinação de $60^{\circ}$ do filme. A medida com íons de oxigênio, devido ao alto freamento que partículas pesadas sofrem, possui altíssima resolução de profundidade relativamente às outras. Em contrapartida, ela não é muito bem descrita pelo modelo de retroespalhamento, 


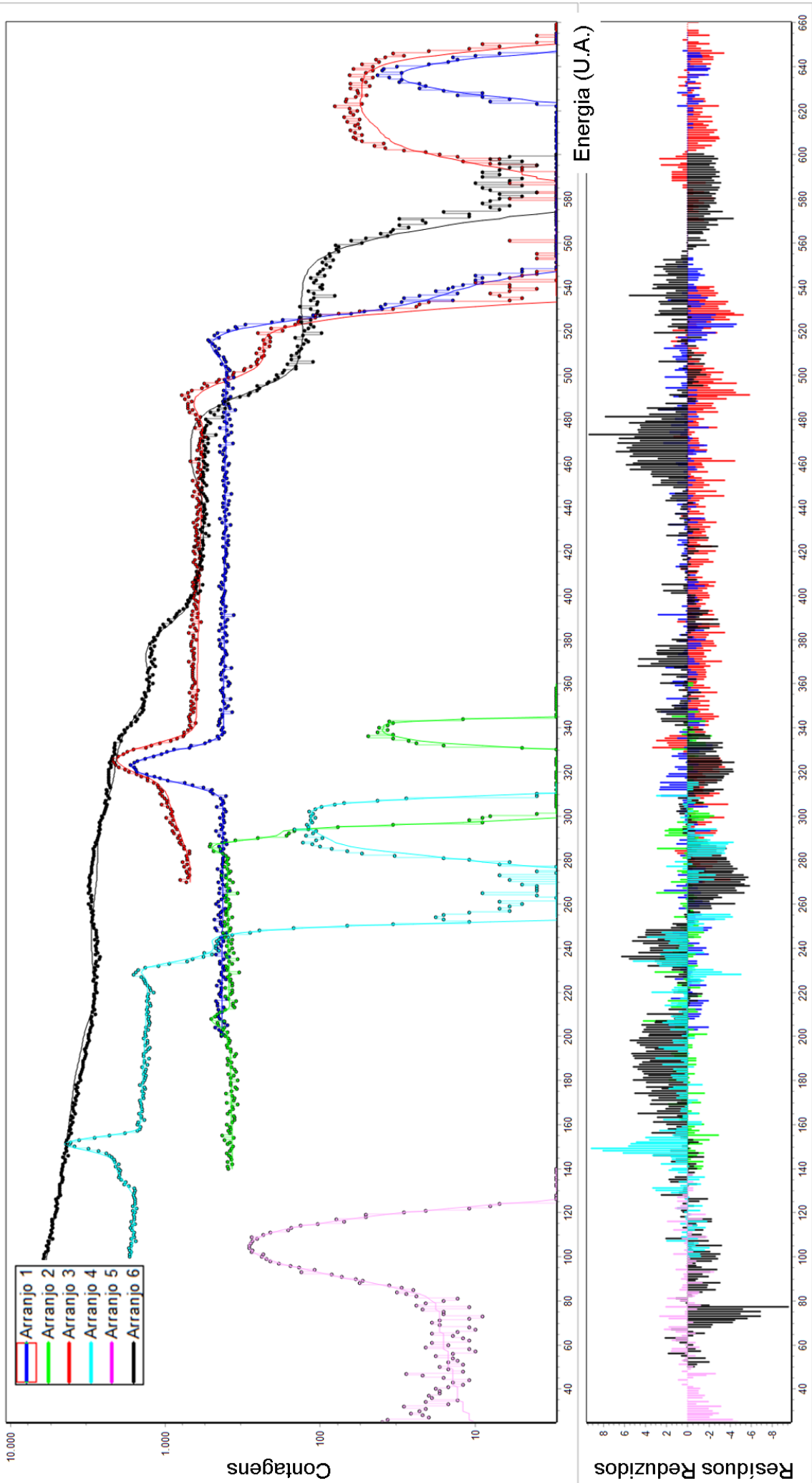

Figura 29 - Exemplo da análise múltipla que foi realizada em todas as amostras. A curva rosa foi obtida por ERDA com partículas alfa e a curva preta por ERDA com feixe de oxigênio. As demais curvas são resultados de RBS/EBS realizados com distintos ângulos de detecção e de inclinação de amostra. 
tornando a quantificação menos confiável. A segunda medida de ERDA foi feita com partículas alfa e inclinando a amostra em $80^{\circ}$. As partículas alfa possuem massa pequena, portanto elas conseguem causar recuo somente em átomos muito leves, principalmente átomos de $\mathrm{H}$ - único elemento mais leve que o próprio He. Por essa razão, medidas de ERDA com alfa servem exclusivamente para medir a concentração de hidrogênio. Lembrando que, como descrito na seção 3.5, na técnica de ERDA com alfa coloca-se uma folha de alumínio na frente do detector para impedir a detecção de quaisquer elementos distintos do $\mathrm{H}$.

As medidas de ERDA com feixe de oxigênio não estão muito bem ajustadas para nenhum filme. Isto acontece porque o modelo de espalhamento e recuo não funciona com a mesma qualidade para feixes de oxigênio e feixes de alfa. A massa e tamanho relativamente grandes dos átomos de oxigênio fazem com que as interações íon-núcleo sejam um pouco mais complicadas do que o modelo de Rutherford prevê. Um íon pesado pode se aproximar suficientemente do núcleo espalhador para que suas eletrosferas se sobreponham, alterando a natureza da colisão descrita em 2.5. Para ilustrar essa falha, foi feito um ajuste da amostra C utilizando somente a medida de ERDA com oxigênio. Os parâmetros da amostra assim obtidos foram utilizados para simular os espectros de RBS e EBS (figura 30). Esse procedimento deixa claro que as medidas de ERDA com O, apesar de possuírem boa resolução de profundidade, são limitadas devido aos modelos teóricos que descrevem o experimento. Essa comparação serve também para ilustrar a vantagem de se fazer uma análise múltipla: as deficiências de uma medida são percebidas pela qualidade dos demais espectros.

Os perfis de profundidade de todas as amostras têm alguns fatores em comum. Os filmes possuem concentração de hidrogênio não uniforme. Há pouco hidrogênio nas regiões da superfície e da interface filme-substrato. Os átomos de $\mathrm{H}$ estão mais presentes no meio do filme como mostra a figura 31. A razão $\mathrm{O} / \mathrm{Al}$ aumenta junto com o aumento da concentração de H. Em outras palavras, onde há mais H, há mais O. Isto não é prova, mas é indício de que os átomos de $\mathrm{H}$ estão ligados ao $\mathrm{O}$.

Outra característica que aparece em todas as amostras é a concentração uniforme de argônio. As amostras possuem concentrações diferentes de argônio (tabela 6), porém possuem em comum um perfil de profundidade constante deste elemento. Os dados mostram que a incorporação de Ar é maior para maiores energias.

Todas os ajustes mostram uma camada de óxido de silício entre o substrato e o filme de alumina. Isto é esperado, dado que o silício tem sua superfície naturalmente oxidada quando exposto ao ambiente. Contudo, a camada de óxido de silício obtida pelo MultiSIMNRA possui dezenas de nanômetros, não apenas unidades de nanômetros - o que seria esperado de uma camada natural de óxido de silício (MORITA et al., 1990). Além disso, os substratos foram devidamente lavados com ácido fluorídrico previamente à deposição para a remoção do óxido de silício. Portanto, é possível inferir que ao menos 


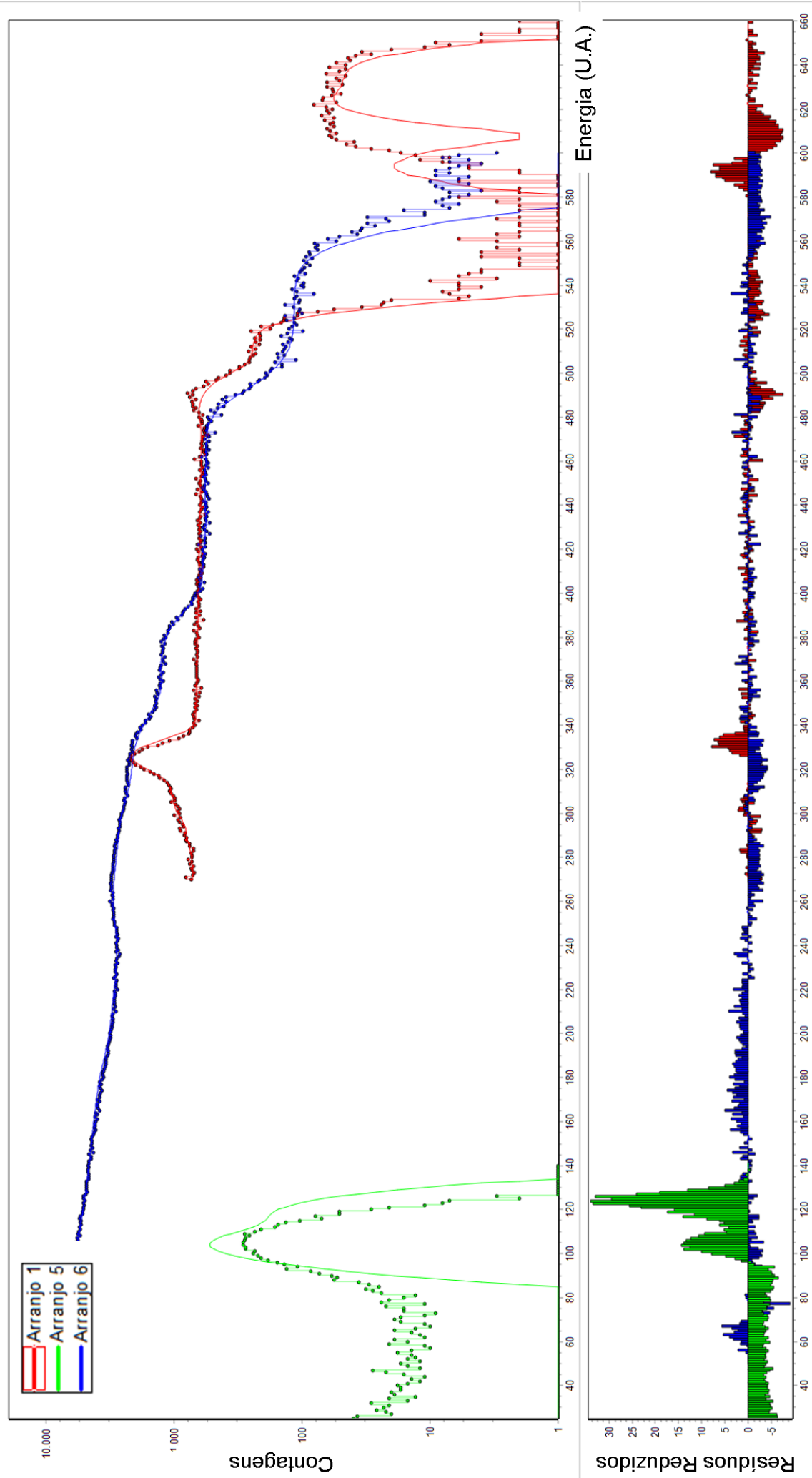

Figura 30 - A curva azul é um ajuste do espectro de ERDA obtido com feixe de oxigênio. O resultado deste ajuste foi utilizado para simular espectros de outros arranjos experimentais (curvas verde e vermelha). Isto ilustra que as medidas feitas com feixe de oxigênio são imprecisas. 

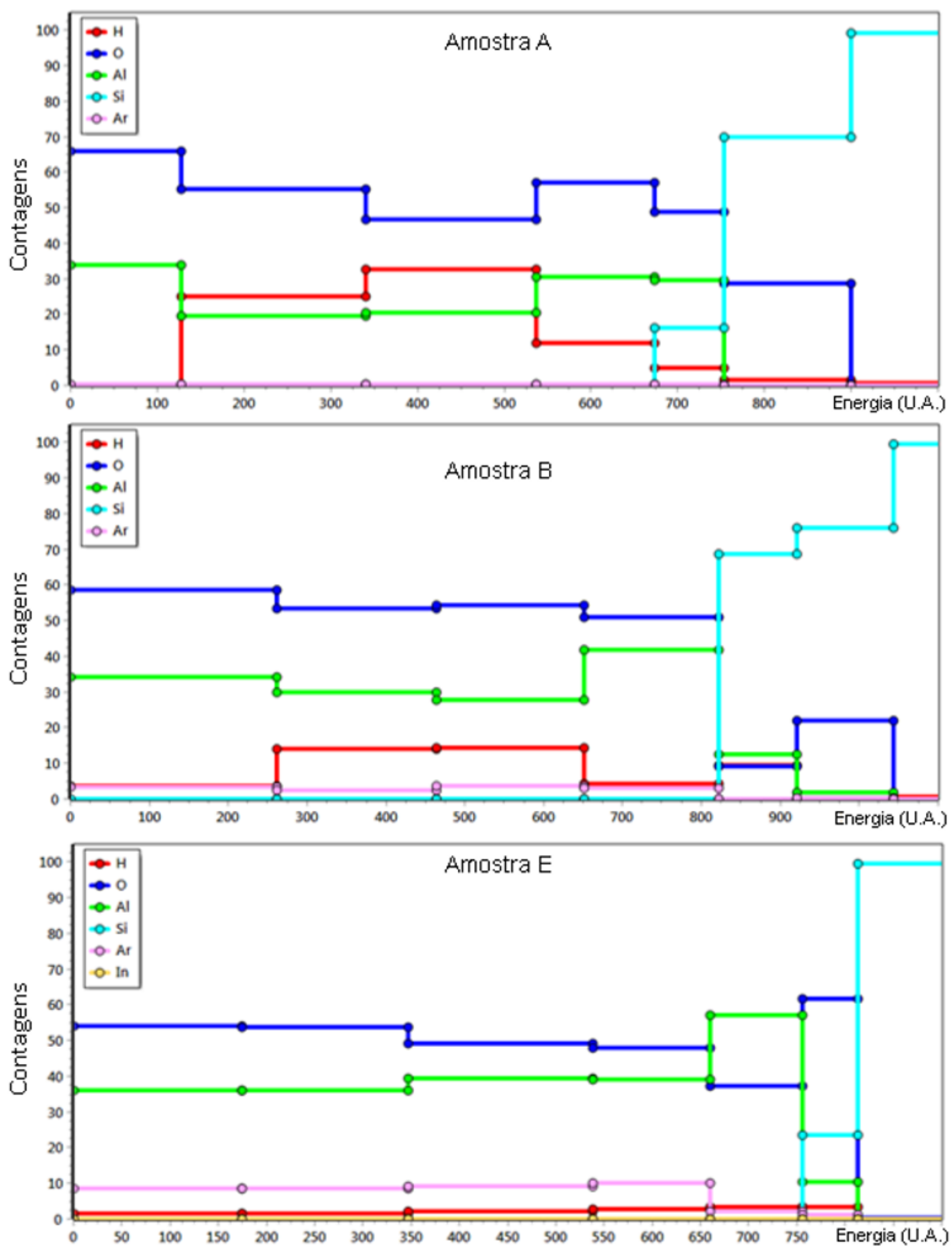

Figura 31 - Exemplos de perfis de profundidade obtidos pelo MultiSIMNRA. Observa-se que a presença de $\mathrm{H}$ não é uniforme; a concentração de $\mathrm{H}$ diminui com a energia de produção, enquanto a concentração de Ar aumenta. Detectou-se uma contaminação de 0,5 TFU de In na superfície da amostra D. 
Tabela 6 - Concentrações de Ar fornecidas pelo MultiSIMNRA

\begin{tabular}{cc}
\hline Amostra & Concentração de Ar (\%) \\
\hline A & 0,3 \\
B & 3,2 \\
B2 & 0,9 \\
C & 3,8 \\
D & 4,7 \\
E & 8,2 \\
E2 & 9,0 \\
\hline
\end{tabular}

parte do óxido de silício se forma durante a deposição da alumina ou posteriormente.

Existe uma peculiaridade que necessita ser apontada nos dados da amostra $\mathrm{A}$. $\mathrm{Na}$ figura 32 estão plotados os dados de RBS das amostras A e B. O sinal referente ao silício na amostra $\mathrm{A}$ começa mais à direita (com energia maior) relativamente à amostra $\mathrm{B}$. $\mathrm{O}$ deslocamento à direita, a princípio, indica que o silício está mais próximo da superfície na amostra A. Entretanto, esse resultado não é razoável. Não há uma boa explicação para a existência de átomos de silício na superfície do filme. Uma interpretação alternativa é a de que a amostra A possui rachaduras ou poros. Deste modo, parte do feixe de partículas alfa alcança o substrato sem passar pela espessura total do filme ou, até mesmo, sem passar pelo filme.

Os resultados da análise por feixes iônicos mostram que a proporção global (considerando o filme todo) entre oxigênio e alumínio é maior do que 1,5 para quase todas as amostras, exceto a E (figura 33). O aumento de energia do feixe de argônio diminuiu a concentração de hidrogênio e oxigênio nos filmes. A figura 33 mostra também a clara correlação entre a razão $\mathrm{O} / \mathrm{Al}$ e a presença de $\mathrm{H}$. Assumindo que todo hidrogênio presente nos filmes está na forma de moléculas de água, foi calculada uma razão corrigida de $\mathrm{O} / \mathrm{Al}$ considerando somente os átomos de oxigênio que não estão ligados a hidrogênios. Neste caso, a razão O/Al manteve-se compatível com 1,5 para as amostras de $150 \mathrm{eV}, 300 \mathrm{eV}$ e $600 \mathrm{eV}$ (B, C e D, respectivamente). A amostra produzida sem feixe (A) manteve o valor de $\mathrm{O} / \mathrm{Al}$ maior do que 1,5 e a amostra produzida com $900 \mathrm{eV}$ (E) apresentou razão O/Al abaixo de 1,5 .

O fato de a amostra $\mathrm{A}$ possuir razão $\mathrm{O} / \mathrm{Al}>1,5$ é indício de que esse filme pode possuir outras moléculas além de $\mathrm{Al}_{2} \mathrm{O}_{3}$ e $\mathrm{H}_{2} \mathrm{O}$, como, por exemplo, o hidróxido de alumínio $\left[\mathrm{Al}(\mathrm{OH})_{3}\right]$ ou o óxido hidróxido de alumínio $[\mathrm{AlO}(\mathrm{OH})]$. A baixa razão $\mathrm{O} / \mathrm{Al}$ da amostra E evidencia que a assistência do feixe de $\mathrm{Ar}^{+}$com $900 \mathrm{eV}$ causa relevante sputtering preferencial do oxigênio. Esta amostra possivelmente possui pequena quantidade de alumínio metálico. 


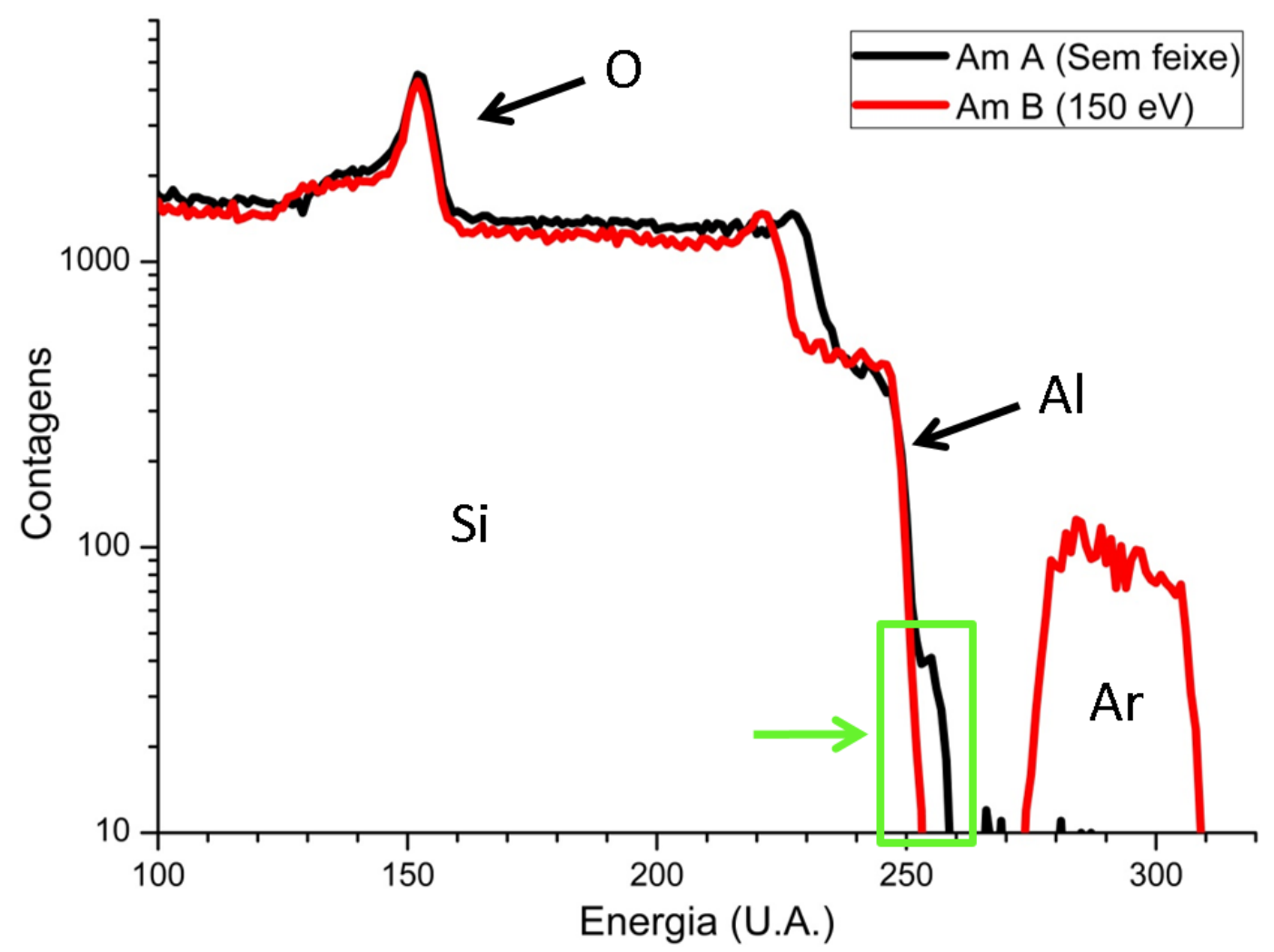

Figura 32 - Espectros de RBS/EBS das amostras A e B obtidos pelo arranjo 4. As contagens da curva preta obtidas na região de energia entre 250 U.A. e 260 U. A. indicam que a amostra A possui pequenas rachaduras.

\subsection{Incertezas}

Naturalmente, como em todo trabalho de física experimental, as comparações entre os resultados estão limitadas pelas incertezas das medidas. Portanto, é necessário discutir as incertezas provenientes das técnicas de caracterização utilizadas. A única análise quantitativa feita através do método AFM foi a de rugosidade. As incertezas dos resultados de Rrms foram calculadas pelo procedimento padrão, isto é, repetiu-se a medida algumas vezes para cada amostra e, a partir desses dados, calculou-se a flutuação estatística (desvio padrão e desvio padrão da média) da rugosidade. Cada amostra teve ao menos 5 imagens tomadas para a estimativa da incerteza.

Estimar as incertezas dos resultados obtidos por análise de feixes iônicos e XRR não é tão simples quanto no caso da AFM. As informações resultantes da XRR (espessura, composição e etc.) são extraídas através de ajustes de funções aos dados brutos. Os dados brutos (intensidade de raios-x e ângulo de detecção) possuem incerteza bem definida. Portanto, as incertezas finais podem ser calculadas via propagação de incertezas. Contudo, as funções que conectam os dados brutos aos numerosos parâmetros de ajuste são extremamente complicadas, tornando a propagação de incertezas uma tarefa impraticável. Uma alternativa é simular a flutuação estatística dos parâmetros resultantes do ajuste 


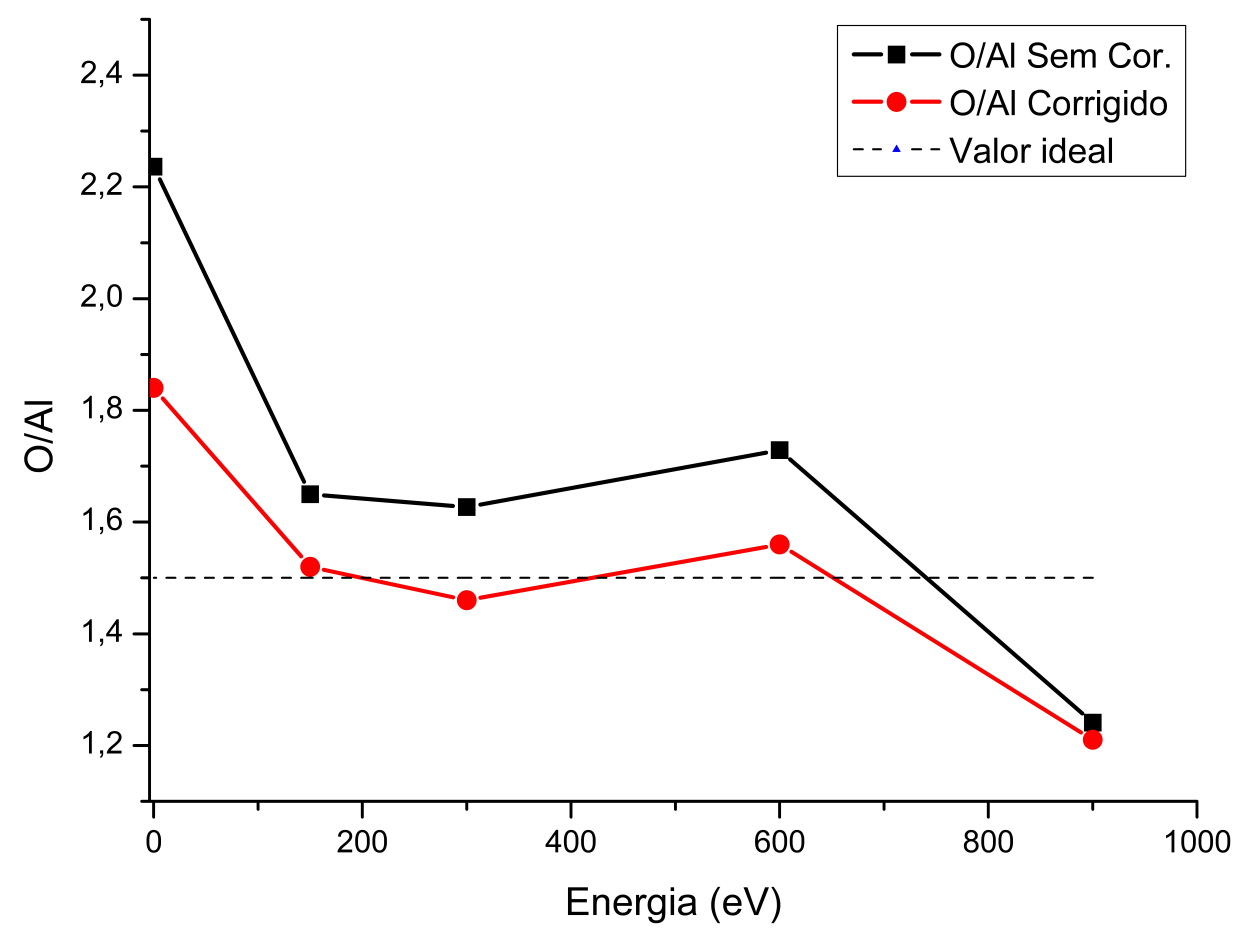

Figura 33 - Razão O/Al das amostras A, B, C, D e E. A curva preta fornece a razão bruta. Os pontos da curva vermelha foram calculados sem levar em conta os átomos de $\mathrm{O}$ que estão ligado com $\mathrm{H}$ e supondo que estes se ligam na forma $\mathrm{H}_{2} \mathrm{O}$.

(PRESS et al., 1992c). O software MultiSIMNRA utiliza essa alternativa de maneira muito eficiente. Em síntese, o software utiliza o seguinte procedimento para estimar as incertezas: (1) o usuário fornece ao programa um intervalo de confiança para simular a flutuação (por exemplo, 68,3\%, valor referente ao intervalo de 1 desvio padrão em distribuições normais); (2) o software associa este percentual a um intervalo de confiança de $Q^{2}$, ou seja, estabelece um $\Delta Q^{2}$; (3) valores dos parâmetros de ajuste são sorteados via método de Monte Carlo; (4) cada novo sorteio é avaliado para verificar se os parâmetros sorteados residem no intervalo $\Delta Q^{2} ;(5)$ se o resultado estiver fora do intervalo, ele é descartado; (6) repete-se o procedimento até que haja um número $N$ (estabelecido pelo usuário) de resultados sorteados; (7) finalmente, os resultados não descartados são utilizados para estimar a flutuação estatística dos parâmetros obtidos pelo ajuste.

Um exemplo dessas simulações de Monte Carlo está na figura 34. Ele foi construído com intervalo de confiança de $68,3 \%$ e 40.000 sorteios válidos. A figura mostra que o argônio foi quantificado com precisão da ordem de 1\%. Os outros elementos têm incertezas de concentração variando entre $3 \%$ e 5\%, dependendo da espessura e da composição da camada. A resolução de espessura é aproximadamente 75 TFU, portanto, resultados dos ajuste com espessura menor do que 75 TFU não constituem informações válidas de composição. 


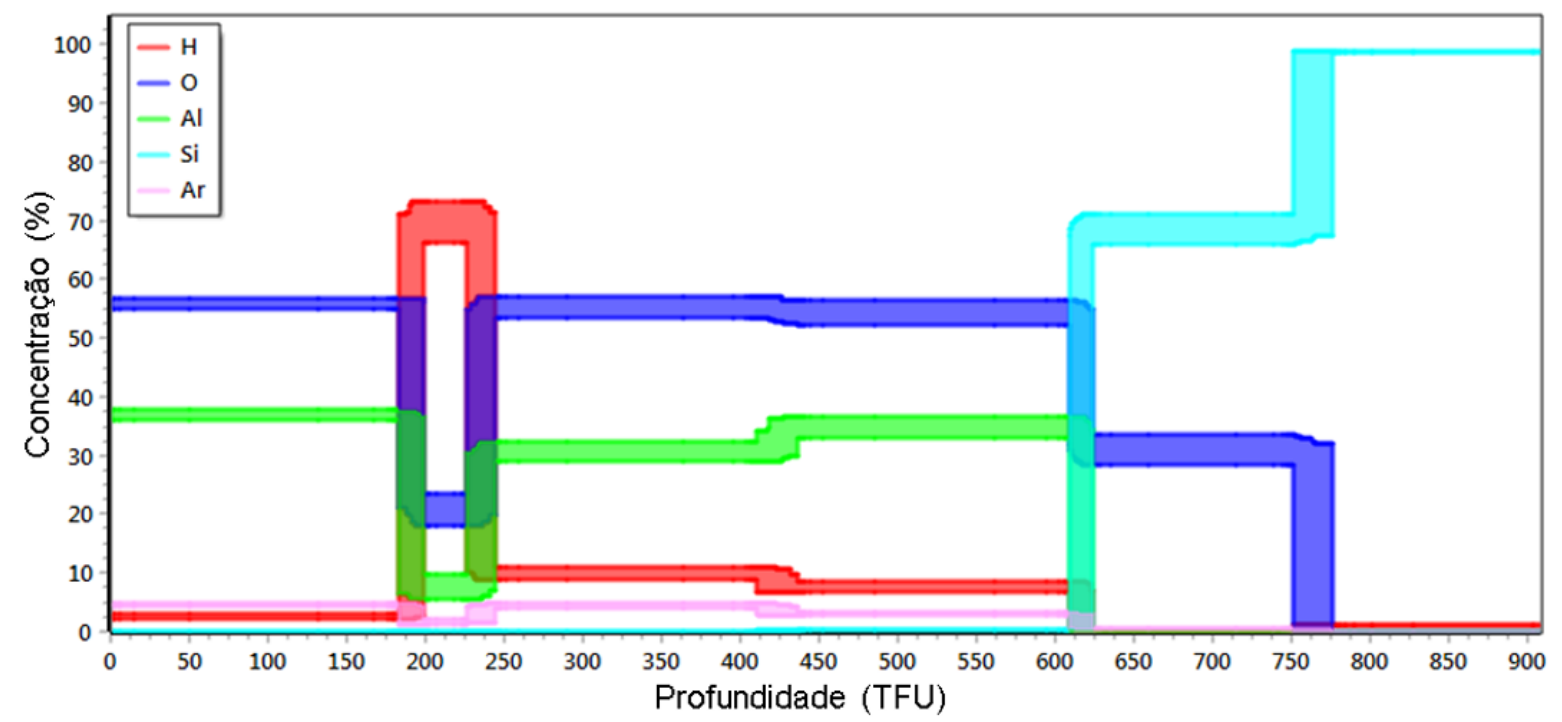

Figura 34 - Perfil de profundidade com incertezas da amostra C. A camadas entre 200 TFU e 250 TFU possui espessura menor do que a resolução das medidas e, portanto, não fornece informação confiável.

O software GenX calcula as incertezas variando a $F M$ em 5\%. Esta estimativa leva a incertezas de densidade de 0,0001\%, que são nitidamente subestimadas. Uma estimativa mais realista consiste em propagar a incerteza do ângulo crítico para a densidade eletrônica através da equação 2.12. Sabendo que a resolução angular do equipamento utilizado nas medidas de XRR é $0,01^{\circ}$, e assumindo metade desse valor como incerteza angular, a incerteza da densidade eletrônica é da ordem de 4\%. Tal precisão é suficiente para validar a conclusão, obtida a partir dos ângulos críticos (figura 23), de que a amostra produzida sem feixe é menos densa do que as amostras produzidas com feixe de $\mathrm{Ar}^{+}$.

Os dados experimentais utilizados no GenX possuem outras fontes de erro além da precisão angular. Portanto, é compreensível que nenhuma correlação entre os resultados obtidos pelo ajuste de refletividade e os parâmetros de produção do filme foi encontrada: as variações de rugosidade e densidade resultantes da assistência do feixe iônico são menores do que a precisão do resultado obtidos através do ajuste de refletividade.

\subsection{Comparações entre as técnicas}

O gráfico da figura 35 foi construído com o objetivo de comparar as rugosidades obtidas por AFM com aquelas obtidas por XRR. No eixo das ordenadas estão os valores de $R_{r m s}$ obtidos por AFM; as coordenadas são os valores de $R_{r m s}$ obtidos por XRR. Os métodos forneceram rugosidades com mesma ordem de grandeza (entre $1 \AA$ e $9 \AA$ ), porém sem correlação aparente. A ausência de correlação é explicada pela presença de erros não estatísticos nos resultados do ajuste de refletividade.

As espessuras dos filmes foram obtidas pelos ajustes do MultiSIMNRA e do GenX. 


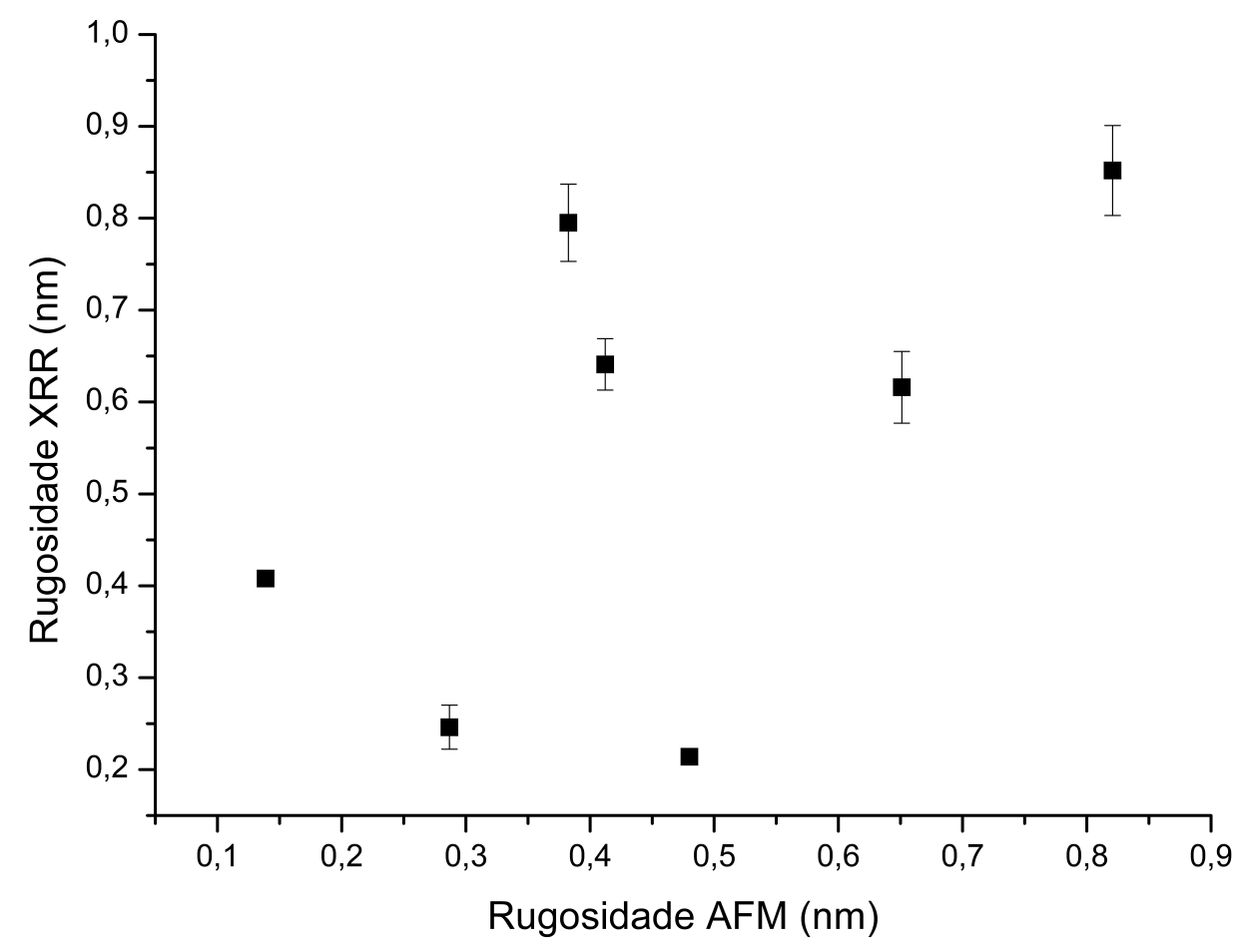

Figura 35 - Comparação entre as rugosidade obtidas por XRR e por AFM. A ordem de grandeza das medidas é compatível, mas não há correlação aparente.

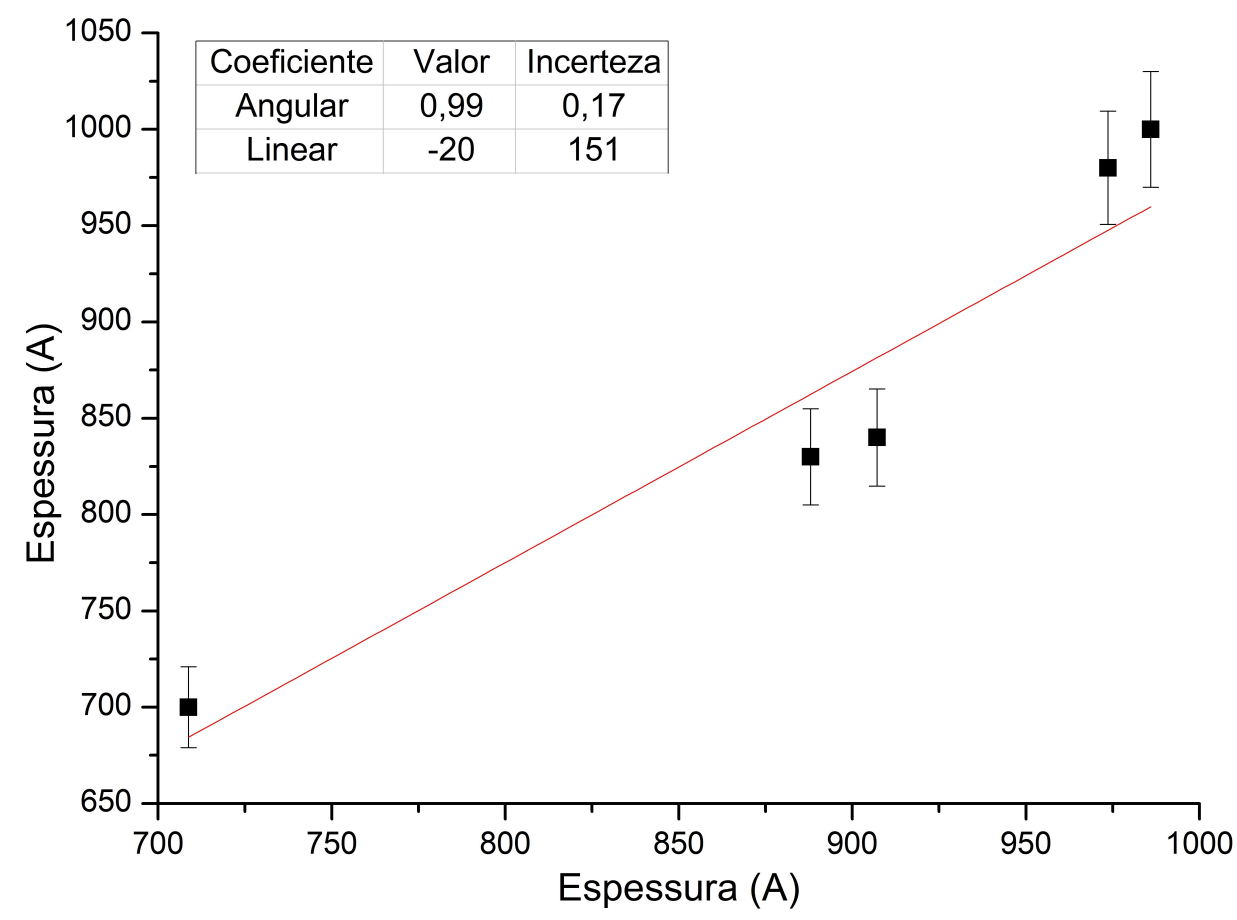

Figura 36 - Comparação entre as espessuras obtidas por XRR (coordenadas) e por IBA (ordenadas). A espessura em $\AA$ proveniente da IBA foi calculada assumindo a densidade resultante da XRR. 
A análise de feixes iônicos fornece a espessura em TFU $\left(10^{15}\right.$ at. $\left./ \mathrm{cm}^{2}\right)$; a XRR obtém a espessura em unidades de comprimento ( $\AA$ ou nm). Transformar TFU em unidades de comprimento exige conhecer a densidade da amostra. Portanto, as densidades calculadas através do ângulo crítico de refletividade (figura 23) foram utilizadas para converter em nanômetros as espessuras fornecidas pelo MultiSIMNRA. Na figura 36 estão plotados os dados de espessura obtidos por XRR (coordenadas) e pela análise de feixes iônicos (ordenadas). A relação entre os dois conjuntos de dados é bem descrita por uma reta com coeficiente angular muito próximo da unidade.

Os dados de AFM, XRR e análise for feixes iônicos apontam algo em comum: a amostra A, produzida sem feixe, possui a pior qualidade entre todas as amostras. A AFM aponta que o filme A não possui superfície homogênea e é relativamente rugoso. A análise por feixes iônicos mostra que o filme A possui alta concentração de hidrogênio e falhas na superfície. A XRR informou que ele é o menos denso de todos. Essas informações são coerentes entre si, afinal, espera-se que um filme com alta (e não uniforme) concentração de hidrogênio seja pouco denso, possua alta rugosidade e tenha falhas. 


\section{Conclusões}

(1) Todos os filmes são amorfos ou possuem cristalitos menores do que a capacidade de detecção do difratômetro. Nem mesmo a combinação de bombardeamento com feixe de argônio com $900 \mathrm{eV}$ e aquecimento a $450{ }^{\circ} \mathrm{C}$ foi suficiente para produzir amostras cristalinas.

(2) Os filmes com superfície menos rugosa foram aqueles produzidos com energia dentre $300 \mathrm{eV}$ e $600 \mathrm{eV}$. O aquecimento in situ abaixou a rugosidade da amostra produzida com $900 \mathrm{eV}$.

(3) O tamanho dos grãos aumenta conforme a energia de deposição aumenta. Comparando as amostras E e E2, observou-se que a segunda, produzida à temperatura de $450{ }^{\circ} \mathrm{C}$, possui grãos maiores do que a primeira.

(4) Todas as amostras possuem densidade muito menor que a esperada para a alumina $\left(3,97 \mathrm{~g} / \mathrm{cm}^{3}\right)$ e espessura maior do que a estimada in situ (60 $\left.\mathrm{nm}\right)$.

(5) O bombardeamento iônico aumenta a densidade dos filmes. Não houve variação detectável de densidade com o aumento de energia do feixe ou com a temperatura de deposição.

(6) O perfil de profundidade do SLD mostra alta densidade eletrônica na superfície dos filmes, filmes homogêneos e existência de camada intermediária entre filme e substrato.

(7) A combinação de análise por XRR e por feixes iônicos fornece confiáveis medidas de espessura.

(8) Todos os filmes possuem uma camada de óxido de silício entre filme e substrato mais espessa do que a camada de óxido que naturalmente se forma sobre o silício.

(9) A concentração de $\mathrm{H}$ e de $\mathrm{O}$ diminuem com o aumento da energia de produção.

(10) A concentração de $\mathrm{H}$ em função da profundidade não é uniforme.

(11) A concentração de Ar em função da profundidade é constante em todas as amostras.

(12) Quanto maior a energia de produção, mais Ar há nos filmes.

(13) Os filmes com melhor estequiometria são aqueles produzidos com energia dentre $150 \mathrm{eV}$ e $600 \mathrm{eV}$.

(14) Através da assistência do feixe iônico de Ar é possível aumentar a densidade, diminuir a presença de hidrogênio, controlar a rugosidade e controlar a estequiometria dos filmes finos de alumina. 
(15) A ARR utilizada para produzir a amostra B2 $(0,7)$ não é suficiente para melhorar a rugosidade e eliminar $\mathrm{H}$ dos filmes.

(16) O filme produzido sem assistência de feixe iônico possui características indesejadas: heterogeneidade, alta rugosidade, alta concentração de H, menor densidade e rachaduras.

(17) Os filmes com melhor qualidade - com baixa rugosidade, estequiometria adequada, pouco $\mathrm{H}$ e boa densidade - foram produzidos com energias dentre $150 \mathrm{eV}$ e 600 $\mathrm{eV}$ (amostras B, C e D). 


\section{Referências}

AL-ROBAEE, M. S. et al. Studies of the optical and structural properties of ion-assisted deposited $\mathrm{Al}_{2} \mathrm{O}_{3}$ thin films. Vacuum, v. 45, n. 1, p. 97-102, 1994. ISSN 0042207X. Citado na página 6.

BIERSACK, J. P.; BERG, S.; NENDER, C. T-DYN Monte Carlo simulations applied to ion assisted thin film processes. Nuclear Inst. and Methods in Physics Research, B, v. 59-60, n. PART 1, p. 21-27, 1991. ISSN 0168583X. Citado na página 9.

BINNIG, G.; QUATE, C. F. Atomic Force Microscope. Physical Review Letters, v. 56, n. 9, p. 930-933, 1986. ISSN 0031-9007. Citado na página 13.

BJÖRCK, M.; ANDERSSON, G. GenX: An extensible X-ray reflectivity refinement program utilizing differential evolution. Journal of Applied Crystallography, v. 40, n. 6, p. 1174-1178, 2007. ISSN 00218898. C Citado na página 43.

BROCK, D. C.; LAWS, D. A. The early history of microcircuitry: An overview. IEEE Annals of the History of Computing, v. 34, n. 1, p. 7-19, 2012. ISSN 10586180. Citado na página 4.

BUBERT, H.; JENNET, H. Surface and Thin Films Analysis: a compendium of principles, instrumentations, and application. [S.l.]: WILEY-VCH, 2003. P. 277-284. Citado 4 vezes nas páginas 13, 25, 28 e 30.

CAO, X. Q.; VASSEN, R.; STOEVER, D. Ceramic materials for thermal barrier coatings. Journal of the European Ceramic Society, v. 24, n. 1, p. 1-10, 2004. ISSN 09552219.

Citado na página 6.

CAPPELLA, B.; DIETLER, G. Force-distance curves by atomic force microscopy. Surface Science Reports, v. 34, n. 1, p. 1-104, 1999. ISSN 01675729. Citado na página 13.

CHIEN, A. A.; KARAMCHETI, V. Moore's law: The first ending and a new beginning. Computer, v. 46, n. 12, p. 48-53, 2013. ISSN 00189162. Citado na página 5.

CHINAGLIA, E. Caracterização nanoestrutural de filmes finos do grupo IV-B depositados por sputtering magnetron. Tese (Doutorado) - Universidade de São Paulo, 2002. Citado 4 vezes nas páginas 15, 12, 35 e 41.

CULliTY, B. D.; STOCK, S. R. Elements of X-Ray Diffraction. third. [S.l.]: Prentice Hall, 2001. Cap. 5; p. 167. Citado 3 vezes nas páginas 15, 18 e 39.

CULliTY, B. D.; STOCK, S. R. Elements of X-Ray Diffraction. third. [S.l.]: Prentice Hall, 2001. Cap. 3 - p. 95. Citado na página 17.

CULliTY, B. D.; STOCK, S. R. Elements of X-Ray Diffraction. third. [S.l.]: Prentice Hall, 2001. Cap. 2-p. 35. Citado na página 17.

CULliTY, B. D.; STOCK, S. R. Elements of X-Ray Diffraction. third. [S.l.]: Prentice Hall, 2001. Cap. 5; p. 182. Citado na página 18. 
DREXLER, K. Molecular engineering An approach to the development of general capabilities for molecular manipulation. Proceedings of the National Academy of Sciences of the United States of America, v. 78, n. 9, p. 5275-8278, 1981. ISSN 00134651. Citado na página 4 .

EDY, R. et al. Influence of argon plasma on the deposition of $\mathrm{Al}_{2} \mathrm{O}_{3}$ film onto the PET surfaces by atomic layer deposition. Nanoscale Research Letters, v. 8, n. 79, 2013. ISSN 1932-7447. Disponível em: <http://pubs.acs.org/doi/abs/10.1021/jp406738h>. Citado na página 6.

EVERTSSON, J. et al. The thickness of native oxides on aluminum alloys and single crystals. Applied Surface Science, Elsevier B.V., v. 349, p. 826-832, 2015. ISSN 01694332. Disponível em: <http://dx.doi.org/10.1016/j.apsusc.2015.05.043>. Citado na página 3.

GIBAUD, A.; VIGNAUD, G. Specular Reflectivity from Smooth and Rough Surfaces. [S.1.]: Lecture Notes in Physics, 2009. Cap. 3; p. 87. Citado na página 19.

GIBAUD, A.; VIGNAUD, G. Specular Reflectivity from Smooth and Rough Surfaces. [S.l.]: Lecture Notes in Physics, 2009. Cap. 3; p. 91. Citado na página 22.

GREENE, J. E. Tracing the 5000-year recorded history of inorganic thin films from $~ 3000$ BC to the early 1900s AD. Applied Physics Reviews, v. 1, n. 4, p. 041302, 2014. ISSN 1931-9401. Disponível em: <http://scitation.aip.org/content/aip/journal/apr2/1/4/10. 1063/1.4902760>. Citado na página 1.

GURBICH, A. F. SigmaCalc recent development and present status of the evaluated cross-sections for IBA. Nuclear Instruments and Methods in Physics Research, Section B: Beam Interactions with Materials and Atoms, Elsevier B.V., v. 371, p. 27-32, 2016. ISSN 0168583X. Disponível em: <http://dx.doi.org/10.1016/j.nimb.2015.09.035>. Citado 3 vezes nas páginas 15, 26 e 50.

HUFF, H. Into The Nano Era: Moore's Law Beyond Planar Silicon CMOS. [S.1.]: Springer, 2009. ISBN 9783540745587. Citado na página 5.

HUNTER, M. S.; FOWLE, P. Determination of Barrier Layer Thickness of Anodic Oxide Coatings. Journal of The Electrochemical Society, v. 101, n. 9, p. 481-485, 1954. ISSN 00134651. Disponível em: <http://jes.ecsdl.org/content/101/9/481.abstract>. Citado na página 3.

HUNTER, M. S.; FOWLE, P. Natural and Thermally Formed Oxide Films on Aluminum. Journal of The Electrochemical Society, v. 103, n. 9, p. 482, 1956. ISSN 00134651.

Disponível em: <http://jes.ecsdl.org/cgi/doi/10.1149/1.2430389>. Citado na página 3.

HWANG, Y. et al. Synchrotron X-ray reflectivity study of high dielectric constant alumina thin films prepared by atomic layer deposition. Thin Solid Films, v. 510, n. 1-2, p. 159-163, 2006. ISSN 00406090. Citado na página 48.

JALILI, N.; LAXMINARAYANA, K. A review of atomic force microscopy imaging systems: Application to molecular metrology and biological sciences. Mechatronics, v. 14, n. 8, p. 907-945, 2004. ISSN 09574158. Citado na página 13. 
KYRYLOV, O.; KURAPOV, D.; SCHNEIDER, J. Effect of ion irradiation during deposition on the structure of alumina thin films grown by plasma assisted chemical vapour deposition. Applied Physics A, v. 80, n. 8, p. 1657-1660, 2005. ISSN 0947-8396. Citado na página 6.

LEKNER, J. Theory of Reflection, Reflection and Transmission of Electromagnetic, Particle and Acoustic Waves. second. [S.l.]: Springer, 2016. Citado na página 23.

LU, J.; LEE, E.; THOMAS, R. The analysis and interpretation of neutron and X-ray specular reflection. Acta Crystallographica Section A, v. 52, p. 11-41, 1996. ISSN 01087673. Citado na página 19.

MAGONOV, S. N.; WAHNGBO, M.-H. Surface Analysis with STM and AFM: Experimental and Theoretical Aspects of Image Analysis. [S.l.]: VCH, 1996. Citado 2 vezes nas páginas 15 e 12 .

MANNERS, D. Samsung, TSMC hit by poor 10nm yields. Electronics Weekly, 2016. Disponível em: <http://www.electronicsweekly.com/news/business/ samsung-tsmc-hit-poor-10nm-yields-2016-12/> . Citado na página 5.

MAYER, M. SIMNRA User's Guide. [S.l.: s.n.], 2011. Citado na página 50.

MOHAN, S.; KRISHNA, M. G. A Review of Ion Beam Assisted Deposition of Optical Thin Films. Vacuum, v. 46, n. 7, p. 645-659, 1995. ISSN 0042207X. Citado 2 vezes nas páginas 9 e 10.

MOORE, G. Cramming More Components Onto Integrated Circuits. Electronics, v. 38, n. 8, p. 82-85, 1965. ISSN 00134651. Disponível em: <http://jes.ecsdl.org/cgi/doi/10. 1149/1.2430389>. Citado na página 5.

MOORE, G. Progress In Digital Integrated Electronics [Technical literaiture, Copyright 1975 IEEE. Reprinted, with permission. Technical Digest. International Electron Devices Meeting, IEEE, 1975, pp. 11-13.]. IEEE Solid-State Circuits Newsletter, v. 20, n. 3, p. 36-37, 1975. ISSN 1098-4232. Disponível em: <http: //ieeexplore.ieee.org/lpdocs/epic03/wrapper.htm?arnumber $=4804410>$. Citado na página 5.

MORITA, M. et al. Growth of native oxide on a silicon surface. Journal of Applied Physics, v. 68, n. 3, p. 1272-1281, 1990. ISSN 00218979. Citado 2 vezes nas páginas 3 e 54.

MORO, M. Estudo de técnicas de feixes iônicos para a quantificação do elemento químico boro. Tese (Doutorado) — Universidade de São Paulo, 2013. Citado 3 vezes nas páginas 15,25 e 37.

MOTT, N. The theory of the formation of protective oxide films on metals. Transactions of the Faraday Society, v. 43, p. 429-434, 1946. Citado na página 3.

NYSSONEN, D.; LANDSTEIN, L.; COOMBS, E. Two-dimensional atomic force microprobe trench metrology system. J. Vac. Sci. Technol. B, v. 9, n. 6, p. 3612, 1991. ISSN 0734211X. Citado na página 14.

OHRING, M. Materials Science of Thin Films. second. [S.1.]: Academic Press, 2001.

Citado na página 7. 
OTT, A. W. et al. Atomic layer controlled deposition of $\mathrm{Al}_{2} \mathrm{O}_{3}$ films using binary reaction sequence chemistry. Applied Surface Science, v. 107, p. 128-136, 1996. ISSN 01694332. Citado na página 43.

PHILIP, A. Preparation and characterization of High $k$ Aluminum Oxide Thin Films by Atomic Layer Deposition for Gate Dielectric applications. Tese (Doutorado) - Cochin University of Science and Technology, 2012. Citado na página 5.

PRESS, W. et al. Numerical Recipes in $C$ The Art of Scientific Computing. 2. ed. [S.1.]: Cambridge University Press, 1992. Cap 15 - p.656. Citado na página 46.

PRESS, W. et al. Numerical Recipes in C The Art of Scientific Computing. 2. ed. [S.1.]: Cambridge University Press, 1992. Cap 10 - p.408. Citado na página 47.

PRESS, W. et al. Numerical Recipes in C The Art of Scientific Computing. 2. ed. [S.l.]: Cambridge University Press, 1992. Cap 15 - p.689. Citado na página 59.

RIORDAN, M. The invention of the transistor. Proceedings of the IEEE, v. 86, n. 1, p. 7-28, 1998. ISSN 00189219. Citado 2 vezes nas páginas 4 e 5.

SALEEM, M. R. et al. Thermal properties of thin $\mathrm{Al}_{2} \mathrm{O}_{3}$ films and their barrier layer effect on thermo-optic properties of $\mathrm{TiO}_{2}$ films grown by atomic layer deposition. Thin Solid Films, Elsevier B.V., v. 542, p. 257-262, 2013. ISSN 00406090. Disponível em: $<$ http://dx.doi.org/10.1016/j.tsf.2013.06.030>. Citado na página 6.

SILVA, T. F. et al. MultiSIMNRA: A computational tool for self-consistent ion beam analysis using SIMNRA. Nuclear Instruments and Methods in Physics Research, Section B: Beam Interactions with Materials and Atoms, Elsevier B.V., v. 371, p. 86-89, 2016. ISSN 0168583X. Disponível em: <http://dx.doi.org/10.1016/j.nimb.2015.10.038>. Citado na página 52 .

SMIDT, F. A. Use of ion beam assisted deposition to modify the microstructure and properties of thin films. International Materials Reviews, v. 35, n. 1, p. 61-128, 1990. ISSN 0950-6608. Disponível em: <http://www.tandfonline.com/doi/full/10.1179/ 095066090790323975>. Citado 4 vezes nas páginas 7, 8, 9 e 10.

SONG, L. et al. $\mathrm{Al}_{2} \mathrm{O}_{3}$ Films with Ni-Based Buffer Layer Prepared By Plasma-Ion Assisted Deposition on Cu Substrate. Journal of Coatings Technology and Research, v. 3, n. 3, p. 237-240, 2006. Citado na página 6.

STEINHEIL, A. Struktur und Wachstum dünner Oberflächenschichten auf Metallen bei Oxydation an Luft. Annalen der Physik, v. 411, n. 5, p. 465-483, 1932. Citado na página 3.

THORNTON, S. T.; REX, A. Modern Physics for Scientists and Engineers: 4th edition. 4. ed. [S.l.]: Cengage Learning, 2013. 165-167 p. Citado 2 vezes nas páginas 15 e 27.

TOURNEY, C. Apostolic succession. Engineering and Science, v. 1, n. 2, p. 16-23, 2005. ISSN 0014-5246. Disponível em: < http://calteches.library.caltech.edu/4129/1/Succession. pdf $>$. Citado na página 4.

TRUEBA, M.; TRASATTI, S. P. $\gamma$-alumina as a support for catalysts: A review of fundamental aspects. European Journal of Inorganic Chemistry, n. 17, p. 3393-3403, 2005. ISSN 14341948. Citado na página 6. 
TURING, A. M. On computable numbers, with an application to the entscheidungsproblem. a correction. Proceedings of the London Mathematical Society, s2-43, n. 1, p. 544-546, 1938. ISSN 1460244X. Citado na página 2.

VENABLES, J. A.; SPILLER, G. D. T.; HANBUCKEN, M. Nucleation and growth of thin films. Reports on Progress in Physics, v. 47, n. 4, p. 399, 1984. ISSN 0034-4885.

Disponível em: <http://stacks.iop.org/0034-4885/47/i=4/a=002>. Citado 2 vezes nas páginas 15 e 8.

VERNON, W. Second experimental report to the atmospheric corrosion research comitte. Transactions of the Faraday Society, v. 23, p. 113-183, 1927. Citado na página 3.

VOIGTLÄNDER, B. Scanning Probe Microscopy: Atomic Force Microscopy and Scanning Tunneling Microscopy. [S.l.]: Springer, 2015. (NanoScience and Technology). Citado 2 vezes nas páginas 15 e 12 .

WEISSMANTEL, C. Reactive film preparation. Thin Solid Films, v. 32, p. 11-18, 1976. Citado 2 vezes nas páginas 9 e 10.

WESTRA, K.; MITCHELL, A.; THOMSON, D. Tip artifacts in atomic force microscope imaging of thin film surfaces. Journal of Applied Physics, v. 74, n. 5, p. 3608-3610, 1993. ISSN 00218979. Disponível em: < http://scitation.aip.org/content/aip/journal/jap/82/11/ 10.1063/1.366454>. Citado na página 14.

YASAKA, M. X-ray reflectivity measurement. The Rigaku Journal, v. 26, n. 2, 2010. ISSN 0038075X. Disponível em: < http://journals.lww.com/soilsci/Fulltext/2002/08000/ Evaluating $\left\{\_\right\}$Aeration $\left\{\backslash \_\right\}$Criteria $\left\{\backslash \_\right\}$By $\left\{\backslash \_\right\}$Simulta $>$. Citado na página 19.

ZABINSKI, J. S. et al. Stoichiometry and characterization of aluminum oxynitride thin films grown by ion-beam-assisted pulsed laser deposition. Thin Solid Films, v. 516, n. 18, p. 6215-6219, 2008. ISSN 00406090. Citado na página 6.

ZIEGLER, J. Serim-2003. Nuclear Instruments and Methods in Physics Research, Section B: Beam Interaction with Materials and Atoms, v. 2019, p. 1-10, 2004. ISSN 0168583X. Citado 2 vezes nas páginas 25 e 27. 